

\title{
LA ENSEÑANZA DE LAS FUENTES DE ENERGÍA RENOVABLES EN EDUCACIÓN SECUNDARIA
}

\section{TRABAJO DE FIN DE MÁSTER}



María Jesús Arrebola Miranda

Granada, Junio de 2014 


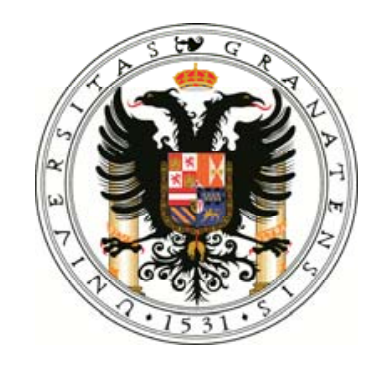

\section{UNIVERSIDAD DE GRANADA}

\section{MÁSTER UNIVERSITARIO DE PROFESORADO DE EDUCACIÓN} SECUNDARIA OBLIGATORIA Y BACHILLERATO, FORMACIÓN PROFESIONAL Y ENSEÑANZA DE IDIOMAS (ESPECIALIDAD BIOLOGÍA-GEOLOGÍA)

\section{TRABAJO DE FIN DE MÁSTER}

\section{LA ENSEÑANZA DE LAS FUENTES DE ENERGÍA}

\section{RENOVABLES EN EDUCACIÓN SECUNDARIA}

\begin{tabular}{|l|l|l|}
\hline \multicolumn{1}{|c|}{ La Autora } & V.B. Director & V.B. Director \\
\hline & & \\
& & \\
\hline Fdo.: Ma Jesús Arrebola Miranda & Fdo.: F. Javier Carrillo Rosúa & Fdo.: Ricardo Casas del Castillo \\
\hline
\end{tabular}




\section{ÍNDICE}

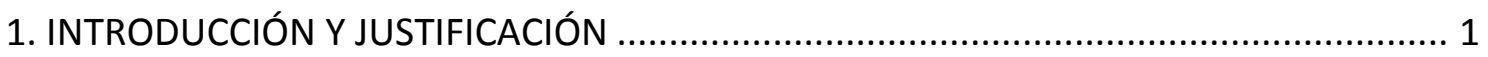

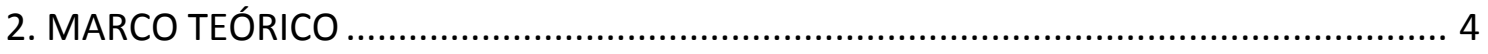

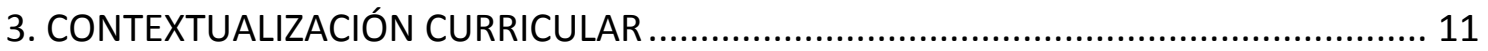

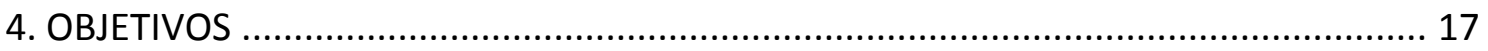

5. ANÁLISIS DE LIBROS DE TEXTO: MUESTRA Y METODOLOGÍA .................................. 18

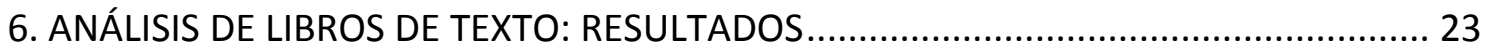

6.1. Resultados del análisis de contenidos.................................................. 23

6.2. Resultados del análisis de las imágenes .................................................. 28

6.3. Resultados del análisis de las actividades ............................................... 31

6.4. Resultados del análisis global............................................................ 34

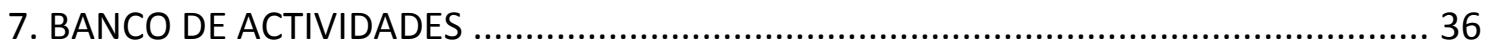

7.1. CONSTRUIMOS UNA CHIMENEA SOLAR.................................................... 37



7.3. ¿PARA QUÉ UTILIZARÍAS LA DESTILACIÓN SOLAR? ................................... 52

7.4. ¿RECURSO ENERGÉTICO ES IGUAL A CONFLICTO? .................................... 58

7.5. ¿CUÁNTA ENERGÍA HAY EN LA COMIDAD DE MARTA? ............................66

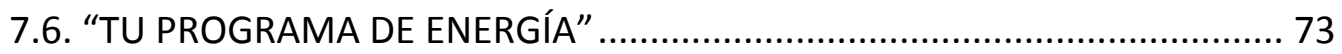

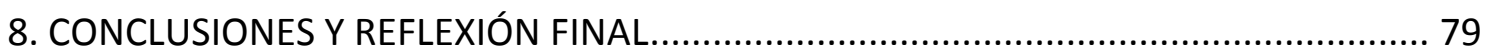

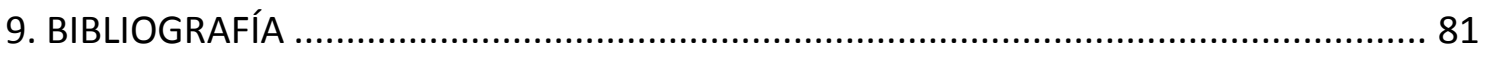



\section{ANEXOS}

ANEXO I: INSTRUMENTO DE ANÁLISIS Y RESULTADOS OBTENIDOS ..............................8 87

ANEXO II: RECURSOS DEL BANCO DE ACTIVIDADES ................................................ 100

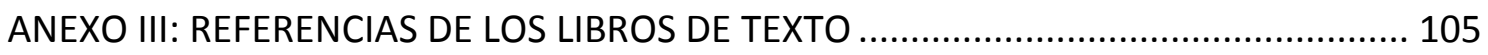




\section{INTRODUCCIÓN Y JUSTIFICACIÓN}

Según el IDAE las energías renovables son "las fuentes de abastecimiento energético más respetuosas con el medio ambiente. Son fuentes de abastecimiento inagotables, ya que en su origen proceden en su mayoría del Sol..." (Gómez, 2006).

En general, las fuentes de energía se clasifican en dos, fuentes de energía renovables y no renovables. Ambas se han estado utilizando a lo largo de toda la historia de la humanidad, desde los molinos de viento para moler el trigo, hasta el petróleo para el transporte o la obtención de energía eléctrica a partir de diversas fuentes. Pero cuando tratamos de fuentes de energía no renovables, no siempre se piensa en un problema de agotamiento, que hace algún tiempo parecía bastante lejano, pero que cada vez está más cerca si no se adoptan soluciones adecuadas y urgentes.

Hoy en día, en el empeño por abastecer todas las energéticas, principalmente de los países desarrollados, estamos destruyendo nuestro planeta. Pero, ¿̇hasta cuándo podemos seguir así? Tendemos a pensar que el Medio Ambiente no tiene límites y que todo lo que destruimos se regenera solo, sin ninguna consecuencia. La producción y el uso descontrolado de las fuentes de energía están provocando el agotamiento de los recursos energéticos, un aumento de las emisiones de $\mathrm{CO}_{2}$, y como consecuencia una aceleración del calentamiento global, lluvia ácida, problemas de salud, contaminación del agua del mar, accidentes nucleares, etc. Como dice la frase que hemos visto en algunos anuncios publicitarios: "La energía más limpia es la que no se consume".

Por tanto, hay que plantear una solución a esta problemática que muchos no son capaces de ver, comenzando por cambios de actitudes, que nos lleven a cambios de comportamiento, e intentando promover el desarrollo sostenible en el área de la energía. Estoy firmemente convencida de que uno de los pilares fundamentales de todo ello es la Educación. Pero, ¿qué se enseña al alumnado sobre las fuentes de energía?

He elegido este Trabajo de Fin de Máster porque me planteaba muchas cuestiones acerca de la enseñanza de las fuentes de energía renovables en Educación 
Secundaria. Por tanto, lo que pretendo es buscar respuesta a esas preguntas. Dada importancia que tienen los libros de texto siguen teniendo en la enseñanza de las ciencias (Perales y Vílchez, 2012), en primer lugar he considerado conocer cómo se aborda esta temática, qué contenidos se trabajan y sobre todo de qué forma. A través del análisis de libros de texto se pretende indagar en cuáles son los contenidos que se enseñan y con qué profundidad; ya sea una simple mención o una descripción más detallada y con aporte de datos concretos que permitan al alumnado adquirir los conocimientos y las competencias necesarios para la toma de decisiones en su día a día o en el futuro. Por otro lado, el análisis del número y calidad de las imágenes nos permite conocer a qué fuentes de energía se les dedica más atención. Por último, dado que las "actividades", tal como se confieren en los libros de texto, constituyen una de las principales herramientas didácticas que utiliza el profesorado y para que el alumnado adquiera y afiance sus conocimientos (pero también destrezas y actitudes), se ha realizado un análisis que tiene en cuenta su número y tipología.

En segundo lugar, con este TFM se pretende crear un banco donde se desarrollen actividades abordadas con un detalle y profundidad, en este sentido, generalmente diferentes a las planteadas en los libros de texto. Con esto no quiero decir que las de los éstos sean peores o que estén mal diseñadas. En las actividades que quiero desarrollar pretendo que el alumnado disfrute con lo que está realizando, que sean protagonista de su propio aprendizaje y, en la medida de lo posible, el profesor o profesora juegue un papel de guía en ese aprendizaje. Para ello se han desarrollado algunas, de carácter experimental, en las que el alumnado tendrá que hacer sus propios diseños. Otras responden a la filosofía Ciencia Tecnología Sociedad (CTS), ya que, de acuerdo con Domenech et al. (2003), la atención a las interacciones entre ciencia, Tecnología y Sociedad tienen que ser un aspecto esencial en la enseñanza de las fuentes de energía y el ahorro energético para formar alumnos y alumnas para que sean capaces de comprender el mundo en el que viven y puedan adoptar actitudes responsables. Se ha pretendido, pues, plantear actividades cuya metodología responda al aprendizaje basado en problemas (A.B.P.). De esta forma, el alumnado, además de adquirir conocimientos, adquiere habilidades y actitudes. 
Además se ha introducido la utilización de la Tecnologías de la Información y la Comunicación en el desarrollo de todas ellas.

Se ha elegido segundo curso de Educación Secundaria Obligatoria (ESO), tanto para el análisis de libros de texto como para el desarrollo de actividades, porque según el Real Decreto 1631/2006, por el que se establecen las enseñanzas mínimas correspondientes a la Educación Secundaria Obligatoria, es en éste donde se trabajan los contenidos de las fuentes de energía y el ahorro energético de una manera explícita dentro de la ESO. Además esto permitía poder utilizar, para el desarrollo de las actividades, contenidos tanto del área de Física y Química como de Biología y Geología, puesto que en este curso se encuentran de forma conjunta con el nombre de Ciencias de la Naturaleza. 


\section{MARCO TEÓRICO}

En el ámbito de las Ciencias de la Naturaleza existen numerosos trabajos en los que lleva a cabo un análisis de algunos de los aspectos relacionados con la enseñanza/aprendizaje de la energía en la Educación Secundaria Obligatoria, pero son relativamente escasos los que se centran en las fuentes de energía, y más concretamente, en las fuentes de energías renovables.

Según Herbel, Siracusa y Raviolo (2000): "tres medios están disponibles para cuidar la energía: tecnológico, económico y social. El tecnológico involucra el diseño de construcciones, aparatos y sistemas eficientes en el manejo de la energía. La política de precios es el medio económico para promover el cuidado de la energía. En lo social, la conservación de la energía se promueve desde el uso de la persuasión, información y normas comunitarias para cambiar actitudes y conductas. La educación contribuye en el medio social; sin embargo, no es un tema ampliamente enseñado en la escuela."

"Energy Literacy" [1] es un reciente proyecto (2012) de alfabetización científica, realizado por el "U.S. Department of Energy", que pretende enseñar el rol que tiene la energía en el universo y en nuestras vidas. Propone siete Principios Esenciales, amplias categorías que representan "grandes ideas". Similares iniciativas de alfabetización científica se han desarrollado en relación con otras temáticas (e.g. Earth Science Literacy Initiative, Pedrinaci, 2011) y probablemente surjan más en el futuro. Cada uno de ellos está apoyado por un número variable de Conceptos Fundamentales (entre 6 y 8). Estos Principios Esenciales son los siguientes:

1. La energía es una magnitud física que obedece unas leyes naturales precisas.

2. Los procesos físicos en la Tierra son el resultado del flujo de energía a través del sistema terrestre.

3. Los procesos biológicos dependen del flujo de energía a través del sistema terrestre.

4. Diversas fuentes de energía se pueden utilizar para las actividades humanas, y con frecuencia esa energía debe ser transferida desde la fuente hasta el destinatario. 
5. Las decisiones energéticas están influenciadas por factores económicos políticos, medioambientales y sociales.

6. La cantidad de energía utilizada por la sociedad humana depende de muchos factores.

7. Las opciones energéticas afectan a la calidad de vida de los individuos y las sociedades.

Cuando hablamos de alfabetización científica no se trata de que el alumnado conozcan multitud de conceptos o datos para memorizar, sino de proporcionarles las herramientas adecuadas para que comprendan cuál es la realidad actual y que sean capaces de involucrarse en la toma de decisiones. De acuerdo con Sabariego y Manzanares (2006), la alfabetización científica debe ser un proceso, como los autores llaman, de investigación orientada "que superando el reduccionismo conceptual permita a los alumnos participar en una aventura científica de enfrentarse a problemas relevantes y reconstruir los conocimientos científicos, que habitualmente la enseñanza transmite elaborados". De esta forma se favorecería el aprendizaje significativo ${ }^{1}$, ya que el alumnado relacionaría de forma más eficiente los conocimientos previos, sus experiencias cotidianas, con los nuevos que van adquiriendo.

No solo hay que tratar la temática de las fuentes de energía como conocimientos, como contenidos conceptuales que se deben adquirir en el aula, sino que hay que conseguir que haya una conciencia sobre el problema, es decir, la adquisición de unas actitudes, en todos los ciudadanos y ciudadanas. Por ello, la mejor herramienta que tenemos es una educación que se preocupe también de los valores. Tal y como dice Gómez (2006) en su artículo: "Educándonos y educando seremos capaces de que los individuos y las comunidades adquiramos conciencia de nuestro medio, y aprendamos los conocimientos, las destrezas, la experiencia y también la determinación que nos capacite para actuar, individual y colectivamente en la resolución de los problemas ambientales presentes y futuros. Por ello, nuestro primer lugar de actuación debe de ser la escuela".

\footnotetext{
${ }^{1}$ Es el aprendizaje en el cual el sujeto relaciona sus conocimientos previos con los nuevos dotándolos así de coherencia respecto a sus estructuras cognitivas (apuntes de la asignatura "Aprendizaje y desarrollo de la personalidad").
} 
Sabemos que la energía es un tema que hay que tratar en la escuela, pero nos planteamos la misma cuestión que García, J. E., Rodríguez, F., Solís, M. C., y Ballenilla, F. (2007): ¿Hay un adecuado tratamiento de la temática de la energía desde los primeros niveles? "En muchas ocasiones se trabaja la energía como un concepto físico, desvinculado de los problemas socioambientales, en otras, y ya en el ámbito de la Educación Ambiental, recibe un tratamiento muy simplificador. En el primer caso, el profesorado se limita a definir algunos conceptos físicos, a hablar de diferentes formas de energía o a trabajar someramente el papel de la energía en el funcionamiento de nuestra sociedad. En el segundo, lo habitual, es presentar un discurso sobre las energías alternativas y el ahorro energético, centrado en el mesocosmos y lo local, que no suele profundizar en las cuestiones sociales y ecológicas de fondo, y que ayuda poco a una comprensión más compleja del tema".

Rodríguez y García (2007) analizaron doce materiales didácticos con un total de 80 actividades para trabajar la energía. Estos autores concluyeron que la mayoría de las actividades se refieren a la descripción de fuentes de energía y de tipos de usos energéticos, así como a problemas asociados al consumo doméstico, mientras que el número de actividades que sí intentan una aproximación más global y compleja al tema de la energía son mucho menos numerosas.

García et al. (2007) proponen, para solventar la falta de conexiones entre los contenidos y la perspectiva simplificadora que se le da al tratamiento de la problemática de la energía en la docencia, la elaboración de "redes de contenidos" y la consideración de varios niveles de formulación de cada problema, desde los más simples a los más complejos. Para ello los autores proponen, en primer lugar, considerar todas las posibles variables, elementos y relaciones que estén implicados en la problemática que se va a trabajar, y en segundo lugar adoptar una "perspectiva integradora", lo que supone:

Integrar los aspectos naturales con los sociales, evitando los planteamientos reduccionistas.

Integrar la ciencia con las actitudes y valores. 
- Integrar los diferentes tipos de conocimientos (conceptual, procedimental y actitudinal) entre sí y con la acción.

Integrar lo local con lo global, lo concreto con lo general.

Existen numerosos factores a tener en cuenta en la enseñanza/aprendizaje de la energía en la ESO. Entre ellos cabe destacar la gran relación que existe entre los libros de texto y las ideas previas que tiene el alumnado sobre numerosos conceptos. Bañas, Mellado y Ruíz (2004) realizaron un estudio sobre la relación que tenía el tratamiento dado por los libros de texto al tema de la energía con las ideas que presentaban los alumnos y alumnas. La metodología que emplearon fue el análisis de los datos recogidos a través de un cuestionario con preguntas de diferentes fuentes, realizado por un total de 250 alumnos y alumnas de primer ciclo de Educación Secundaria Obligatoria. Además, analizaron cinco libros de texto de distintas editoriales. Este estudio permitió comprobar que aunque son muchos los factores que intervienen en el proceso de enseñanza/aprendizaje, sí que había una gran coincidencia entre las ideas alternativas del alumnado y el tratamiento que se daba al tema de la energía en los libros de textos.

Otro factor importante es la percepción del profesorado sobre la energía. El pensamiento del profesorado configura a éstos como unos profesionales reflexivos cuyas decisiones, rutinas y creencias, desarrolladas en el ejercicio de la práctica docente, generan un cuerpo de conocimiento específico (Vázquez, 1994). Este autor analizó las ideas sobre la energía, su uso y las tecnologías de producción y consumo, de los profesores de ciencias en formación inicial, utilizando para ello un cuestionario de 22 ítems con cinco subescalas, donde cada cuestión establecía una afirmación sobre un aspecto relevante sobre la energía. El cuestionario fue contestado por estudiantes de un curso de formación inicial para profesorado de Secundaria, los cuales eran licenciados en distintas especialidades. De acuerdo con este estudio las ideas y el pensamiento del profesor influyen y determinan la forma y la calidad de su enseñanza. Pero, en mi opinión, muchas de las ideas previas concluidas en el mismo serían muy diferentes si se realizara en la actualidad, puesto que hoy en día existe otro tipo de valores y actitudes respecto a este tema. Algunas de las ideas previas y dificultades de aprendizaje obtenidas en el mencionado estudio fueron: 
- No es cierto que las políticas energéticas son determinadas por multitud de decisiones individuales.

- No sabe que el gas ahorra más energía que la electricidad en la calefacción.

- Las cocinas eléctricas son mejores que las de gas por contaminar menos.

- El motor de un coche puede ser mejorado hasta usar toda la energía de la gasolina.

- Las centrales térmicas pueden mejorarse para convertir casi toda la energía del combustible.

- No sabe que las nuevas tecnologías consumen mucha energía.

- No cree que haya relación entre bajo consumo de energía y el producto y pobreza de un país.

Çoker, B., Çatlıoğlu, H., y Birgin, O. (2010) realizaron un estudio a estudiantes de Primaria y Secundaria de Turquía para conocer sus conocimientos sobre las fuentes de energía y cómo variaban con el nivel del alumnado. El instrumento utilizado fue un cuestionario de respuestas abiertas para que los estudiantes pudieran expresar sus conocimientos sin límites. Los alumnos y alumnas de Primaria determinaron que la electricidad es una fuente de energía, y también los de mayor edad, aunque en un porcentaje reducido. Tanto los de Primaria como de Secundaria definieron las baterías como una fuente de energía renovable. En general, la mayoría del alumnado consideraba el Sol como la principal fuente de energía para mantener la vida en la Tierra, y los de Primaria incluían el agua y el aire como segunda y tercera fuentes, respectivamente. El estudio pretende no solo dar una visión de la importancia que tiene introducir o profundizar sobre conceptos relacionados con la energía en la escuela, sino insistir en la necesidad de un aprendizaje basado en la combinación del contexto escolar con aplicaciones prácticas, experiencias y proyectos basados en la vida real.

Kishore y Kisiel (2013) diseñaron un cuestionario con preguntas de opción múltiple y preguntas de respuesta abierta para conocer las diferentes percepciones sobre energía solar y células fotovoltaicas de los estudiantes de Secundaria en un instituto de California. El estudio permitió conocer que aunque el alumnado estaba 
familiarizado con el tema, habían adquirido algunos conceptos erróneos. Las explicaciones de los estudiantes fueron:

- Las células fotovoltaicas están compuestas de electrones, y cuando los rayos solares los golpean, algunos se liberan.

- Los electrones liberados empiezan a activarse y esto genera energía. Ésta se extrae de los paneles mediante cables y se lleva a cajas donde se convierte en electricidad.

- Se alimentan de la energía solar, que emite electricidad.

- Recogen la luz solar y convierten su calor en energía.

- Absorben luz y calor solar.

- Los paneles almacenan los rayos solares y lo usan después como energía.

- Producen energía (sin ninguna explicación adicional).

- Las células fotovoltaicas del panel solar absorben luz y calor, y éstos provocan reacciones químicas en las celdas, como las baterías. Esto produce electricidad. Asimilan la energía del Sol (en general, sin ninguna clarificación adicional).

Zyadin, A., Puhakka, A., Ahponen, P., Cronberg, T., y Pelkonen, P. (2012) realizaron un estudio para investigar los conocimientos, actitudes y percepciones de los estudiantes de Jordania sobre las energías renovables. Diseñaron un cuestionario con tres tipos de preguntas realizado a un total de 617 estudiantes de colegios rurales y urbanos. Estos determinaban con precisión la energía solar y eólica como fuentes de energías renovables, pero empezaban a tener más dudas, por ejemplo, con la energía geotérmica. Identificaban de forma errónea el gas natural. Según los autores, esto podría deberse a la falta de información e incluso a la palabra "natural", que podría crear confusión. Existían variaciones en los resultados, dependiendo del tipo de escuela, el nivel de educación de los padres o incluso la orientación religiosa. Sin embargo, independientemente de estos determinantes, en general el $53 \%$ de todos los encuestados estaba de acuerdo con seguir importando petróleo y gas.

En general, la mayoría de los estudios consultados ofrecen una visión de las ideas previas, conocimientos, percepciones y actitudes que tiene el alumnado sobre las fuentes de energía y el ahorro energético, así como las del profesorado o los futuros 
docentes y la relación que tienen los libros de texto con éstas. Otros estudios analizados aportan nuevos mecanismos para la enseñanza/aprendizaje de esta temática, diferente a la llevada a cabo tradicionalmente, donde lo más importante no son sólo los conocimientos teóricos sino integrarlos con los aspectos sociales, valores y actitudes, debido a la importancia que tiene tanto por las pequeñas acciones en la vida cotidiana como para formar a los que en un futuro serán los que tomen las decisiones en cuestiones energéticas. 


\section{CONTEXTUALIZACIÓN CURRICULAR}

Para la realización del Trabajo fin de Máster se ha tenido en cuenta el marco legislativo que regula las enseñanzas mínimas correspondientes a la Educación Secundaria Obligatoria dentro de la Ley Orgánica 2/2006, de 3 de mayo.

En el anexo II del Real Decreto 1631/2006, de 29 de diciembre, por el que se establecen las enseñanzas mínimas correspondientes a la Educación Secundaria Obligatoria, se establece: "Ia educación secundaria obligatoria ha de facilitar a todas las personas una alfabetización científica que haga posible la familiarización con la naturaleza y las ideas básicas de la ciencia y que ayude a la comprensión de los problemas a cuya solución puede contribuir el desarrollo tecnocientífico, facilitando actitudes responsables dirigidas a sentar las bases de un desarrollo sostenible".

Para el presente TFM, se ha decidido tomar como referencia el curso de 20 de E.S.O. tanto para el análisis de libros de texto como para el planteamiento de actividades, de acuerdo con los contenidos del Real Decreto 1631/2006, de 29 de diciembre, donde se enmarca las fuentes de energía y el ahorro energético. No obstante, las actividades que se van a proponer en el banco de actividades del TFM, con la consiguiente adaptación también podrían ser utilizadas en otros cursos y otras materias en la Educación Secundaria. Como por ejemplo en 3ํ ESO en la asignatura de Biología y Geología dentro del bloque 6. Las personas y el Medio Ambiente o en 4으 ESO en la asignatura de Física y Química dentro del bloque 5. La contribución de la ciencia a un futuro sostenible.

Los objetivos generales de la materia de Ciencias de la Naturaleza según el Real Decreto $1631 / 2006$, que se pretenden alcanzar en las actividades planteadas en el banco de actividades del presente TFM, son los siguientes:

1. “Comprender y utilizar las estrategias y los conceptos básicos de las ciencias de la naturaleza para interpretar los fenómenos naturales, así como para analizar y valorar las repercusiones de desarrollos tecnocientíficos y sus aplicaciones". 
2. "Aplicar, en la resolución de problemas, estrategias coherentes con los procedimientos de las ciencias, tales como la discusión del interés de los problemas planteados, la formulación de hipótesis, la elaboración de estrategias de resolución y de diseños experimentales, el análisis de resultados, la consideración de aplicaciones y repercusiones del estudio realizado y la búsqueda de coherencia global".

3. "Comprender y expresar mensajes con contenido científico utilizando el lenguaje oral y escrito con propiedad, interpretar diagramas, gráficas, tablas y expresiones matemáticas elementales, así como comunicar a otros argumentaciones y explicaciones en el ámbito de la ciencia".

4. "Obtener información sobre temas científicos, utilizando distintas fuentes, incluidas las tecnologías de la información y la comunicación, y emplearla, valorando su contenido, para fundamentar y orientar trabajos sobre temas científicos".

5. "Adoptar actitudes críticas fundamentadas en el conocimiento para analizar, individualmente o en grupo, cuestiones científicas y tecnológicas".

7. “Comprender la importancia de utilizar los conocimientos de las ciencias de la naturaleza para satisfacer las necesidades humanas y participar en la necesaria toma de decisiones en torno a problemas locales y globales a los que nos enfrentamos".

8. "Conocer y valorar las interacciones de la ciencia y la tecnología con la sociedad y el medio ambiente, con atención particular a los problemas a los que se enfrenta hoy la humanidad y la necesidad de búsqueda y aplicación de soluciones, sujetas al principio de precaución, para avanzar hacia un futuro sostenible".

En el desarrollo de las actividades se trabajan los contenidos establecidos en el anexo II del Real Decreto, relativo a las Materias de Educación Secundaria Obligatoria concretamente en el bloque 1 y bloque 2 del 2 o curso de la asignatura de Ciencias de la Naturaleza. 
Contenidos comunes:

- Familiarización con las características básicas del trabajo científico, por medio de: planteamiento de problemas, discusión de su interés, formulación de conjeturas, diseños experimentales, etc., para comprender mejor los fenómenos naturales y resolver los problemas que su estudio plantea.

- Utilización de los medios de comunicación y las tecnologías de la información y la comunicación para obtener información sobre los fenómenos naturales.

- Interpretación de información de carácter científico y utilización de dicha información para formarse una opinión propia y expresarse adecuadamente.

- Reconocimiento de la importancia del conocimiento científico para tomar decisiones sobre los objetos y sobre uno mismo.

- Utilización correcta de los materiales e instrumentos básicos de un laboratorio y respeto por las normas de seguridad en el mismo.

Bloque 2. Materia y Energía:

- Valoración del papel de la energía en nuestras vidas.

- Análisis y valoración de las diferentes fuentes de energía, renovables y no renovables.

- Problemas asociados a la obtención, transporte y utilización de la energía.

- Toma de conciencia de la importancia del ahorro energético.

El criterio de evaluación para evaluar al alumnado con el desarrollo de las actividades según el Real Decreto 1631/2006 es:

1. "Utilizar el concepto cualitativo de energía para explicar su papel en las transformaciones que tienen lugar en nuestro entorno y reconocer la importancia y repercusiones para la sociedad y el medio ambiente de las diferentes fuentes de energía renovables y no renovables.

Tal y como dice el Real Decreto: "se pretende evaluar si el alumnado relaciona el concepto de energía con la capacidad de realizar cambios, si conoce diferentes formas y fuentes de energía, renovables y no renovables, sus ventajas e inconvenientes y algunos de los principales problemas asociados a su obtención, transporte y utilización. 
Se valorará si el alumnado comprende la importancia del ahorro energético y el uso de energías limpias para contribuir a un futuro sostenible".

Asimismo en el Real Decreto se habla de la importancia de la contribución de las Ciencias de la Naturaleza en la adquisición de las competencias básicas. Cuando se refiere a la adquisición de la competencia en el conocimiento y la interacción con el mundo físico, se dice: "... familiarización con el trabajo científico, para el tratamiento de situaciones de interés ... elaboración de estrategias para obtener conclusiones, incluyendo, en su caso, diseños experimentales, hasta el análisis de los resultados". Además de "... evitar situaciones simplistas de exaltación o de rechazo del papel de la tecnociencia, favoreciendo el conocimiento de los grandes problemas a los que se enfrenta hoy la humanidad, la búsqueda de soluciones para avanzar hacia el logro de un desarrollo sostenible y la formación básica para participar, fundamentadamente, en la necesaria toma de decisiones en torno a los problemas locales y globales planteados."

En las actividades planteadas, se desarrolla, en primer lugar, la competencia en el conocimiento y la interacción con el mundo físico. Pero también se favorece la adquisición del resto de competencias como:

CB1. Competencia en comunicación lingüística: Esta competencia se desarrolla porque deben expresar, tanto oral como por escrito, y comprender el lenguaje científico, así como saber comunicarse adecuadamente durante el desarrollo y exposición de las actividades.

CB2. Competencia matemática. Se desarrolla en las actividades en las que se les plantea realizar cálculos, o manejar, interpretar y representar datos en gráficas.

CB4. Tratamiento de la información y competencia digital. Los alumnos y alumnas deben buscar, obtener y procesar información científica. Así como hacer uso de herramientas informáticas.

CB5. Competencia social y ciudadana. Se desarrolla esta competencia, puesto que el alumnado debe tomar decisiones cuando estén trabajando en grupo y elegir cómo comportarse en determinadas situaciones. El alumnado, en algunas de las 
actividades planteadas debe "utilizar el juicio moral para elegir y tomar decisiones, y ejercer activa y responsablemente los derechos y deberes de la ciudadanía"

CB6. Competencia cultural y artística. Se desarrolla en algunas actividades en las cuales deben "poner en funcionamiento la iniciativa, la imaginación y la creatividad para expresarse mediante códigos artísticos".

CB8. Autonomía e iniciativa personal. Los alumnos y alumnas deben cooperar y trabajar en equipo durante el desarrollo de la actividad. Así como relacionarse, cooperar y valorar las ideas de los demás.

Además se ha tenido en cuenta, la Orden de 10 de Agosto del 2007, por la que se desarrolla el currículo correspondiente a la Educación Secundaria en Andalucía. En ella se dice: "el alumnado debe también tomar conciencia de los diversos factores científicos y tecnológicos, sociales, políticos, económicos, culturales, éticos, etc., que influyen en el planteamiento y solución de esos problemas, así como de la necesidad de observar comportamiento y mantener actitudes que ayuden a lograr un futuro sostenible", siendo este el principal objetivo que se pretende alcanzar en el desarrollo de algunas de las actividades planteadas en el presente TFM.

Las actividades planteadas se enmaran, en la Orden, dentro del área de Ciencias de la Naturaleza en los núcleos temáticos: 4. El uso responsable de los recursos naturales y más concretamente el 5 . La crisis energética y sus posibles soluciones.

Dentro del núcleo temático "el uso responsable de los recursos naturales" se plantean una serie de contenidos y problemáticas relevantes que se deben tratar en el aula y entre ellas, se encuentra los problemas del agua y las medidas para solucionarlo, así como los problemas con otros recursos naturales como las fuentes de energía. Ambos son planteados en algunas actividades y tal como propone la Orden relacionándolos unos con otros.

Por otro lado, en el núcleo temático "la crisis energética y sus posibles soluciones" nos dice que debido a la situación de consumo de petróleo y sus derivados en Andalucía y la producción de combustibles fósiles escasa, "se hace, por tanto necesario seguir fomentando el uso de fuentes de energía renovables y, en el ámbito 
educativo, concienciar al alumnado de la necesidad de ahorrar energía siempre que sea posible...". Los contenidos y problemáticas relevantes que se plantean son las siguientes:

- En relación con el problema energético, en general, y con las medidas que se proponen para solucionarlo.

- En relación con el ahorro energético.

- En relación con las fuentes de energía.

Cada uno de ellos con una serie de cuestiones tales como, ¿para qué actividades de las que realizamos cotidianamente necesitamos energía?, ¿cómo se distribuye la energía?, ¿qué fuentes alternativas podrían utilizarse para sustituir a los combustibles fósiles?, etc. y que se han trabajado en las diversas actividades que se proponen en el banco de actividades del presente TFM. 


\section{OBJETIVOS}

Los objetivos que se pretenden alcanzar con la realización de este trabajo se refieren por un lado al análisis de los libros de texto, y por otro al diseño de actividades.

El objetivo planteado en relación con el estudio de los libros de texto de segundo curso de la ESO, según normativa LOE, sería el siguiente:

* Analizar los contenidos sobre fuentes de energía en relación con el texto, las imágenes y las actividades propuestas.

Este objetivo, a su vez, se puede concretar abordando los siguientes objetivos de carácter más específico:

1. Cuantificar el espacio dedicado a los contenidos sobre fuentes de energía como medida de su importancia.

2. Enumerar las fuentes de energía que se abordan.

3. Identificar las ideas previas o errores que se presentan o pueden transmitir.

4. Establecer las críticas que se plantean con respecto al uso de los combustibles fósiles.

5. Determinar si se trabaja el ahorro energético y cuánto se profundiza en el mismo.

6. Caracterizar las imágenes por su contenido y tipología.

7. Caracterizar las actividades por su tipología.

El objetivo que se pretenden alcanzar en relación con el diseño de actividades en el presente TFM es:

1. Diseñar actividades de distinta tipología y características incluyendo los trabajos prácticos, con enfoque CTS o de aprendizaje basado en problemas. 


\section{ANÁLISIS DE LIBROS DE TEXTO: MUESTRA Y METODOLOGÍA}

Para el análisis de los libros de texto sobre las fuentes de energía y el ahorro energético, se han elaborado ad hoc una herramienta de análisis consistente en tres tablas de doble entrada; una para los contenidos (texto), otra para las imágenes y otra para las actividades con 30, 20 y 17 ítems, respectivamente. Esta herramienta, que se puede consultar en el anexo I, se ha aplicado al estudio de 8 libros de texto de segundo curso de Educación Secundaria Obligatoria, correspondiente a la asignatura de Ciencias de la Naturaleza, editados entre 2008 y 2012, es decir, bajo normativa LOE. Aunque solo esté representada una parte de las distintas editoriales, se considera que las utilizadas son una muestra lo suficiente representativas del mercado español, de hecho son mayoritarias, para cumplir los objetivos que se persiguen. La mayoría de dichos libros de texto proceden de la biblioteca de la Facultad de Ciencias de la Educación de la Universidad de Granada.

En las tablas de contenidos (Anexo 1, Tablas II a VI) se han analizado los siguientes ítems: el número de páginas totales del libro, el número de páginas del tema (sin incluir las actividades finales) y el número de páginas que se dedican tanto a las fuentes de energía como al ahorro energético. Con el objeto de poder realizar adecuadamente un análisis cuantitativo, se han añadido dos variables con las proporciones de páginas que se dedican a esta temática respecto al total del libro y respecto al tema. Además se ha contabilizado el número de temas totales y el número del tema en el que se trabajan las fuentes de energía.

Por otra parte, se han extraído las ideas previas, tomando como referencia las obtenidas de diferentes estudios realizados, y errores conceptuales que en ocasiones aparecen los libros. Para proceder a su clasificación y análisis, se han enumerado de la siguiente manera:

- " 1 " El Hidrógeno es una fuente de energía.

. "2" La electricidad es una fuente de energía (Coker et al., 2010).

- "3" Las baterías son una fuente de energía (renovable) (Coker et al., 2010).

- " 4 " Confunde la energía solar térmica con la solar fotovoltaica. 
- " 5 " No sabe que el gas ahorra más energía que la electricidad en la calefacción (Vázquez, 1994).

- "6" Los aparatos eléctricos (ej.: cocinas, calefacciones) siempre contaminan menos que los que utilizan otras energías (ej.: gas) (Vázquez, 1994).

- "7" El motor de un coche puede ser mejorado hasta usar toda la energía de la gasolina (Vázquez, 1994).

- "8" Las centrales térmicas pueden mejorarse para convertir casi toda la energía del combustible en electricidad (Vázquez, 1994).

- " 9 " Las células fotovoltaicas se alimentan de la energía solar, que emite electricidad (Kishore y Kisiel, 2013).

- "10" Las células fotovoltaicas recogen la luz solar y convierten su calor en energía (Kishore y Kisiel, 2013).

- "11" Los paneles almacenan los rayos solares y lo usan después como energía (Kishore y Kisiel, 2013).

- "12" Las células fotovoltaicas del panel solar absorben luz y calor, y éstos provocan reacciones químicas en las celdas, como las baterías. Esto produce electricidad (Kishore y Kisiel, 2013).

. "13" Los biocombustibles son una fuente de energía renovable 2 .

Posteriormente se han analizado los tipos de fuentes de energía y vectores energéticos que se presentan en los libros de texto. Estos se han clasificado distinguiendo, por un lado, las fuentes de energía no renovables; carbón, petróleo, gas (dividido en dos: gas natural "convencional" y gas procedente del fracking ${ }^{3}$ ) y la

\footnotetext{
${ }^{2}$ Aclárese que los biocombustibles son productos energéticos obtenidos tras producirse una transformación química o biológica de la biomasa. Por consiguiente, la biomasa es la fuente de energía renovable y no los biocombustibles.

${ }^{3}$ Fracking es un término inglés que hace mención a la técnica de fracturación hidráulica, utilizada para extraer gas no convencional procedente del subsuelo, la cual está ocasionando muchas disputas por si existe riego o no de dañar el Medio Ambiente. En el doble artículo de Nature titulado "Natural gas: should fracking stop?" (2011), se plantean ambas posturas. Por un lado, los autores Howart y Ingraffea afirman el alto riesgo que conlleva la técnica utilizada en las última década, en la cual se inyecta agua con arena y aditivos químicos a presión para que se fracture la roca, mientras que el autor Engelder defiende la postura contraria afirmando que el gas natural puede ayudar a disminuir el calentamiento global sustituyendo el carbón por el gas natural procedente del fracking, además de que sería necesario para abastecer la gran demanda de recursos energéticos provocada por el crecimiento global de la población.
} 
energía nuclear, también dividida en dos, procedente de la fusión ${ }^{4}$ y de la fisión. Por otro lado, las fuentes de energías renovables, donde se incluye, la energía solar (dividida en térmica y fotovoltaica), eólica, biomasa, geotérmica, hidráulica y la marítima (dividida en mareomotriz y otras). Además se ha tenido en cuenta uno de los vectores energéticos, el Hidrógeno, lo que suma un total de 14 ítems sobre los distintos tipos de fuentes de energía y vectores energéticos. A cada uno de los ítems se les ha asignado una valoración numérica. De manera que se le da el valor de " 0 " si no aparece, "1" si aparece con una breve definición y "2" en caso que se aporte más información, como por ejemplo, usos, datos numéricos o las ventajas e inconvenientes.

Con el fin de realizar un análisis más completo y que no solo se preste atención a la parte conceptual de los contenidos, se han añadido algunos ítems para realizar una valoración de la parte actitudinal. Por un lado, se ha incluido un ítem para conocer si se hace alusión al ahorro energético en los libros de texto asignándole un valor de " 0 " si no aparece y "1" si aparece. Además se ha incluido otra columna, donde se hace referencia a si existe algún apartado concreto en el libro dedicado a concienciar al alumnado en cuanto a temas energéticos, como por ejemplo soluciones para un desarrollo sostenible, el futuro de la energía, problemas ambientales relacionados con la energía, etc., asignándole un valor de " 0 " si no aparece y "1" si aparece. Se ha añadido otro ítem sobre la crítica a los combustibles fósiles con tres subítems a considerar: "se van a agotar"; "contaminan" y "emiten $\mathrm{CO}_{2}$ a la atmósfera que contribuye al calentamiento global", dándole el valor de " 0 " si no aparece y " 1 " si aparece.

Para concluir la parte actitudinal de los contenidos, se ha añadido un ítem sobre el límite del petróleo dividido en dos subítems: por un lado se pretende conocer si se establece una fecha al agotamiento del petróleo con una valoración de " 0 " si no se establece, " 1 " si se establece de una manera absoluta y " 2 " si se establece de una manera condicionada, considerando las reservas actuales, que pueden ser ampliadas.

\footnotetext{
${ }^{4}$ Nótese que la energía de fusión es renovable. Sin embargo, se ha incluido en este apartado por constituir una alternativa (renovable e ilimitada) a la de fisión. Pensamos que de esta manera pueden compararse entre sí mejor que si las separamos en apartados distintos.
} 
El segundo subítem, años que quedan hasta su agotamiento, se rellenaría en caso de que la respuesta anterior sea " 1 " o " 2 ".

La segunda tanda de tablas de doble entrada (Anexo I, Tablas VII a XI) hacen referencia al análisis de las imágenes sobre las fuentes de energía en los libros de texto. Se ha tenido en cuenta, por un lado, el número de imágenes totales sobre fuentes de energía, y más específicamente, se ha contabilizado cuántas corresponden a fuentes de energías no renovables y cuántas a fuentes de energías renovables. Se ha calculado, para cada tipo, tanto el número como la proporción respecto al total de imágenes. Todo esto se ha analizado para los 14 tipos de fuentes de energía y vectores energéticos descritos anteriormente, dándole un valor de " 0 " si no aparece, " 1 " si aparece una imagen ilustrativa ${ }^{5}$ " 2 " si aparece una imagen explicativa ${ }^{6}$.

La tercera tanda de tablas de doble entrada (Anexo I, Tablas XII a XVI) se fija en el análisis de las actividades (tareas que se pregunta o encomienda realizar al alumnado) que se presentan en el tema. Se ha incluido un ítem para el número de actividades totales del tema, otro para el número de actividades sobre fuentes de energía y ahorro energético y otro para la proporción. Además se ha estudiado el tipo de actividades que se incluyen en los libros de texto sobre esta temática. Para ello se ha adoptado la clasificación que aparece en la Figura 1:

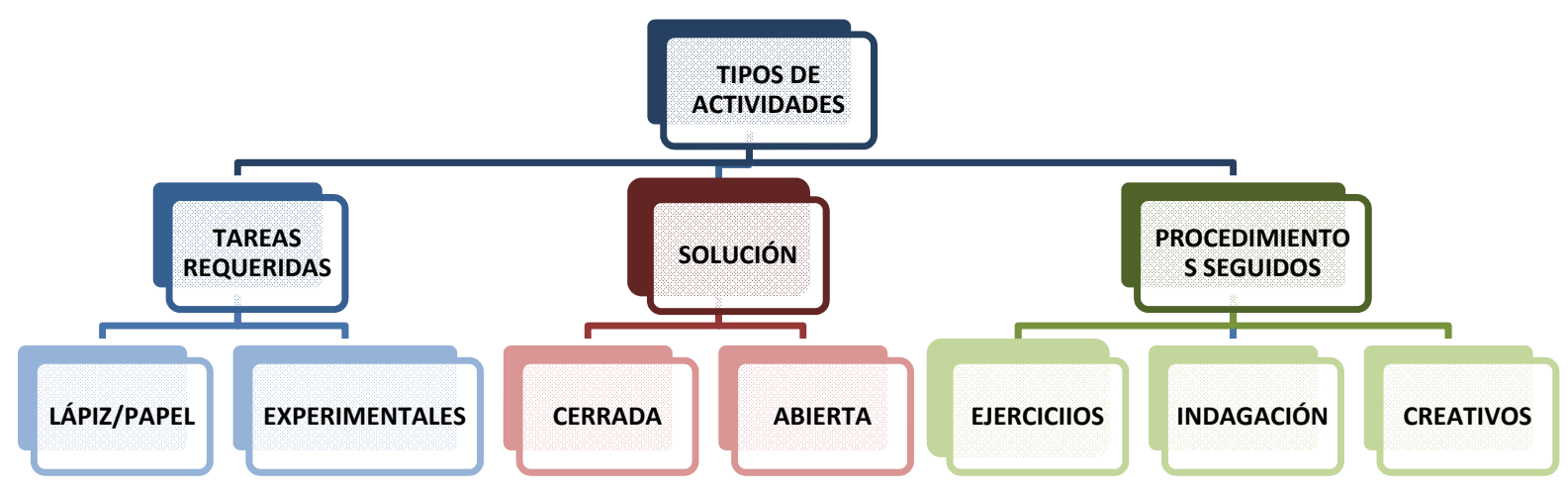

Fig.1. Tipos de actividades

\footnotetext{
${ }^{5}$ Muestra una visión de algún contenido del libro de texto pero no aporta más información. (ej.: imagen de una central nuclear).

${ }^{6}$ Ayuda a aclarar algún contenido del libro de texto y aporta más información (ej.: imagen de una central nuclear indicando sus partes).
} 
Para cada uno de estos tipos, que corresponde a tres clasificaciones de las actividades, se ha calculado tanto el número de actividades como la proporción respecto al total de actividades referentes a las fuentes de energía y el ahorro energético. 


\section{ANÁLISIS DE LIBROS DE TEXTO: RESULTADOS}

Para el estudio estadístico se han analizado los distintos ítems, tanto de los contenidos e imágenes como de las actividades. Posteriormente se han definido y calculado unos índices para evaluar cada bloque por separado. Finalmente, éstos se han utilizado para obtener un índice global de todo el análisis de cada libro, obteniendo valores para cada una de las editoriales.

\subsection{Resultados del análisis de contenidos}

En cuanto a la proporción de páginas dedicadas a las fuentes de energía y el ahorro energético respecto al número total del libro y respecto a cada tema, se puede observar en la Figura 2 que existe entre ambas una relación de proporcionalidad directa. Cuanto mayor es la proporción respecto al total, mayor es también la proporción respecto al tema. Excepciones a esta tendencia son los libros de Akal, Oxford y Elzevir, en los cuales hay una proporción elevada de páginas dedicadas a las fuentes de energía y ahorro energético respecto al total, pero no tanto respecto al tema. Esto no quiere decir que traten menos o peor la temática (de hecho son tres de los libros que le dedican más páginas), sino que también son los libros con los temas más extensos, lo cual da lugar a unos porcentajes menores.

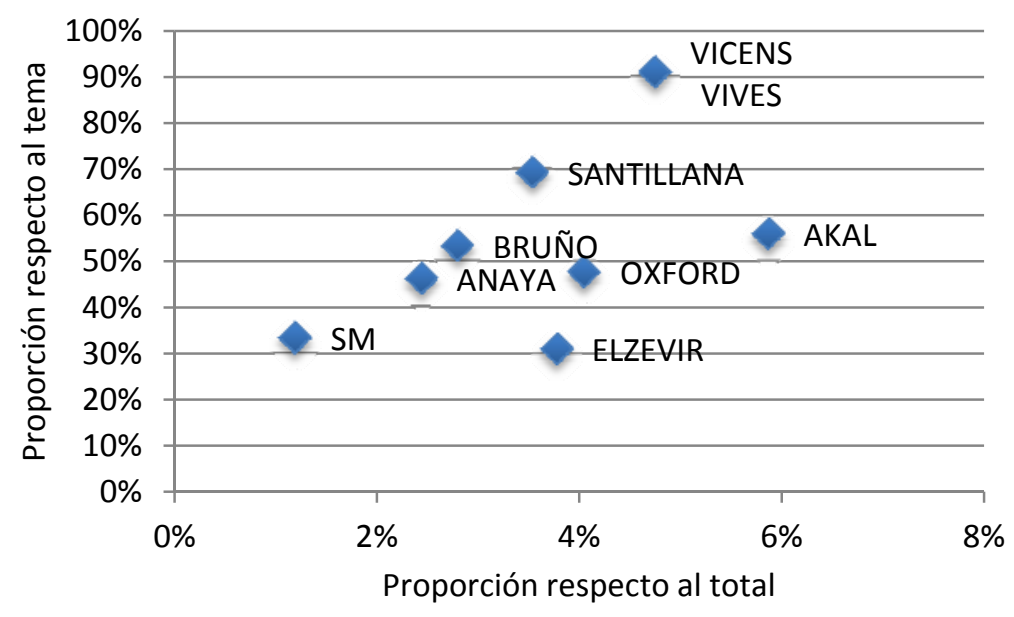

Fig.2. Proporción dedicada a las fuentes de energía y ahorro energético respecto al tema vs. proporción respecto al total.

Con respecto al ítem de las ideas previas erróneas y posibles errores han sido pocos los detectados en los manuales analizados. Así, solo se han encontrado los errores "1" y "13". En uno de los libros analizados, Akal, aparece el hidrógeno como 
una fuente de energía y no como un vector energético. En otros dos libros, Anaya y Oxford, aparecen los biocombustibles como un tipo de fuente de energía.

Se ha realizado un análisis, por un lado, de los tipos de fuentes de energía no renovables y por otro lado, de las fuentes de energías renovables que aparecen en los libros (Fig. 3). Como se puede comprobar, en cuanto a las fuentes de energía no renovables, es significativo que en ninguno de los libros aparece el gas procedente del fracking, mientras que el gas natural convencional aparece en un $88 \%$ de los libros, incluso "aportando más datos". Por otro lado, el carbón, el petróleo y la nuclear de fisión aparecen en todos los libros "aportando más datos". Por el contrario, la energía nuclear de fusión no aparece en el 75\% y aparece tanto con una "breve definición" (1 libro, el 13\% de las veces) como "aportando más datos" (también en un libro, es decir, el $13 \%)$.

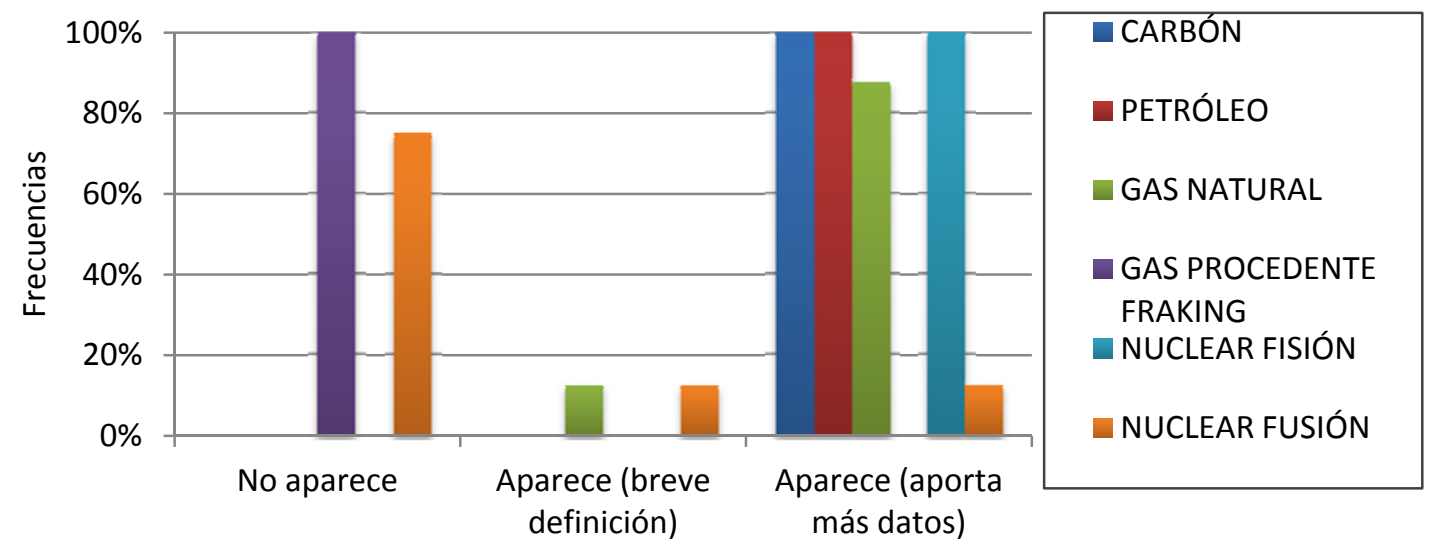

Fig.3. Frecuencias de los tipos de fuentes de energía no renovables.

En lo que respecta a los tipos de fuentes de energías renovables y vectores energéticos (Fig. 4), se podría decir que la eólica e hidráulica son las que aparecen en la mayoría de los libros "aportando más datos", concretamente en un $88 \%$. Hay que destacar que la biomasa, la geotérmica y la mareomotriz, no aparecen en un $13 \%$ (corresponde al libro de SM en los tres casos). La energía solar térmica y fotovoltaica y la biomasa aparecen "aportando más datos" en más del $60 \%$ de los libros. Solo un $25 \%$ hace referencia a otras fuentes de energía procedentes del mar que no sea la mareomotriz. El vector energético del hidrógeno no aparece en un $50 \%$ de los libros y aparece con una "breve definición" en el otro 50\%. Por tanto, podemos concluir que, en general, el análisis de la energía marítima se reduce a la mareomotriz, y no se trata (o muy superficialmente) otras tecnologías emergentes, y que están adquiriendo 
bastante importancia (undimotriz, de gradiente térmico, de salinidad, corrientes marinas o eólica marina). Algo parecido puede comentarse con respecto al Hidrógeno, cuya relevancia está aumentando en los últimos años. Quizás es por la novedad de estas tecnologías, o por no estar suficientemente probadas por lo que son consideradas con menor extensión.

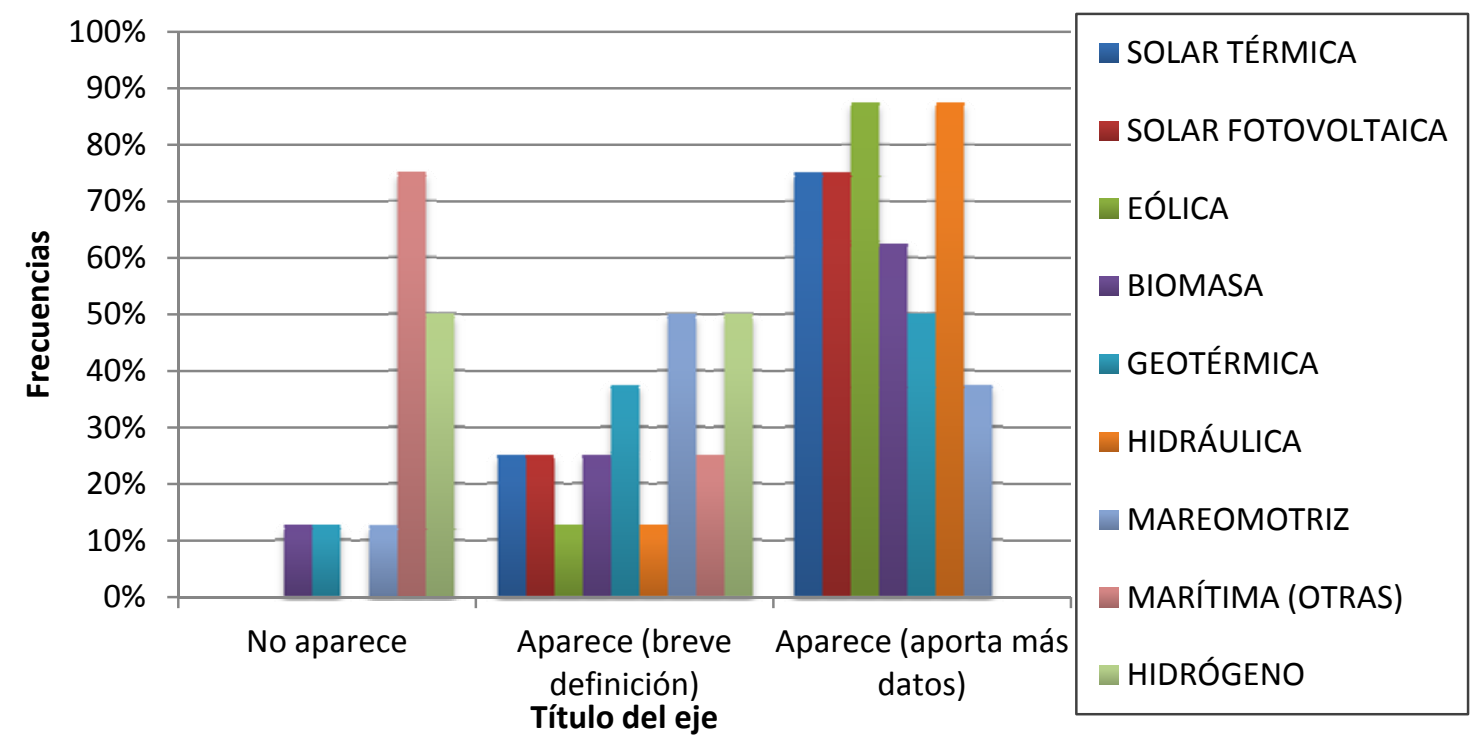

Fig.4. Frecuencias de los tipos de fuentes de energía renovables.

En el análisis de la crítica a los combustibles fósiles (Fig. 5), en el 100\% de los libros se mencionan que contaminan y que emiten $\mathrm{CO}_{2}$ a la atmósfera, el cual contribuye con el calentamiento global, y en un $88 \%$ también afirman que se van a agotar. Solo en un $13 \%$ (que corresponde al libro de SM) no se menciona esto, mencionando solamente que las reservas son limitadas.



Fig.5. Crítica a los combustibles fósiles.

En cuanto al ítem del límite del petróleo (Fig. 6) en un 63\%, no se establece, en un $25 \%$, se establece de forma absoluta y en un $13 \%$, se establece de manera 
condicionada, considerando las reservas actuales que puedan ser ampliadas, lo cual es lo más correcto ${ }^{7}$. Mientras que en el libro de Bruño se habla de 5 décadas, en el de Vicens Vives se calcula que nos quedan 100 años de reservas petróleo al ritmo actual de consumo aunque menciona que se espera encontrar nuevos yacimientos.



Fig.6. Límite del petróleo.

Para realizar el análisis estadístico de los contenidos de los libros se han calculado tres índices. El primero asigna un valor al tratamiento dado a los tipos de fuentes de energía y vector energético. El segundo índice, valora la crítica realizada a los combustibles fósiles, la alusión al ahorro energético, el límite del petróleo y la existencia de un apartado dedicado a concienciar al alumnado. El tercero y último es un índice global para todo el contenido.

El primer índice (Fig. 7) se ha calculado sumando, para cada fuente de energía y vector energético, los valores 0,1 ○ 2, y posteriormente dividiendo por la puntuación máxima posible (28, que obtendría un libro que recibiera un "2" en los 14 ítems considerados). De esta forma se obtiene un valor normalizado, comprendido entre 0 y 1. Oxford es el más valorado (con una puntuación de 0,82), seguido de Santillana y Akal $(0,79$ ambos), mientras que el que menor puntuación ha obtenido es SM (con un $0,57)$.

\footnotetext{
${ }^{7}$ Es importante ser riguroso en este tema. Hoy en día, aún se desconoce cuál es el límite de los recursos no renovables. Lanzar un mensaje alarmista sin fundamentarlo en datos reales puede tener un efecto contraproducente. Imaginemos que un libro predice que un cierto recurso se agotará en 50 años. Si en ese tiempo se encuentran nuevos yacimientos, el límite será superior. Esto puede inducir a un escepticismo sistemático, también infundado “¿Cómo me voy a creer que realmente es urgente encontrar nuevas fuentes de energía, u otros mensajes alarmistas, como los relacionados con el efecto invernadero, cuando veo que las predicciones pesimistas sistemáticamente se incumplen?". De ahí que se haya dado importancia a este aspecto, y que haya contribuido a la valoración global de los textos analizados.
} 


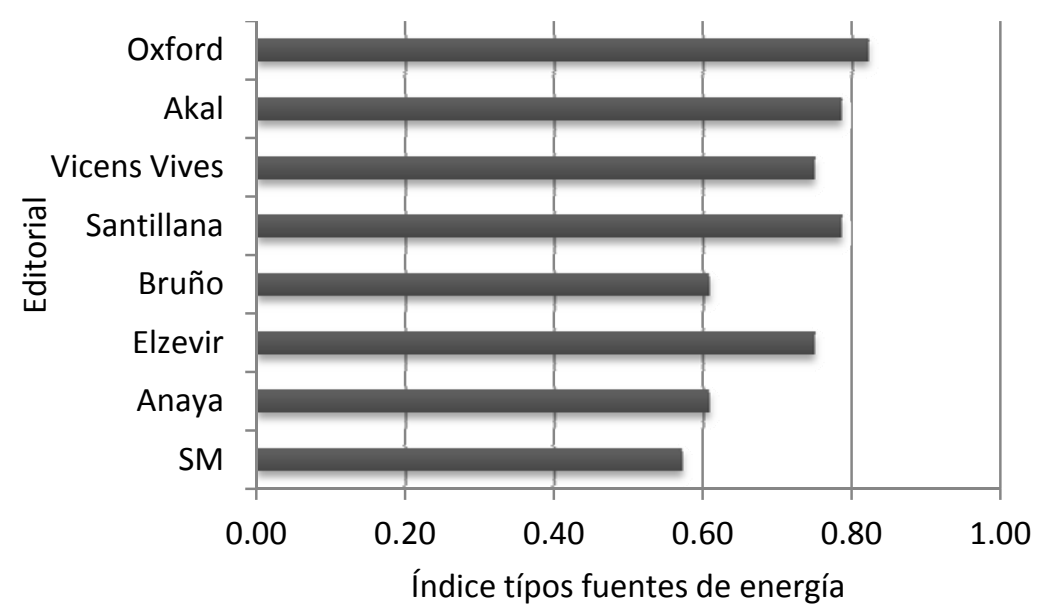

Fig.7. Índice sobre los contenidos de los tipos de fuentes de energía y vector energético.

En el segundo índice se ha calculado de la misma forma que el anterior. En este caso el máximo valor es 7, puesto que se le daba "1" a cada uno de los 5 ítems (alusión al ahorro energético, crítica a los combustibles fósiles con los tres subítems, apartado dedicado a concienciar) y el valor de " 2 " en el límite del petróleo si se establecía de manera condicionada, considerando las reservas actuales que puedan ser ampliadas. De esta forma se ha sumado la puntuación de todos los ítems de cada editorial y se ha dividido entre 7 obteniendo un valor también entre 0 y 1 . En este caso (Fig. 8), la editorial de Vicens Vives es la que ha alcanzado la mayor puntuación, con el máximo posible, seguido de Bruño y Anaya (0,86 en ambos casos). SM es la que tiene menor puntuación $(0,57)$.

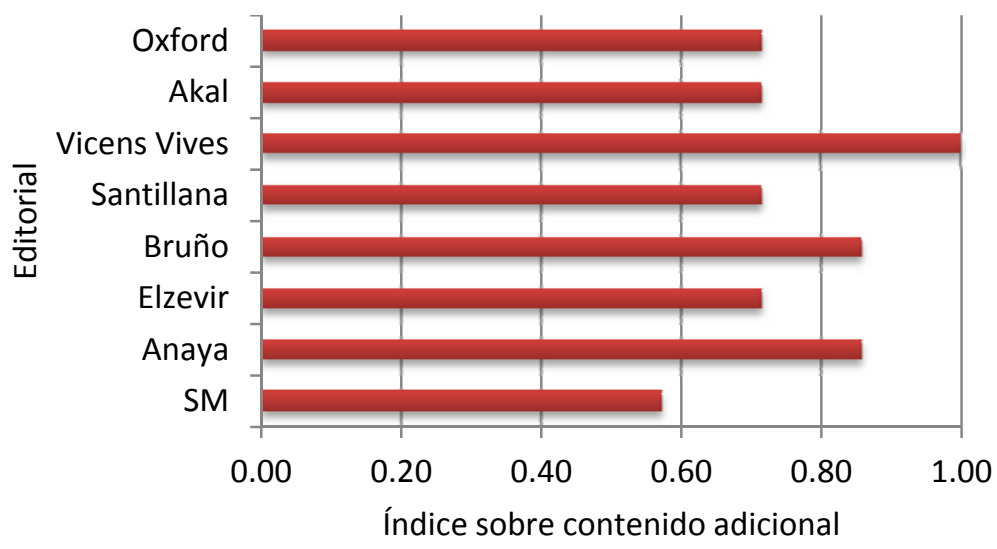

Fig.8. Índice sobre contenido adicional.

Por último, el índice global de los contenidos se ha obtenido calculando el promedio de los dos anteriores. El resultado final de los contenidos (Fig. 9) ha determinado que la editorial de Vicens Vives resalta sobre las demás con una 
puntuación de 0,88 sobre 1 , seguido de Oxford con 0,77 . SM es la que obtiene menor puntuación $(0,57)$, quedando a bastante distancia de las demás.



Fig.9. Índice global de los contenidos.

\subsection{Resultados del análisis de las imágenes}

En el análisis de las imágenes se ha podido comprobar que, en general, la mayoría corresponden a las fuentes de energía renovables, destacando la editorial Elzevir (el 91\% de las imágenes, Fig. 10). Vicens Vives y Bruño tienen prácticamente la misma proporción de imágenes de fuentes de energías renovables que no renovables.

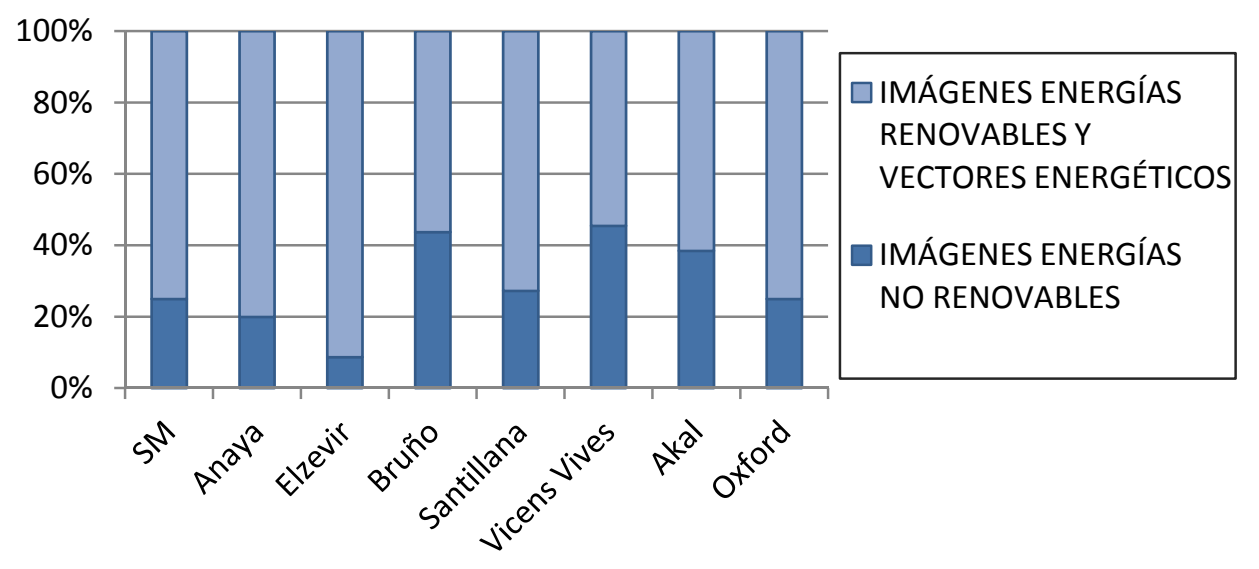

Fig.10. Proporción de imágenes de fuentes de energía no renovables y fuentes de energía renovables y vectores energéticos.

En cuanto a los tipos de fuentes de energías no renovables mostradas (Fig. 11), la de fisión es la más representativa, seguida del petróleo y el carbón. No se muestra ninguna imagen del gas procedente del fracking puesto que como se ha mencionado anteriormente, no aparece en los libros. En Bruño y Akal se muestran imágenes correspondientes a la energía de fusión ( 2 y 1 , respectivamente). 


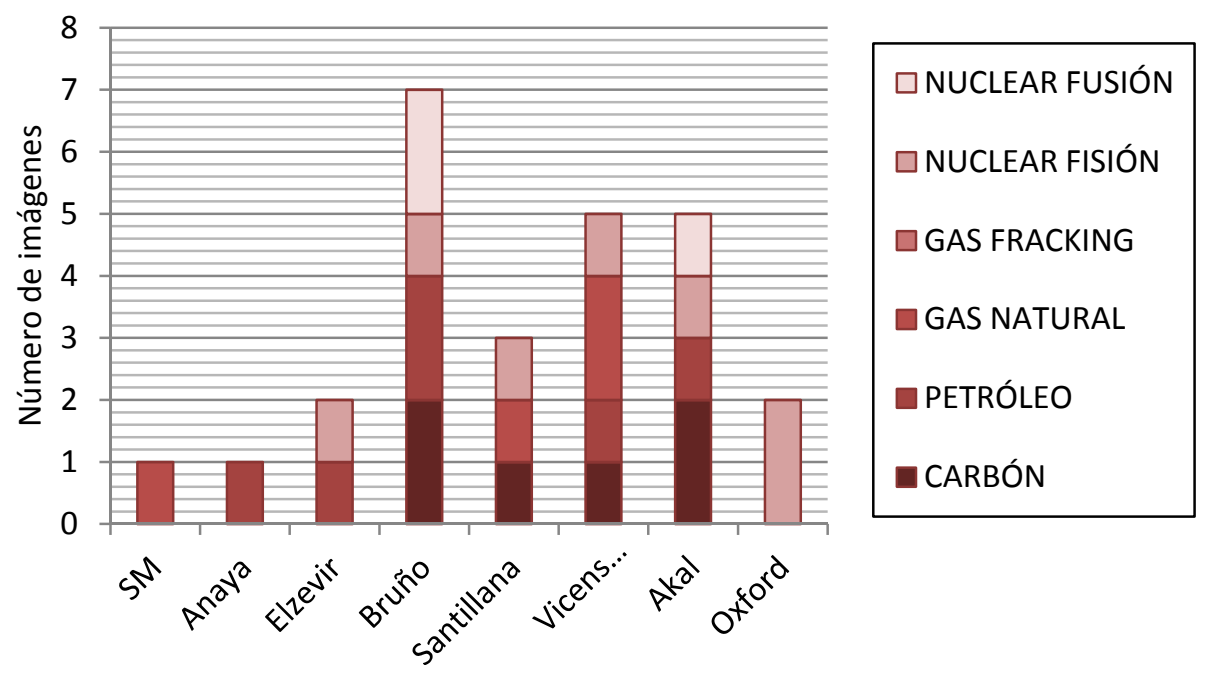

Fig.11. Número de imágenes de las fuentes de energía no renovables.

La energía solar térmica y la biomasa son las que más se representan en los distintos manuales, seguido de la fotovoltaica y eólica (Fig. 12). Elzevir muestra el mayor número de imágenes de fuentes de energía renovables y vector energético, concretamente 21 , mientras que SM es el de menos, con solamente 3 . No se representan imágenes sobre otras fuentes de energía del mar, distintas a la mareomotriz.

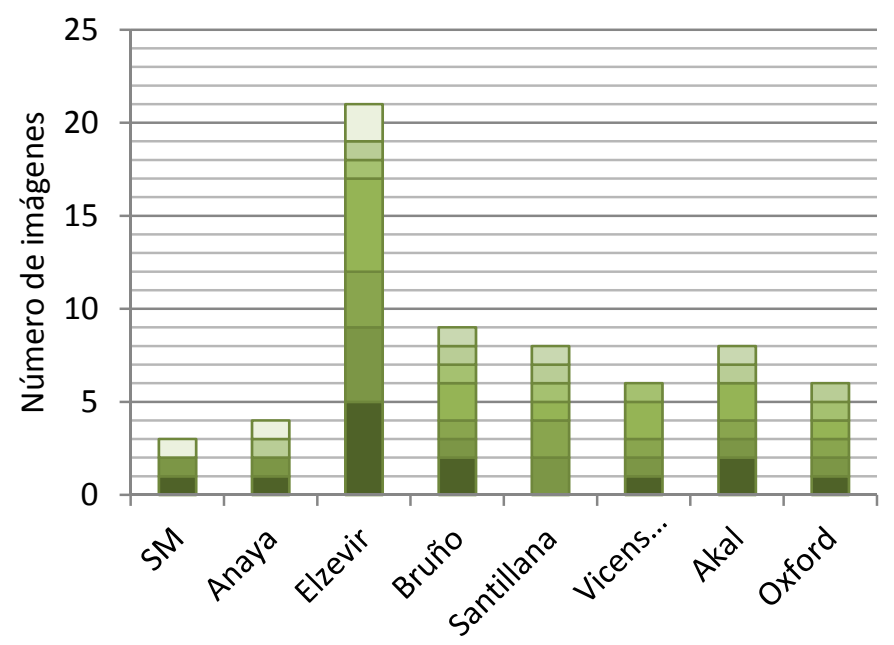

\begin{tabular}{|l|}
\hline HIDRÓGENO \\
$\square$ MAREOMOTRIZ \\
$\square$ HIDRÁULICA \\
$\square$ GEOTÉRMICA \\
$\square$ BIOMASA \\
$\square$ ÉOLICA \\
$\square$ SOLAR FOTOVOLTAICA \\
$\square$ SOLAR TÉRMICA
\end{tabular}

Fig.12. Número de imágenes de las fuentes de energía renovables y vector energético.

Para calcular los índices estadísticos sobre las imágenes se han definido dos intermedios para valorar las imágenes correspondientes a cada tipo (renovable y no renovable) por separado, además de otro global que evalúa ambos.

Para obtener cada uno de los índices que hemos denominado intermedios, primero se ha valorado el número de imágenes. De esta forma, si tenemos bastantes 
imágenes, tendremos una puntuación más elevada que si tenemos menos. Si aparecen entre 0 y 20 imágenes, se le ha dado una puntuación entre 0 y 1, calculada linealmente $(\mathrm{n} / 20)$. Si tiene más, se le ha dado un valor constante 1 , puesto que más imágenes ya no aportarían nada nuevo.

Por otra parte, lo ideal es que de entre ellas, la mayoría sean explicativas. Para ello, se ha creado otro índice, que es simplemente la proporción de "2", es decir, la proporción de imágenes que son explicativos en cada libro de texto. De esta forma, si todas las imágenes son ilustrativas saldría 0 , y si todas las imágenes son descriptivas, saldría 1. Después se han ponderado los valores anteriores, con un peso de 0,7 asignado al número de imágenes y de 0,3 para la "calidad" (es decir, que sean descriptivas y no ilustrativas). De esta forma se obtiene un valor justo en función del número de imágenes.

Como resultado (Fig. 13) se ha obtenido que Bruño es el más destacable en cuanto al número y calidad de sus imágenes correspondientes a las fuentes de energías no renovables (con un valor de 0,50), seguido de SM y Akal. El que menor puntuación ha obtenido has sido Anaya, con un 0,04.

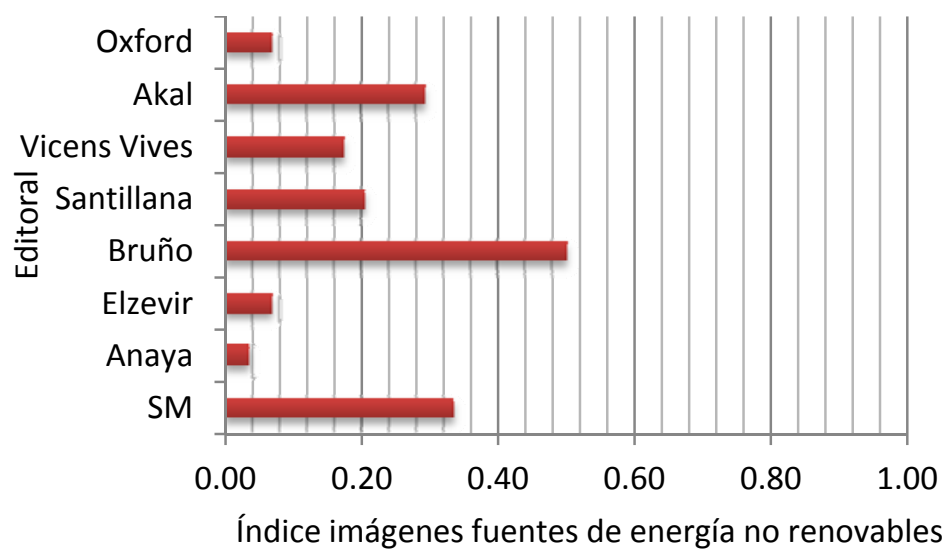

Fig.13. Índice de las imágenes de fuentes de energía no renovables.

En lo que respecta a las imágenes de fuentes de energía renovables (Fig. 14), destaca Elzevir con un valor de 0,71, seguido de Bruño y después Santillana. Al contrario que en el caso anterior, $\mathrm{SM}$ es una de las que menos puntuación ha obtenido, al igual que Oxford y Vicens Vives, con un 0,21. 




Fig.14. Índice de las imágenes de fuentes de energía renovables.

El índice global de las imágenes se ha ponderado dándole mayor importancia a las fuentes de energía renovables (con un 0,6 frente a un 0,4 para las imágenes de fuentes de energía no renovables). Como se puede observar en la Figura 15, el resultado final determina que Bruño es la editorial de mayor puntuación con un 0,49, seguido de Elzevir con un 0,46 y Akal con un 0,33. En último lugar se encuentra Anaya con un valor de 0,19.

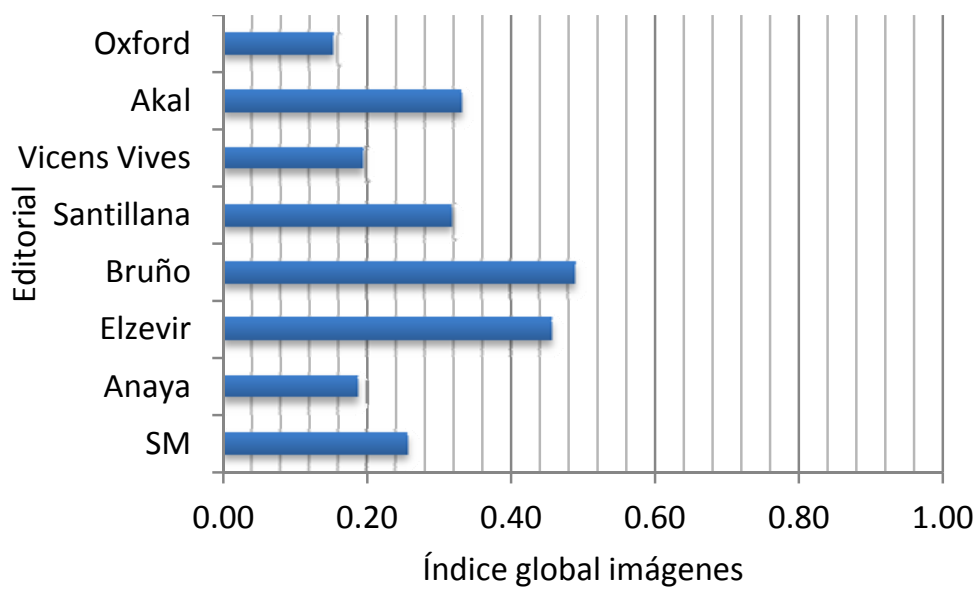

Fig.15. Índice Global de las imágenes.

\subsection{Resultados del análisis de las actividades}

En primer lugar se ha calculado la proporción de actividades sobre fuentes de energía y ahorro energético con respecto al número total del tema. El porcentaje obtenido determina, como se puede observar en la Figura 16, una gran diferencia entre el libro de Vicens Vives, con un 100\%, y el resto de las editoriales. Después sigue Santillana con un 71\%. La editorial con menor proporción es Oxford. 


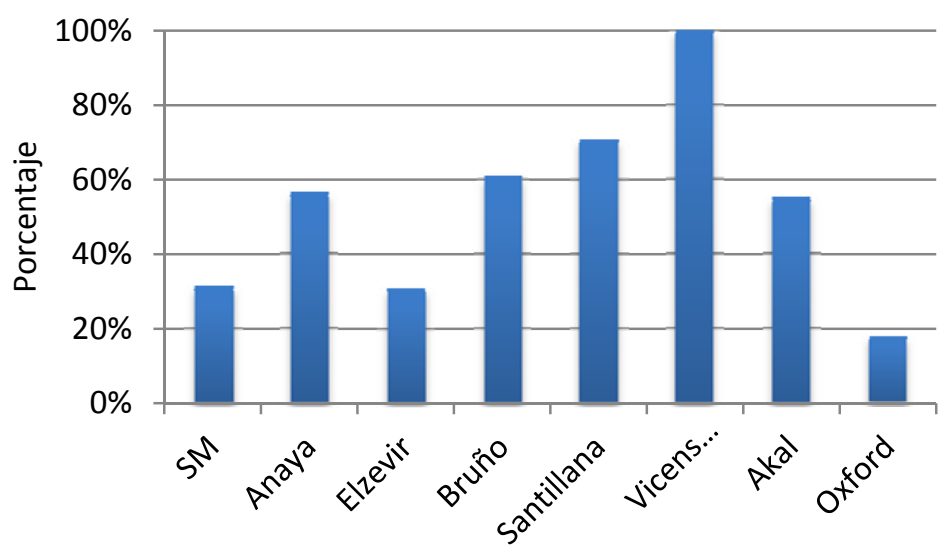

Fig.16. Proporción de actividades sobre fuentes de energía y ahorro energético respecto al número total de actividades del tema.

En cuanto al estudio del tipo de actividades, la primera clasificación ha consistido en diferenciar entre experimentales y de lápiz/papel. Se puede observar en la Figura 17 que en la mayoría de los libros no existen actividades experimentales, y solo en Elzevir, Bruño y Santillana nos encontramos con una pequeña proporción, del 5\%, 4\% y $2 \%$, respectivamente.

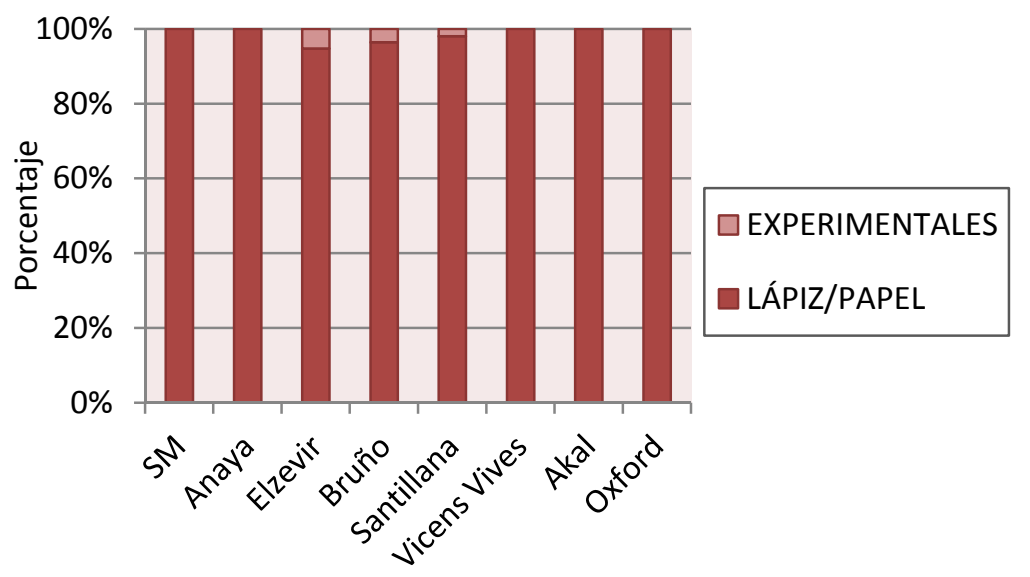

Fig.17. Porcentaje de actividades experimentales y de lápiz/papel

En cuanto al tipo de solución, cerrada o abierta, se puede concluir que en la mayoría de los libros, excepto en Elzevir, predominan las actividades del primer tipo (Fig. 18). Además, éste contiene más actividades de solución abierta (un 53\%) que de solución cerrada (un 47\%). Hay que destacar que el $100 \%$ de las actividades del libro de Bruño son cerradas. 




Fig.18. Porcentaje de actividades de solución abierta y solución cerrada

En cuanto a los procedimientos (Fig. 19), en todos los manuales predominan, con gran diferencia, los ejercicios (es decir, las respuestas se encuentran en el mismo libro). Coincidiendo con que Bruño tenía todas la actividades de solución cerrada, además, presenta la mayor proporción de ejercicios (el 86\%), contando solamente con un $7 \%$ de actividades de indagación y otro $7 \%$ de actividades creativas. SM es la que tiene mayor número de estas últimas (un 19\%), y solamente un $44 \%$ de ejercicios.

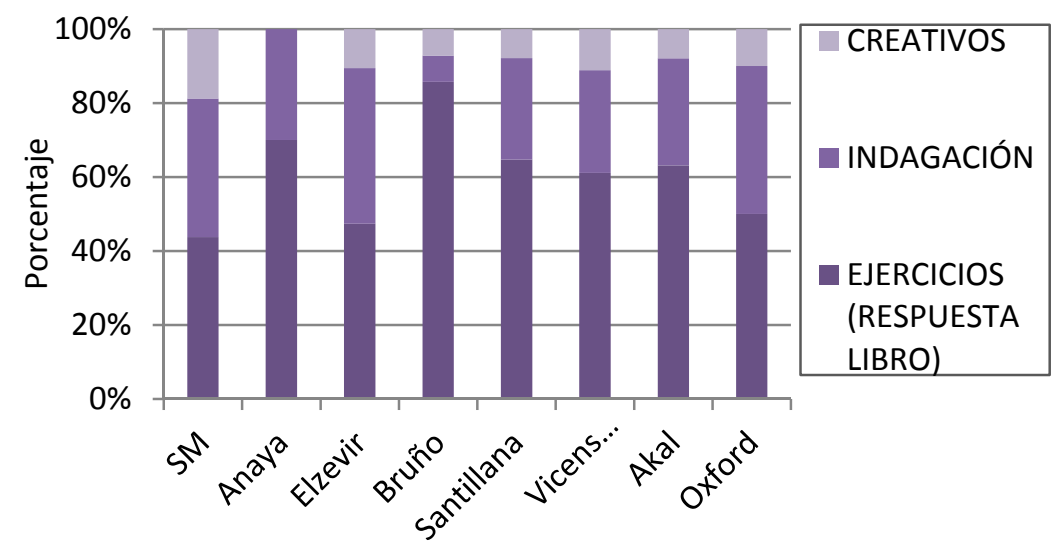

Fig.19. Porcentaje de actividades creativas, indagación y de ejercicios (respuesta libro).

Para calcular el índice valorativo de este apartado se ha tenido en cuenta, por un lado, la proporción de actividades experimentales (índice 1), y por otro, la proporción de actividades de solución abierta (índice 2). Después, se ha definido otro (índice 3) para las de indagación y creativas, según la siguiente fórmula: K3=(proporción indagación/2) + proporción creativos. De esta forma se valoran más las creativas. A los ejercicios se les ha asignado un valor 0 , de manera que un libro de texto que solamente contemple tareas de este tipo, tiene una puntuación mínima. 
Para obtener el índice global de este apartado, se ha valorado el número de actividades, asignándole una puntuación entre 0 y 1 si tiene entre 0 y 50 , y calculada linealmente $(\mathrm{n} / 50)$. Si tiene más, se le ha dado un valor constante 1 . Después se ha obtenido el promedio de las 4 puntuaciones.

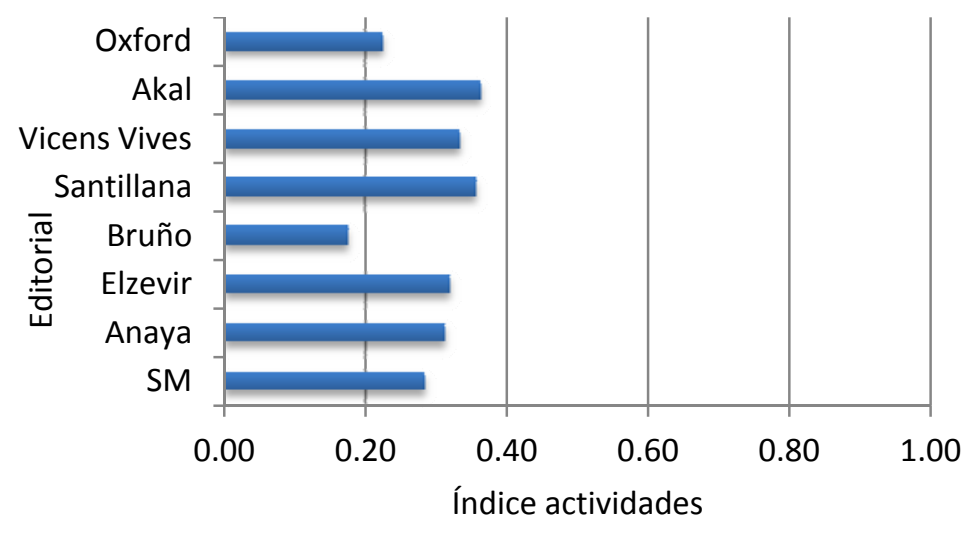

Fig.20. Índice de las actividades

Como podemos observar en la Figura 20, las actividades de Akal y Santillana son las más valoradas (con 0,36 ambas), seguidas de las de Vicens Vives y Elzevir (con un 0,33 y 0,32 , respectivamente). La editorial que ha conseguido menor puntuación es Bruño, con 0,18.

\subsection{Resultados del análisis global}

Finalmente se ha obtenido un índice global que incluya todos los aspectos anteriormente analizados. Para este se han tenido en cuenta los índices finales de los contenidos, las imágenes y las actividades. Para ello se han ponderado con un 0,4 los contenidos, con un 0,1 , las imágenes y el mayor valor se le ha asignado a las actividades, con un peso de 0,6.

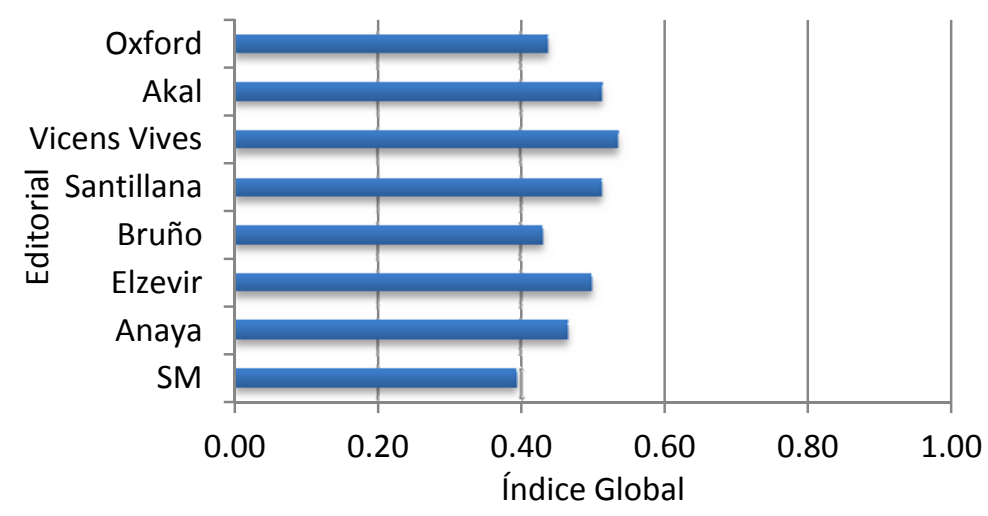

Fig.21. Índice Global del análisis de libros 
Como se puede apreciar en la Figura 21, los resultados finales obtenidos le asignan al libro de la editorial Vicens Vives la mayor puntuación $(0,54)$, seguido de Santillana y Akal (con 0,51 ambas). El que menor puntuación tiene es SM $(0,39)$. 


\section{BANCO DE ACTIVIDADES}

El desarrollo de las actividades se ha llevado a cabo siguiendo en todas ellas la misma estructura. En primer lugar se comienza con un título que intenta reflejar lo que se va a realizar. El primer apartado llamado fundamentación, trata de aportar ya sea información científica sobre el tema que se va a trabajar o sobre el tipo de actividad en cuestión, con ello se pretende aportar datos para poner en situación al docente que quiera impartirla.

En el punto siguiente se introducen los elementos curriculares, divididos en dos aspectos diferentes, aunque relacionados. Por un lado, se presenta una tabla resumen de cada actividad. En ella se incluyen, en primer lugar, los objetivos específicos, relacionados, en la medida de lo posible, con los objetivos generales de área establecidos en el Real Decreto 1631/2006. Una segunda columna incluye los contenidos a cubrir. En la tercera quedan reflejados los criterios de evaluación con los que se van a evaluar los objetivos específicos. Por otro lado, se incluyen las competencias básicas establecidas en el Real Decreto 1631/2006 a las que se contribuyen con el desarrollo de la actividad.

A continuación tenemos un apartado con los materiales y recursos que se van a utilizar y de los que debemos disponer para el desarrollo de la actividad. En la descripción se especifica, paso por paso, como ésta debe ir transcurriendo ésta. Se divide en diferentes partes, que van a variar dependiendo de cada una. En este apartado se incluye un punto con la duración aproximada, intentando reflejar el número de sesiones que llevaría su realización y una secuencia temporal.

Por último, se incluye, en algunas actividades, un apartado con alternativas al punto anterior. De esta forma existen varias posibilidades para su desarrollo dependiendo de los objetivos que se quieran perseguir.

Todas las actividades que se presentan a continuación están desarrolladas para el segundo curso de Educación Secundaria Obligatoria de acuerdo con los contenidos establecidos en el Real Decreto 1631/2006, pero ello no quiere decir, que no puedan ser modificadas y adaptadas para cualquier otro curso. 


\subsection{CONSTRUIMOS UNA CHIMENEA SOLAR}

\subsubsection{FUNDAMENTACIÓN}

Seguro que todos en casa disponemos de algún aparato para enfriar o calentar nuestra vivienda que requiere electricidad. Pues bien, en esta actividad vamos a conocer un sistema con la misma finalidad, pero que utiliza la energía solar. Además vamos a construir nuestra propia chimenea solar.

La chimenea solar es un sistema que utiliza la radiación procedente del sol para calentar el aire de su interior, disminuyendo su densidad y creando por tanto un flujo ascendente por convección natural. Se suelen pintar de negro para aumentar la cantidad de radiación absorbida. Generalmente se utilizan para mejorar la ventilación natural y para refrigeración o calefacción de un edificio.

Otro sistema que también utiliza una corriente de aire inducida por convección natural es la torre solar. Su funcionamiento varía ligeramente. Además de la chimenea, tiene una cubierta de un material que bloquea la radiación infrarroja, provocando un efecto invernadero en su interior (Fig. 22). Cuando incide radiación solar, aumenta la temperatura del aire situado debajo de esta cubierta, disminuyendo su densidad y generándose un flujo ascendente que sale por la torre y mueve unas turbinas colocadas en su base. La velocidad del aire a la salida puede superar los $50 \mathrm{~km} / \mathrm{h}$ (Fig. 23). Así pues, de esta forma, se genera electricidad. Además, para aumentar tanto su eficiencia como el tiempo de operación, suelen colocarse bajo la cubierta almacenadores térmicos, sustancias que almacenan gran cantidad de energía térmica (es decir, con un alto calor específico), como puede ser el agua. Durante el día absorben energía y aumenta su temperatura. Durante la noche emiten la energía acumulada, calentando el aire de la base, por lo que el proceso puede continuar varias horas más aunque no esté incidiendo radiación solar. 


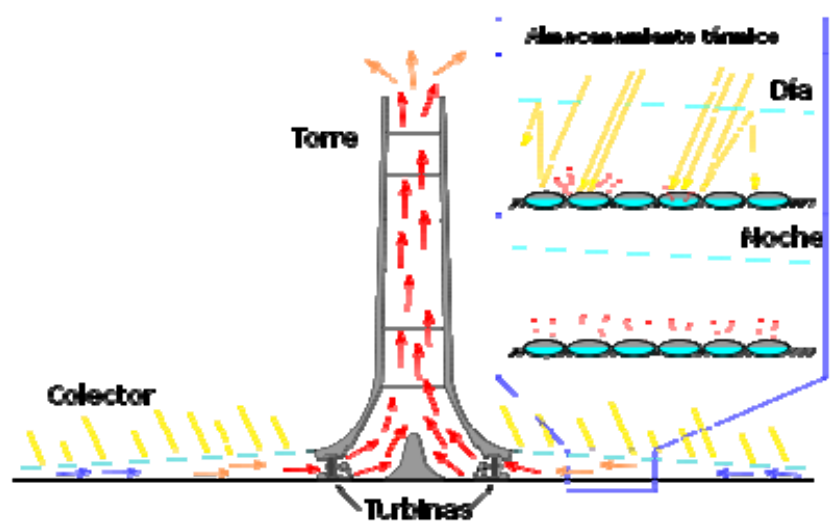

Fig.22. Esquema de funcionamiento de una torre solar [2].

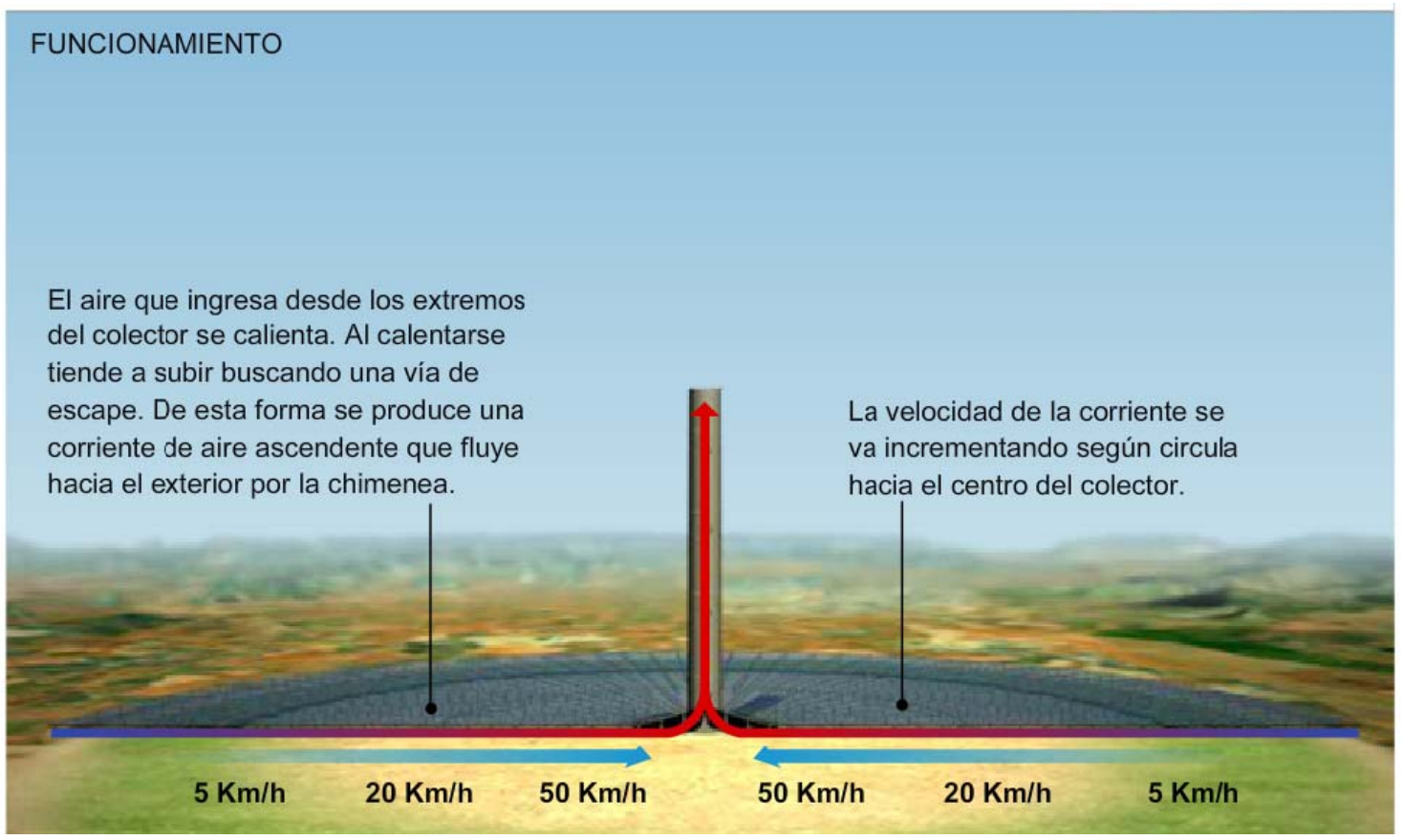

Fig. 23. Esquema del flujo de aire en el interior de una torre solar [3].

Como curiosidad, puede señalarse el importante papel que ha jugado nuestro país en el desarrollo de este tipo de instalaciones. Fue el coronel español Isidoro Cabanyes quien diseño la primera torre solar, en el artículo de la revista La Energía Eléctrica con el título de "Proyecto de motor solar". España ha sido pionera en el estudio de este tipo de instalaciones, un ejemplo de ello es la torre solar experimental construida en Manzanares que ha tenido importancia a nivel mundial.

\subsubsection{ELEMENTOS CURRICULARES}

\section{OBJETIVOS, CONTENIDOS Y CRITERIOS DE EVALUACIÓN}

Los objetivos, contenidos y criterios de evaluación que se trabajan en esta actividad quedan recogidos en la tabla que se muestra a continuación: 


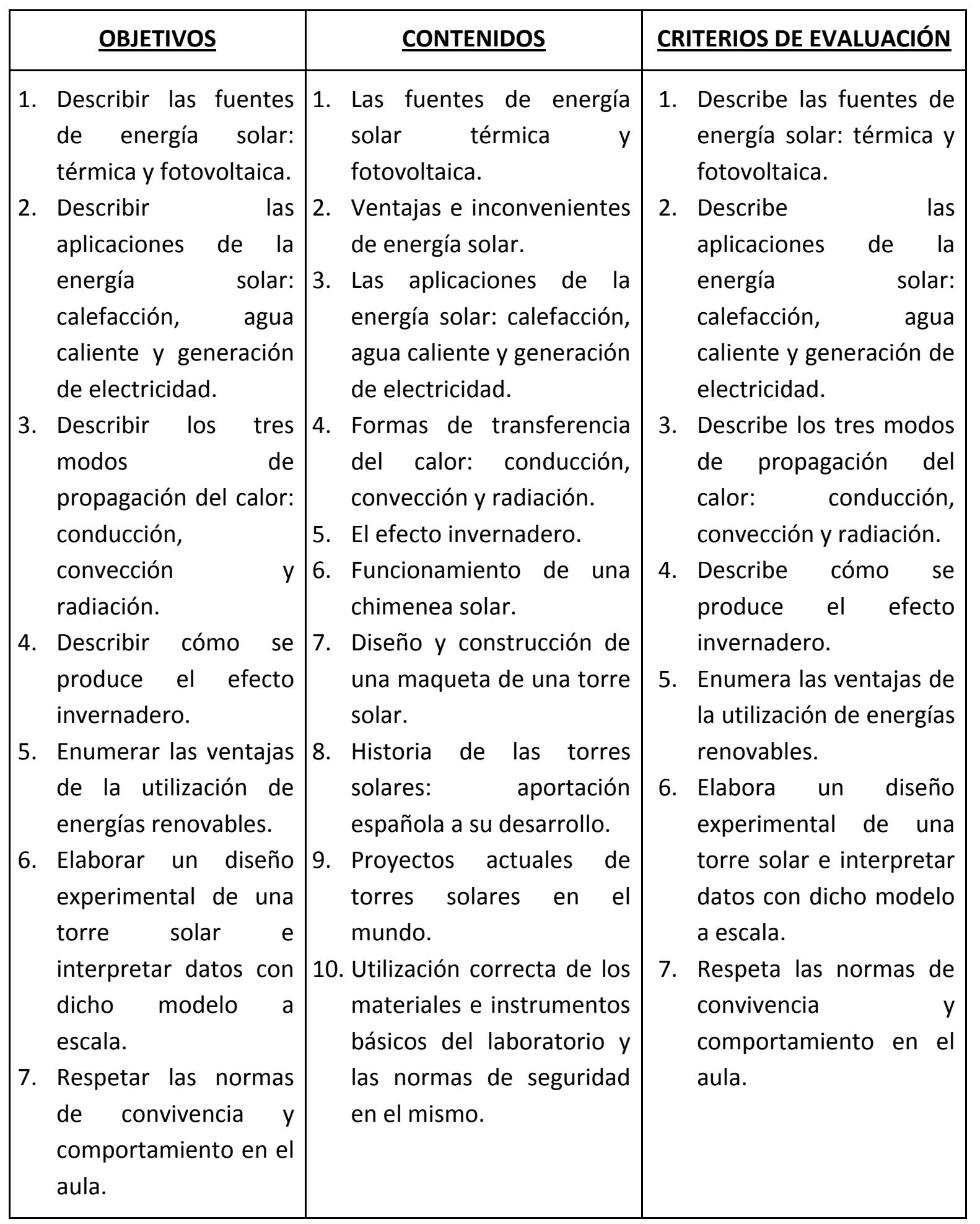

\section{COMPETENCIAS BÁSICAS}

Con esta actividad se contribuye al desarrollo de las siguientes competencias básicas establecidas en el Real Decreto 1631/2006: 
CB1. Competencia en comunicación lingüística. Esta competencia se desarrolla porque deben explicar los distintos procesos que tienen lugar en la torre solar utilizando un lenguaje adecuado durante sus intervenciones de clase.

CB2. Competencia matemática. Los alumnos y alumnas deben interpretar los datos obtenidos en la medición de la temperatura y representarlos en una gráfica.

CB3. Competencia en el conocimiento y la interacción con el mundo físico. Deben realizar observaciones directas del funcionamiento de una chimenea o torre solar.

CB4. Tratamiento de la información y competencia digital. Deben buscar, obtener, procesar y comunicar información sobre la historia de la chimenea o torre solar, los proyectos que se están desarrollando actualmente, e indagar sobre el proyecto "Enviromission".

CB5. Competencia social y ciudadana. El alumnado debe tomar decisiones cuando estén trabajando en grupo y elegir cómo comportarse tanto en las intervenciones en clase como durante el trabajo en grupo.

CB8. Autonomía e iniciativa personal. Deben cooperar y trabajar en equipo elaborando la chimenea o torre solar. Así como dialogar y negociar la organización en la realización del modelo experimental.

\subsubsection{MATERIALES Y RECURSOS}

$>$ Aula de tecnología, ordenador y proyector.

> Tres o cuatro botellas de plástico transparente de 1,5litros.

> Un plato macetero de plástico negro o una tapa de hojalata pintada de negro mate.

$>$ Un palito de madera de maqueta o similar.

> Una plancha de metacrilato transparente o de acrílico de $30 \times 30 \mathrm{~cm}$ de lado y $2 \mathrm{~mm}$ de grosor.

$>$ Una chincheta y un alfiler.

$>$ Tornillos de longitudes diferentes y tuercas.

$>$ Unas tijeras, cúter o una sierra.

> Reglas, compás y lápiz.

> Pistola de silicona transparente.

$>$ Destornillador y llave inglesa. 
Termómetro.

\subsubsection{DESCRIPCIÓN DE LA ACTIVIDAD}

\section{1a Parte}

El profesor o profesora presentará en el aula una maqueta de una chimenea solar y la expondrán a la luz solar para que los alumnos y alumnas vean su funcionamiento. Comprobarán cómo se mueve el molinete y aumenta su velocidad a medida que va recibiendo radiación (Fig. 24). El alumnado tendrá que, en primer lugar describir lo que está ocurriendo; en un segundo momento tendrán que explicar, utilizando los principios de la Ciencias, cómo es su funcionamiento. El profesor o profesora presentará las siguientes cuestiones para iniciar un debate en clase:

- ¿Cómo creéis que funciona?

- ¿ ¿Por qué se mueve el molinillo?

- ¿Qué factores intervienen?

- ¿Para qué pensáis que se puede utilizar?

- ¿Qué fuente de energía utiliza?

- ¿Qué diferencias hay entre la energía solar térmica y la energía solar fotovoltaica?

Se les pedirá a los alumnos y alumnas que dibujen y enumeren las partes de una torre solar e indiquen, con una flecha, el sentido del movimiento del aire.

Después se presentará una animación flash [4] donde se muestra un proyecto de construcción de una torre solar en Fuente el Fresno. En ésta se explica la ubicación, dimensiones, funcionamiento y sus aplicaciones. A partir de esta animación, los alumnos y alumnas tendrán que explicar en qué consiste y cómo tiene lugar la convección y el efecto invernadero.

\section{2a Parte}

Una vez observada la maqueta del profesor o profesora, el alumnado va a elaborar su propia chimenea o torre solar. Tendrán como referencia la misma pero a la vez se les pedirá que busquen en casa, utilizando las tecnologías de la información y 
comunicación, los pasos que han de seguir para su construcción. Se dividirán en grupos de 3 o 4 personas dependiendo del número de alumnos y alumnas del grupo-clase. Para construir la chimenea o torre solar deberán seguir los siguientes pasos (modificado de Bolaño, (1997)):

1) Cortar la base de dos botellas y la parte superior, donde tienen el tapón, de modo que se consiga una forma cilíndrica.

2) Para realizar el molinete, medir el diámetro interior de la futura chimenea, restarle 1,5 cm y dividirlo por dos. El resultado obtenido se traslada, mediante un compás y se dibuja un círculo sobre un papel. Es importante marcar bien el centro. Con la misma distancia del compás marcar seis puntos equidistantes en el círculo dibujado. A continuación, se dibujan las seis líneas que unen estos puntos al centro del círculo (radios). Después, se cierra el compás hasta $1,5 \mathrm{~cm}$ y se traza un círculo concéntrico usando como punto central el mismo del círculo anterior. Hacer seis cortes desde el borde del círculo exterior hasta la línea del interior, torciendo un poco y por igual las aspas para darles un poco de inclinación.

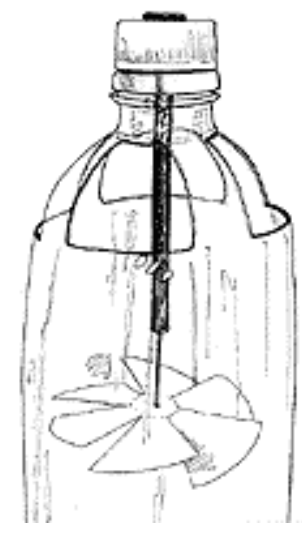

Fig. 24. Esquema de la maqueta de una torre solar [5].

3) Pasar un alfiler por el centro del molinete.

4) Cortar la base de una tercera botella y en la tapa clavar con una chincheta un palo de unos $10 \mathrm{~cm}$ hacia el interior de la botella, más o menos por su centro. En el otro extremo del palo, clavar el molinete con el alfiler.

5) Recortar, tres o cuatro ventanas en el cono de la botella. Tener en cuenta que entre el molinete y las ventanas debe existir un tramo de chimenea por lo que las ventanas no pueden ser demasiado largas. 
6) Unir un cilindro con la botella y encima de ésta el otro cilindro con silicona transparente.

7) Realizar un pequeño agujero en el cilindro para poder introducir un termómetro.

8) Recortar un círculo de $30 \mathrm{~cm}$ de diámetro en el metacrilato y en su centro un agujero concéntrico con la misma medida que el molinete.

9) Hacer un corte en el círculo de metacrilato para poder solapar los dos bordes, formando así un embudo. Con la ayuda de una abrazadera para que no se deshaga el embudo, agujerear el metacrilato y atornillar las dos solapas.

10) Para unir el cono de metacrilato con el plato macetero negro, atornillar en el cono unos tacos de plástico o madera de unos $2 \mathrm{~cm}$ de alto a $1 \mathrm{~cm}$ del borde del cono. A continuación atornillar estos tacos al plato macetero.

11) Unir la chimenea al cono con silicona transparente, asegurarse de que la chimenea queda lo más recta posible.

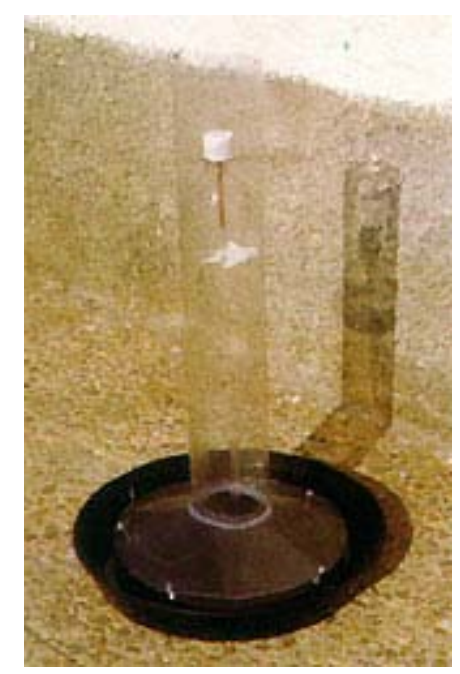

Fig.25. Maqueta de una chimenea solar [6].

\section{3a Parte}

Terminada la construcción de la chimenea solar, los alumnos y alumnas saldrán al patio para probarla con la radiación solar. Deberán medir la temperatura del interior, tomar los datos y generar una gráfica con la temperatura en función del tiempo. Una vez hayan comprobado los resultados, cada grupo se reunirá durante 15 min y elegirán a un portavoz que tendrá que exponer la experiencia del grupo con el experimento, si han podido observar el funcionamiento correcto de la chimenea solar y dar sus opiniones acerca del uso de la energía solar como fuente de energía 
alternativa a las convencionales, así como las ventajas e inconvenientes que consideran que tiene. Se volverán a comentar las preguntas enumeradas en la primera parte para comparar las respuestas después de realizar el experimento.

\section{$\underline{\text { 4a Parte }}$}

Se les pedirá que busquen como tarea, utilizando las tecnologías de la información y comunicación, la historia sobre la chimenea o torre solar, quién la inventó, algunos proyectos que se conozcan, ventajas e inconvenientes de la utilización de la energía solar y comenten en qué consiste el proyecto "Enviromission" [7].

\section{DURACIÓN DE LA ACTIVIDAD}

Esta actividad se hará en un total de tres sesiones. Unos 165 minutos aproximadamente.

En la primera sesión se utilizarán 35 min para la puesta en funcionamiento de la maqueta del profesor o profesora de la chimenea o torre solar y la intervención del alumnado. En el resto de la sesión se comenzará la elaboración de la chimenea o torre solar. La segunda sesión se dedicará completa para la construcción de la chimenea solar. Y por último en la tercera sesión saldrán al patio para comprobar los resultados con una duración de 40 minutos. Después se dejará 20 min para elegir el portavoz y poner en común sus experiencias. En el resto de la sesión expondrán cada uno de los representantes de los grupos. La 4ạ parte se realizará en casa y se presentará como trabajo.

\subsubsection{ALTERNATIVAS}

\section{ALTERNATIVA 1}

Se modifica la primera parte de la siguiente manera: se comenzará con una lluvia de ideas sobre cuáles son las fuentes de energía, qué energías renovables conocen y qué aplicaciones tienen. Después el profesor o profesora continuará con la explicación de la energía solar y sus aplicaciones. Se pondrá como ejemplo la chimenea o torre solar. Para ello se acompañará de una animación flash [4] donde se muestra un proyecto de construcción de una torre solar en Fuente el Fresno. En ésta se explica la 
ubicación, dimensiones, funcionamiento y sus aplicaciones. Además se les contará la historia de la chimenea o torre solar. Con el funcionamiento de la torre solar se les explicará qué es la convección y como sucede. La 2ª , 3a y 4aㅡ parte se quedan igual. 


\section{2. ¡CONSTRUYE TU HORNO SOLAR!}

\subsubsection{FUNDAMENTACIÓN}

Un horno solar es una estructura que utiliza radiación solar para alcanzar altas temperaturas. En los reflectores parabólicos o helióstatos se concentran la luz sobre un punto focal, pudiéndose alcanzar en ese punto una temperatura de hasta $3500^{\circ} \mathrm{C}$. Este tipo de horno solar es usado industrialmente para generar electricidad, fabricar combustible de hidrógeno o fundir acero.

El funcionamiento de un horno solar se basa en algunos principios físicos como el efecto invernadero, conducción, radiación, convección, reflexión, almacenamiento de calor, volumen de la caja y uso apropiado de colores y de pinturas especiales.

Cuando este tipo de aparato tiene pequeñas dimensiones, se usa para cocinar alimentos usando el Sol como fuente de energía, y se le denomina también cocina solar.

Las cocinas solares pueden ser de dos tipos: el tipo horno o caja que consiste en una caja térmicamente aislada diseñada para capturar la energía solar y de esta forma mantener su interior a una temperatura elevada, o de concentración, en el que mediante un reflector parabólico se concentra la radiación solar en un punto.

\subsubsection{ELEMENTOS CURRICULARES}

\section{OBJETIVOS, CONTENIDOS Y CRITERIOS DE EVALUACIÓN}

Los objetivos, contenidos y criterios de evaluación que se trabajan en esta actividad quedan recogidos en la tabla que se muestra a continuación:

\begin{tabular}{|c|c|c|c|c|}
\hline \multicolumn{2}{|c|}{ OBJETIVOS } & CONTENIDOS & \multicolumn{2}{|c|}{ CRITERIOS DE EVALUACIÓN } \\
\hline $\begin{array}{l}\text { 1. Enumerar } \\
\text { aplicaciones } \\
\text { energía } \\
\text { calefacción, } \\
\text { generación } \\
\text { electricidad }\end{array}$ & $\begin{array}{r}\text { algunas } \\
\text { de la } \\
\text { solar: } \\
\text { cocinar, } \\
\text { de }\end{array}$ & $\begin{array}{l}\text { 1. Las fuentes de energías } \\
\text { renovables: energía solar } \\
\text { y sus aplicaciones. } \\
\text { 2. Ventajas } \\
\text { inconvenientes del uso } \\
\text { de }\end{array}$ & $\begin{array}{l}\text { 1. Enumera } \\
\text { aplicaciones } \\
\text { energía } \\
\text { calefacción, } \\
\text { generación } \\
\text { electricidad }\end{array}$ & $\begin{array}{r}\text { algunas } \\
\text { de la } \\
\text { solar: } \\
\text { cocinar, } \\
\text { de }\end{array}$ \\
\hline
\end{tabular}


caliente.

2. Describir los tres modos de propagación del calor: conducción, convección y radiación.

3. Describir la influencia del efecto invernadero en el horno solar, utilizando un lenguaje científico.

4. Valorar las ventajas de la utilización de energías renovables.

5. Analizar críticamente los inconvenientes de algunas energías renovables (en concreto, de la energía solar).

6. Elaborar un diseño experimental de un horno solar y analizar los resultados.

7. Realizar gráficas que muestren la diferencia de temperatura entre el interior del horno y la temperatura ambiente.

8. Realizar una búsqueda de información sobre los fenómenos que intervienen en el horno solar, sus aplicaciones y ventajas y desventajas, utilizando las TICS y otras fuentes.

9. Respetar las normas de convivencia $y$ comportamiento en el renovables, en concreto de la energía solar.

3. Formas de transferencia del calor: conducción, convección y radiación. Aplicación a los hornos solares.

4. El efecto invernadero.

5. Radiación electromagnética (en concreto, la solar).

6. Funcionamiento y diseño de un horno solar.

7. Construcción de un horno solar.

8. Medida de la temperatura en el interior de un horno solar.

9. Representaciones gráficas de algunas magnitudes físicas.

10. Relación entre la temperatura en el interior de un horno solar y el tiempo de exposición a la luz solar. Análisis e interpretación de resultados.

11. Método científico: generación de hipótesis, toma de datos e interpretación de resultados.

12. Normas de seguridad en un laboratorio. caliente.

2. Describe los tres modos de propagación del calor: conducción, convección y radiación.

3. Describe la influencia del efecto invernadero en el horno solar, utilizando un lenguaje científico.

4. Valora las ventajas de la utilización de energías renovables.

5. Analiza críticamente los inconvenientes de algunas energías renovables (en concreto, de la energía solar).

6. Elabora un diseño experimental de un horno solar y analizar los resultados.

7. Realiza gráficas que muestren la diferencia de temperatura entre el interior del horno y la temperatura ambiente.

8. Realiza una búsqueda de información sobre los fenómenos que intervienen en el horno solar, sus aplicaciones y ventajas y desventajas, utilizando las TICs y otras fuentes.

9. Respeta las normas de convivencia y comportamiento en el aula.

10. Respeta las normas de seguridad en el 


\begin{tabular}{|l|l|}
\hline $\begin{array}{l}\text { aula. } \\
\text { 10. Respetar las normas de } \\
\text { seguridad en el } \\
\text { laboratorio. } \\
\begin{array}{l}\text { 11. Mostrar interés por el } \\
\text { trabajo científico y de } \\
\text { laboratorio. }\end{array}\end{array}$ & $\begin{array}{l}\text { laboratorio. } \\
\text { 11. Muestra interés por el } \\
\text { trabajo científico y de } \\
\text { laboratorio. }\end{array}$ \\
\hline
\end{tabular}

\section{COMPETENCIAS BÁSICAS}

Con esta actividad se contribuye al desarrollo de las siguientes competencias básicas establecidas en el Real Decreto 1631/2006:

CB1. Competencia en comunicación lingüística. Esta competencia se desarrolla porque deben explicar los distintos procesos que se producen en el horno solar utilizando un lenguaje adecuado en las intervenciones de clase.

CB2. Competencia matemática. Los alumnos y alumnas deben interpretar los datos obtenidos en la medición de la temperatura y representarlos en una gráfica.

CB3. Competencia en el conocimiento y la interacción con el mundo físico. Deben realizar observaciones directas del funcionamiento de un horno solar.

CB4. Tratamiento de la información y competencia digital. Deben buscar, obtener, procesar y comunicar información sobre los procesos que intervienen en el horno solar, las posibles aplicaciones así como las ventajas y desventajas.

CB5. Competencia social y ciudadana. El alumnado debe tomar decisiones cuando estén trabajando en grupo y elegir cómo comportarse tanto en las intervenciones en clase como durante el trabajo grupal.

CB8. Autonomía e iniciativa personal. Deben cooperar y trabajar en equipo elaborando el horno solar. Así como dialogar y negociar la organización en la realización del modelo experimental.

\subsubsection{MATERIALES Y RECURSOS}

Dos cajas de diferente tamaño. La pequeña debe caber dentro de la grande y quedar una diferencia de $4 \mathrm{~cm}$ entre las paredes.

Lámina de plástico transparente. 
Lámina o bandeja metálica de color negro mate.

Lámina de cartón.

Papel de periódico.

$>$ Papel de aluminio.

$>$ Cúter, pegamento para papel o cartón o cola, cinta adhesiva, varilla de alambre.

$>$ Olla.

$>$ Termómetro de laboratorio.

\subsubsection{DESCRIPCIÓN DE LA ACTIVIDAD}

\section{1a Parte}

Se dividirán en grupos de 3 o 4 personas dependiendo del número de alumnos y alumnas del grupo-clase. Para comenzar el profesor o la profesora preguntará algunas cuestiones a los alumnos y alumnas y las comentarán cada grupo entre ellos:

- ¿Qué vas a observar con la elaboración del horno solar?

- ¿Qué factores crees que intervienen?

- ¿Piensas que tiene alguna relación el efecto invernadero?

- ¿Crees que se podrá cocinar con la energía solar?

\section{2a Parte}

Después los alumnos y alumnas construirán su propio horno solar. El profesor o profesora les guiará con las pautas que tienen que seguir y los materiales que van a necesitar. Para la elaboración del horno solar se seguirán los siguientes pasos (modificado de [8]):

1) Poner la caja grande boca abajo. Colocar la caja pequeña centrada sobre la caja grande y marcar la silueta que hace sobre ella.

2) Cortar con un cúter el fondo de la caja grande por las líneas marcadas de manera que la caja pequeña se pueda introducir en la caja grande quedando de esta forma una cámara de aire entre las paredes ambas de al menos $4 \mathrm{~cm}$. 
3) Pegar con la cola o pegamento, el papel de aluminio a todas las caras interiores y exteriores de las dos cajas incluidas las tapas y los fondos.

4) Introducir la caja pequeña en el agujero de la caja grande. Ha de quedar bien ajustada.

5) Cortar el sobrante de las tapas de la caja pequeña para que ajusten con las paredes de la caja grande y pegarlas en ésta.

6) Introducir una bandeja o lámina de color negro mate en el fondo interior de la caja pequeña.

7) Dar la vuelta a la caja y rellenar el espacio entre las paredes de las dos cajas con bolas de papel de periódico. Cerrar las tapas de la caja grande con cinta adhesiva.

8) Para confeccionar la tapa utilizar la lámina de cartón. Marcar sobre ella los bordes exteriores e interiores del horno y doblar formando una cubierta que ajuste con el horno.

9) Abrir una ventana abatible y forrarla con papel de aluminio por su parte interna para que refleje más luz al interior del horno.

10) Colocar el plástico transparente en la parte interior de la tapa y pegar con cinta adhesiva para lograr el efecto invernadero.

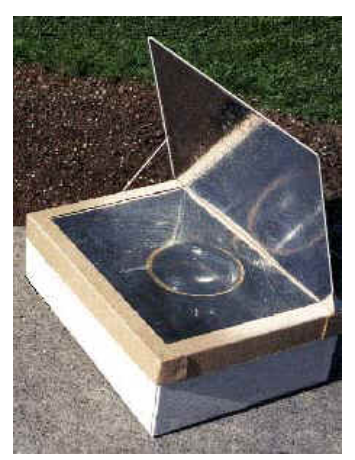

Fig.26. Maqueta de un horno solar [9].

\section{3a Parte}

Los alumnos y alumnas saldrán al patio y pondrán en funcionamiento su horno solar. Para ello van a colocar una olla (preferiblemente de color negro mate) con agua en el interior del horno. La orientarán hacia el sur para captar más luz y deberán sostener la tapa abatible con un alambre con la inclinación adecuada para que refleje la mayor cantidad de luz posible hacia el interior del horno. Cada grupo medirá la 
temperatura en el interior del horno solar y la temperatura ambiente cada cinco minutos durante unos treinta minutos y las anotarán. Se comentarán, en la clase, cuáles han sido los resultados.

\section{4a Parte}

Cada grupo elaborará un informe que incluya una gráfica con los datos tomados que muestre la diferencia de temperaturas entre el exterior e interior del horno solar, en el que se describan los procesos que intervienen, las conclusiones y las posibles aplicaciones así como las ventajas y desventajas. Para completar el informe tendrán que buscar información usando diferentes fuentes, incluidas las tecnologías de la información y comunicación.

\section{DURACIÓN DE LA ACTIVIDAD}

Esta actividad se hará en un total de tres sesiones. Unos 165 minutos aproximadamente.

En la primera sesión se dejará 15 min para que piense, conteste y comente cada grupo las cuestiones planteadas. Después el profesor o profesora explicará el procedimiento para la elaboración del horno solar durante unos 15 minutos y a continuación, los alumnos y alumnas comenzarán a construirlo. La segunda sesión se dedicará completamente para diseñar y construir el horno solar.

Por último, en los primeros 15 minutos de la tercera sesión terminarán los últimos pasos de la construcción del horno solar y saldrán al patio para ponerlo a prueba. Durante 30 minutos tomarán los datos de las temperaturas y los anotarán. En los últimos 10 minutos de la sesión comentarán los resultados y las conclusiones que han sacado. La elaboración del informe se hará como tarea en casa. 


\section{3. ¿PARA QUÉ UTILIZARÍAS LA DESTILACIÓN SOLAR?}

\subsubsection{FUNDAMENTACIÓN}

La destilación es un proceso que puede ser usado para purificar el agua. La destilación solar utiliza la energía del sol para eliminar los contaminantes que tiene el agua no potable ya sean sales, microbios o metales pesados. Este proceso imita a la destilación que se produce, en la naturaleza, a gran escala en el ciclo del agua.

El agua sucia se coloca en un recipiente y se expone a la radiación solar. El calor proveniente del sol evapora el agua produciendo un vapor sin contaminantes que al condensar se convierte en agua líquida destilada.

La destilación solar se puede aplicar a diferentes escalas; ya sea para obtener unos litros de agua al día para abastecer a una familia o en grandes instalaciones para abastecer a una población.

Este sistema puede ser utilizado en países en desarrollo donde no siempre es posible tener agua para consumo en buen estado y de esta forma se evitarían multitud de enfermedades y muertes.

\subsubsection{ELEMENTOS CURRICULARES}

\section{OBJETIVOS, CONTENIDOS Y CRITERIOS DE EVALUACIÓN}

Los objetivos, contenidos y criterios de evaluación que se trabajan en esta actividad quedan recogidos en la tabla que se muestra a continuación:

\begin{tabular}{|c|c|c|}
\hline$\underline{S}$ & CONTENIDOS & CRITERIOS DE EVALUACIÓN \\
\hline $\begin{array}{l}\text { 1. Enumerar las distintas } \\
\text { aplicaciones de la } \\
\text { energía solar. } \\
\text { 2. Explicar en qué consiste } \\
\text { el efecto invernadero y } \\
\text { su relación con el } \\
\text { experimento realizado. } \\
\text { 3. Identificar los }\end{array}$ & $\begin{array}{l}\text { 1. La energía solar y sus } \\
\text { aplicaciones. } \\
\text { 2. El efecto invernadero. } \\
\text { 3. Fases o estados del } \\
\text { agua: líquido y vapor. } \\
\text { 4. Cambios de fase: } \\
\text { evaporación } \\
\text { condensación. }\end{array}$ & $\begin{array}{l}\text { 1. Enumera las distintas } \\
\text { aplicaciones de la } \\
\text { energía solar. } \\
\text { 2. Explica en qué consiste } \\
\text { el efecto invernadero y } \\
\text { su relación con el } \\
\text { experimento realizado. } \\
\text { 3. Identifica los fenómenos }\end{array}$ \\
\hline
\end{tabular}




\begin{tabular}{|c|c|c|}
\hline $\begin{array}{l}\text { fenómenos que } \\
\text { intervienen en la } \\
\text { destilación solar. } \\
\text { 4. Elaborar el diseño } \\
\text { experimental de una } \\
\text { planta de destilación } \\
\text { solar. } \\
\text { 5. Proponer aplicaciones } \\
\text { del experimento } \\
\text { realizado. } \\
\text { 6. Tomar datos a partir del } \\
\text { experimento realizado, } \\
\text { analizarlos, } \\
\text { interpretarlos y extraer } \\
\text { conclusiones, utilizando } \\
\text { un lenguaje científico. } \\
\text { 7. Obtener información } \\
\text { sobre temas científicos, } \\
\text { utilizando distintas } \\
\text { fuentes, incluidas las } \\
\text { tecnologías de la } \\
\text { información y la } \\
\text { comunicación. } \\
\text { Obtener datos sobre las } \\
\text { proporciones de agua } \\
\text { potable en la Tierra. }\end{array}$ & $\begin{array}{l}\text { 5. Ciclo del agua. } \\
\text { 6. Potabilización } \\
\text { depuración del agua. } \\
\text { 7. Destilación. } \\
\text { 8. Relación de la } \\
\text { destilación solar con el } \\
\text { ciclo del agua. } \\
\text { 9. Realización de un } \\
\text { experimento de } \\
\text { destilación solar. } \\
\text { 10. Observación de los } \\
\text { resultados obtenidos en } \\
\text { el experimento con } \\
\text { agua sucia y agua } \\
\text { salada. lo de } \\
\text { 11. Utilización de las } \\
\text { tecnologías de la } \\
\text { información } \\
\text { comunicación para la } \\
\text { búsqueda } \\
\text { información relacionada } \\
\text { con la destilación. } \\
\text { 12. Recursos hídricos: } \\
\text { disponibilidad y uso en } \\
\text { distintos países del } \\
\text { mundo. } \\
\text { 13. El agua potable en el } \\
\text { mundo: relación entre } \\
\text { muertes } \\
\text { enfermedades por la } \\
\text { falta o consumo en mal } \\
\text { estado de ésta. } \\
\text { 14. Soluciones de lemas el mundo. }\end{array}$ & 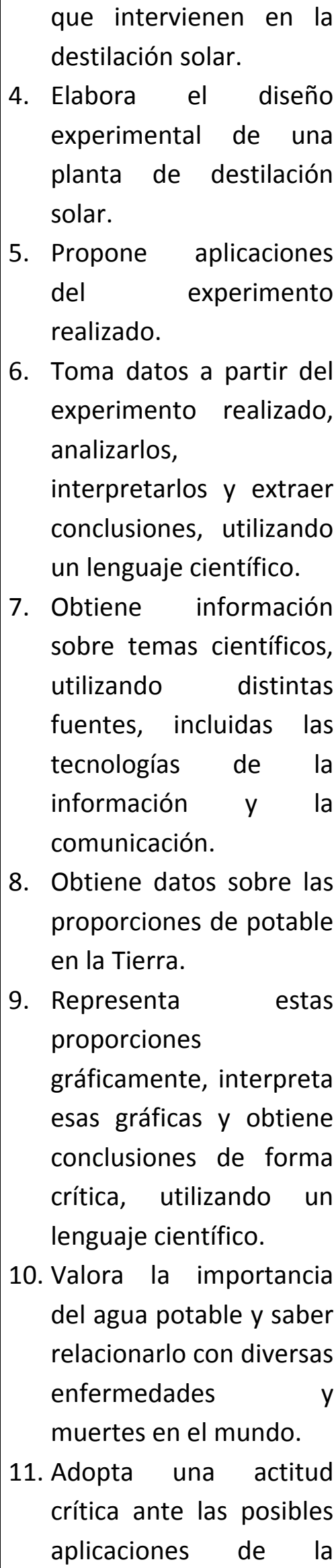 \\
\hline
\end{tabular}




\begin{tabular}{|l|l|}
\hline $\begin{array}{l}\text { crítica ante las posibles } \\
\text { aplicaciones de la } \\
\text { destilación solar para } \\
\text { resolver un problema } \\
\text { mundial. }\end{array}$ & $\begin{array}{l}\text { destilación solar para } \\
\text { resolver un problema } \\
\text { mundial. }\end{array}$ \\
\hline
\end{tabular}

\section{COMPETENCIAS BÁSICAS}

Con esta actividad se contribuye al desarrollo de las siguientes competencias básicas establecidas en el Real Decreto 1631/2006:

CB1. Competencia en comunicación lingüística. Esta competencia se desarrolla porque deben explicar los distintos procesos que se producen en la destilación solar utilizando un lenguaje adecuado en las intervenciones de clase.

CB3. Competencia en el conocimiento y la interacción con el mundo físico. Deben realizar predicciones y observaciones directas del proceso de destilación solar. Así como identificar problemas con la escasez de agua en el mundo y plantear soluciones. Además de ser conscientes de la influencia que tiene la presencia de las personas en el agotamiento de los recursos materiales como el agua.

CB4. Tratamiento de la información y competencia digital. Deben buscar, obtener, procesar y comunicar información sobre cantidad de agua nuestro planeta, la disponible para consumo humano y la relación de esto con numerosas enfermedades.

CB5. Competencia social y ciudadana. El alumnado debe tomar decisiones cuando estén trabajando en grupo y elegir cómo comportarse tanto en las intervenciones en clase como durante el trabajo en grupo.

CB8. Autonomía e iniciativa personal. Deben cooperar y trabajar en equipo elaborando el diseño experimental de una planta de destilación solar. Así como dialogar y negociar la organización en la realización del modelo experimental.

\subsubsection{MATERIALES Y RECURSOS}

$>$ Recipientes de plástico

Film transparente

Vasos pequeños

$>$ Piedras 
Tierra

$>$ Sal

Agua

$>$ Cinta

\subsubsection{DESCRIPCIÓN DE LA ACTIVIDAD}

\section{1a Parte}

Se dividirán los alumnos y alumnas en grupos de 3 o 4 dependiendo del número de alumnado del grupo-clase. Para comenzar se plantearán una serie de cuestiones que los alumnos y alumnas tienen que contestar y comentar antes de realizar el experimento.

- ¿Qué crees que va a pasar?

- ¿Crees que se podrá limpiar agua salada a través de la energía solar?

- ¿Crees que se podrá limpiar agua sucia a través de la energía solar?

- ¿Qué procesos intervienen?

\section{2a Parte}

La mitad de los grupos van a realizar el experimento utilizando agua salada y la otra mitad utilizando agua sucia. Para realizar la destilación solar el procedimiento que tienen que seguir es el siguiente (modificado de [10]):

1) Llenar un recipiente de plástico con dos o tres centímetros de agua. Mezclar la mitad de los grupos de la clase el agua con tierra y la otra mitad con sal.

2) Colocar un vaso vacío en medio del recipiente.

3) Cubrir el recipiente herméticamente con film transparente y sellar con cinta.

4) Poner una piedra pequeña en el centro del film justo encima del vaso vacío pero sin que llegue a tocar.

5) Colocar los recipientes al sol durante unas dos horas. 


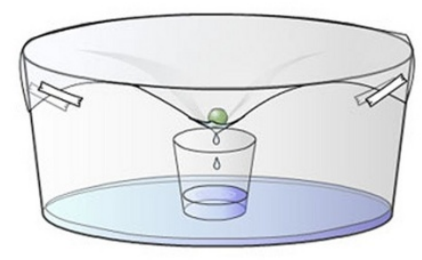

Fig.27. Experimento de destilación solar [11].

\section{3a Parte}

Transcurridas las dos horas, los alumnos y alumnas observarán la cantidad de agua limpia que se ha obtenido en el vaso que estaba vacío y anotarán todas las observaciones realizadas durante el experimento.

Una vez realizado el experimento podrán contestar de nuevo a las preguntas que se les plantearon al principio basándose en su observación y comparar las respuestas entre todo el grupo-clase. Además de las siguientes:

- ¿Podrías explicar lo que has observado?

- ¿¿En qué situaciones podría este experimento salvarte la vida? [10]Explica como lo harías.

\section{4a Parte}

Los alumnos y alumnas tendrán que buscar información en forma de datos o gráficas de la cantidad de agua que hay en nuestro planeta y qué cantidad está disponible para consumo humano. Así como la relación que tiene la falta de agua potable con las muertes y enfermedades que se producen al año en distintos países. Y por último plantearles la pregunta ¿cómo este experimento podría ayudar al problema de la falta de agua potable en el mundo? Tendrán que justificar la pregunta y presentar toda la información individualmente por escrito en forma de trabajo.

\section{DURACIÓN DE LA ACTIVIDAD}

Esta actividad se hará en un total de dos sesiones. Unos 110 minutos aproximadamente.

En la primera sesión se dejarán 15-20 minutos para contestar las preguntas que se plantean en la primera parte y comentarlas. Después se realizará el experimento. 
Transcurridas dos horas entre una sesión y otra, se dedicarán 35 minutos para que los alumnos y alumnas observen los resultados del experimento y comenten las preguntas de la tercera parte. En el resto de la sesión comenzarán con la búsqueda de información que se les plantea, en el aula de informática. La cuarta parte en caso de que no les dé tiempo en clase lo terminarán como tarea en casa.

\subsubsection{ALTERNATIVAS}

\section{ALTERNATIVA 1}

La primera, segunda y tercera parte se mantiene igual y se añadiría una parte en la que se proyectaría un documental titulado "Por un trago de agua" [12], el cual, da una visión de la grave situación que se está viviendo en algunos lugares por la falta de agua y que cada vez se va a ir expandiendo por todo el planeta. Los alumnos y alumnas tendrán que presentar un resumen del documental y contestar a las siguientes preguntas: ¿por qué murió el hermano de Vanesa?, ¿cuántos kilómetros tienen que recorrer cada día para conseguir agua?, ¿por qué no tienen agua?, ¿qué significa para ti la privatización mundial del agua? Después continuaría la cuarta parte anteriormente desarrollada y que de esta forma se convertiría en una quinta parte. 


\section{4. ¿RECURSO ENERGÉTICO ES IGUAL A CONFLICTO?}

\subsubsection{FUNDAMENTACIÓN}

La escasez de agua está llevando a que numerosos países entren en conflicto, pero, ¿es este el único recurso que ha provocado guerras a lo largo de la historia? Como sabemos esto no es así, algunos recursos energéticos como pueden ser el carbón, petróleo, gas natural o el uranio son también motivo de numerosas guerras en todo el mundo debido a su consumo indiscriminado. Pero, ¿estamos hablando de dos problemas o de una solución?

En lo que respecta al acceso a agua potable y a un saneamiento básico, el informe titulado Progress on Sanitation and Drinking-Water 2013, advierte que: "al ritmo actual de progreso, el Objetivo de Desarrollo del Milenio (ODM) para 2015 de reducir a la mitad la proporción de la población que carecía de saneamiento en 1990 no se alcanzará por un 8\%, una cifra que representa 500 millones de personas" [13].

Alrededor de 2,4 millones de personas es decir, un tercio de la población mundial, seguirán sin tener acceso a un saneamiento mejorado en 2015, según un informe conjunto de la OMS y UNICEF.

Los datos publicados en 2013, según los cálculos estimados de la Organización Mundial de la Salud (OMS) y UNICEF, indican que en el mundo hay 768 millones de personas que carecen de acceso a agua potable, y debido a ello cada año se enferman y mueren cientos de miles de niños. UNICEF calcula que 1.400 niños menores de cinco años mueren diariamente de enfermedades relacionadas con la falta de agua potable, saneamiento adecuado e higiene[14].



Fig.28. Escasez física y/o económica de agua a nivel mundial [15]. 


\subsubsection{ELEMENTOS CURRICULARES}

\section{OBJETIVOS, CONTENIDOS Y CRITERIOS DE EVALUACIÓN}

Los objetivos, contenidos y criterios de evaluación que se trabajan en esta actividad quedan recogidos en la tabla que se muestra a continuación:

\begin{tabular}{|c|c|c|}
\hline & $\underline{S}$ & IÓN \\
\hline $\begin{array}{l}\text { 1. Buscar información sobre } \\
\text { los conflictos existentes } \\
\text { en la actualidad a nivel } \\
\text { mundial, provocados por } \\
\text { los recursos energéticos } \\
\text { (petróleo, carbón, gas } \\
\text { natural y uranio) y por } \\
\text { recursos materiales } \\
\text { (agua). la situación } \\
\text { 2. Describir la de } \\
\text { actual sobre la escasez de } \\
\text { agua potable aportando } \\
\text { datos sobre los conflictos, } \\
\text { causas, consecuencias y } \\
\text { principales dificultades } \\
\text { para el abastecimiento en } \\
\text { algunos países. } \\
\text { 3. Seleccionar información } \\
\text { científica con sentido } \\
\text { crítico utilizando las TICs y } \\
\text { otras fuentes. } \\
\text { 4. Diseñar y construir una } \\
\text { maqueta que trate de } \\
\text { aportar alguna solución } \\
\text { para el transporte de } \\
\text { agua potable en países } \\
\text { subdesarrollados, } \\
\text { utilizando fuentes de } \\
\text { energía renovables. }\end{array}$ &  & $\begin{array}{l}\text { 1. Busca información sobre } \\
\text { los conflictos existentes } \\
\text { en la actualidad a nivel } \\
\text { mundial, provocados por } \\
\text { los recursos energéticos } \\
\text { (petróleo, carbón, gas } \\
\text { natural y uranio) y por } \\
\text { recursos materiales } \\
\text { (agua). pituación } \\
\text { 2. Describe la scasez } \\
\text { actual sobre la escasez } \\
\text { de agua potable } \\
\text { aportando datos sobre } \\
\text { los conflictos, causas, } \\
\text { consecuencias } \\
\text { principales dificultades } \\
\text { para el abastecimiento } \\
\text { en algunos países. } \\
\text { 3. Selecciona información } \\
\text { científica con sentido } \\
\text { crítico utilizando las TICs } \\
\text { y otras fuentes. } \\
\text { 4. Eiseña y construye una } \\
\text { maqueta que trate de } \\
\text { aportar alguna solución } \\
\text { para el transporte de } \\
\text { agua potable en países } \\
\text { subdesarrollados, } \\
\text { utilizando fuentes de } \\
\text { energía renovables. }\end{array}$ \\
\hline
\end{tabular}




\begin{tabular}{|c|c|c|}
\hline 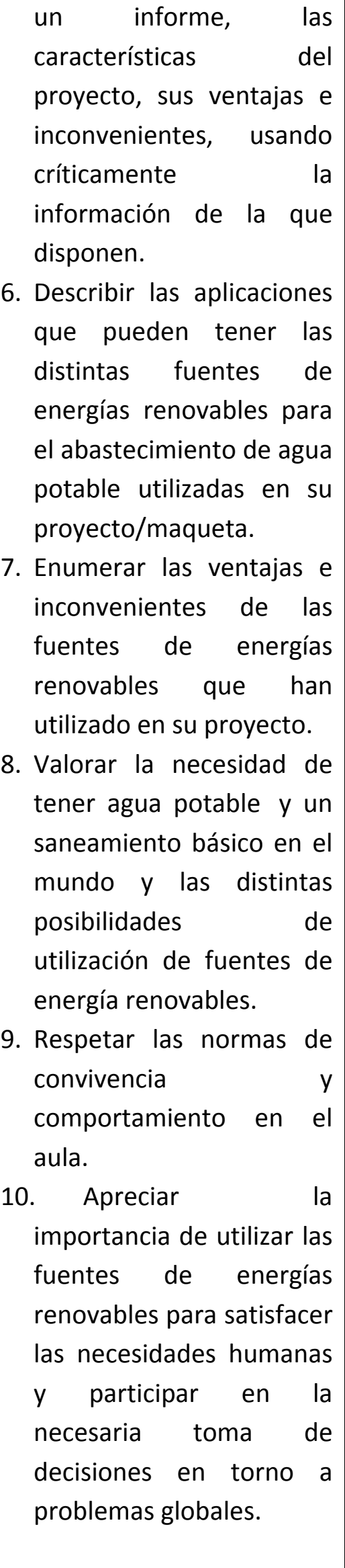 & $\begin{array}{l}\text { conciencia de la } \\
\text { necesidad de agua } \\
\text { potable y } \\
\text { saneamiento básico } \\
\text { en el mundo. } \\
\text { 11. Potabilización, } \\
\text { depuración, transporte } \\
\text { y distribución del agua } \\
\text { potable. } \\
\text { 12. Propuesta de medidas } \\
\text { para el cuidado de los } \\
\text { recursos hídricos. } \\
\text { 13. Utilización correcta de } \\
\text { los materiales y } \\
\text { respeto por las normas } \\
\text { de seguridad. } \\
\text { 14. Valoración de las } \\
\text { interacciones de la } \\
\text { ciencia y la tecnología } \\
\text { con la sociedad y el } \\
\text { medio ambiente. }\end{array}$ & $\begin{array}{l}\text { mediante la realización } \\
\text { de un informe, las } \\
\text { características del } \\
\text { proyecto, sus ventajas e } \\
\text { inconvenientes, usando } \\
\text { críticamente la } \\
\text { información de la que } \\
\text { disponen. } \\
\text { 6. Describe las aplicaciones } \\
\text { que pueden tener las } \\
\text { distintas fuentes de } \\
\text { energías renovables para } \\
\text { el abastecimiento de } \\
\text { agua potable utilizadas } \\
\text { en su proyecto/maqueta. } \\
\text { 7. Enumera las ventajas e } \\
\text { inconvenientes de las } \\
\text { fuentes de energías } \\
\text { renovables que han } \\
\text { utilizado en su proyecto. } \\
\text { 8. Valora la necesidad de } \\
\text { tener agua potable y un } \\
\text { torno aprecia la importancia de } \\
\text { utilizar las fuentes de } \\
\text { energías renovables para } \\
\text { satisfacer } \\
\text { necesidades humanas y } \\
\text { participar en la necesaria } \\
\text { mundo y las distintas } \\
\text { posibilidades decisiones en } \\
\text { utilización de fuentes de } \\
\text { energía renovables. } \\
\text { convivencia }\end{array}$ \\
\hline
\end{tabular}




\section{COMPETENCIAS BÁSICAS}

Con esta actividad se contribuye al desarrollo de las siguientes competencias básicas establecidas en el Real Decreto 1631/2006:

CB1. Competencia en comunicación lingüística. Esta competencia se desarrolla porque deben expresar e interpretar mapas, gráficas, tablas, etc. sobre los recursos energéticos y el recurso material del agua. Además de saber comunicarse utilizando un lenguaje adecuado en las intervenciones de clase.

CB3. Competencia en el conocimiento y la interacción con el mundo físico. Los alumnos y alumnas deben identificar los problemas existentes con los recursos energéticos e hídricos, y plantear una solución de ambos. Además, deben interpretar la información que el profesor o profesora muestra sobre la escasez de agua para tomar decisiones con iniciativa y buscar soluciones con el desarrollo de una maqueta e informe.

CB4. Tratamiento de la información y competencia digital. Deben buscar, obtener, procesar y comunicar información sobre los conflictos por recursos energéticos y materiales (concretamente, hídricos), así como las causas, consecuencias y las principales dificultades para obtener el agua en esos países.

CB5. Competencia social y ciudadana. El alumnado debe tomar decisiones cuando estén trabajando en grupo y elegir cómo comportarse tanto en las intervenciones en clase como durante el trabajo en grupo.

CB6. Competencia cultural y artística. Deben tener iniciativa, imaginación y creatividad para elaborar tanto el mural con los conflictos energéticos como para la maqueta.

CB8. Autonomía e iniciativa personal. Deben cooperar y trabajar en equipo elaborando el mural y la maqueta. Así como dialogar y negociar la organización en la realización del proyecto.

\subsubsection{MATERIALES Y RECURSOS}

- Aula de tecnología y aula de informática.

- Ordenadores.

- Los materiales para la maqueta serán a libre elección de los alumnos y alumnas. 


\subsubsection{DESCRIPCIÓN DE LA ACTIVIDAD}

\section{1․ Parte}

El profesor o profesora comenzará preguntando ¿pensáis que los recursos energéticos pueden ser motivo de una guerra? ¿Qué recursos energéticos han provocado algún conflicto en la historia? ¿Conocéis alguna? Tras la lluvia de ideas en clase los alumnos y alumnas van a realizar un mural. Se van a dividir en cuatro grupos y cada uno va a escoger un recurso para investigar; carbón, petróleo, gas y uranio. En cada mural tendrán que representar un mapa del mundo con los conflictos que se han producido y se está produciendo por los recursos energéticos con una escala en el tiempo. Después se les preguntará: ¿Pensáis que los recursos energéticos son solo motivo de guerra o puede ser solución a un problema?

\section{$\underline{\underline{\text { a }} \text { Parte }}$}

Se les enseñarán a los alumnos y alumnas las imágenes que se muestran a continuación:

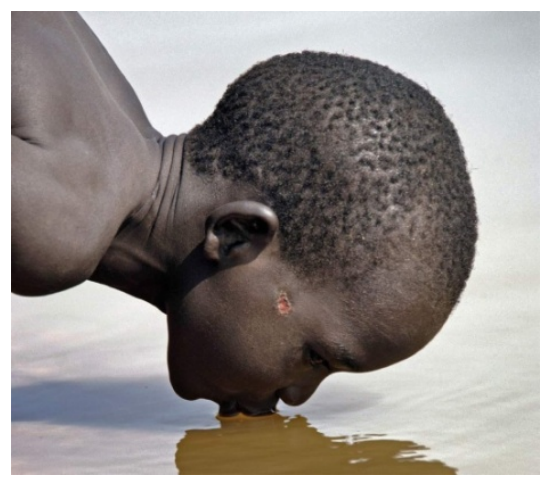

Fig. 29. Niño bebiendo agua

(país con escasez de agua) [16].

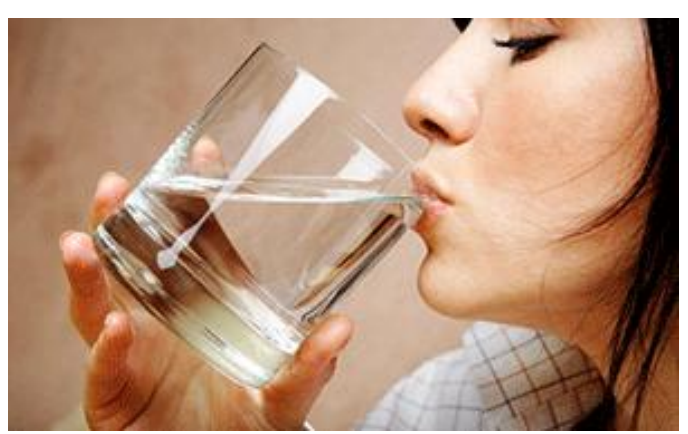

Fig.30. Mujer bebiendo agua (país sin escasez de agua) [17].

Se realizará una lluvia de ideas y se les harán las siguientes preguntas: ¿Qué podéis ver en estas dos imágenes?, ¿de qué creeis que estamos hablando?, ¿existen algunas diferencias?, ¿cuáles?.

Después el profesor o profesora proyectará un vídeo ([18]) con algunas noticias relacionadas con la escasez de agua. Además, mostrará las siguientes imágenes con información sobre el agua potable en el mundo, procedentes de [19]. 


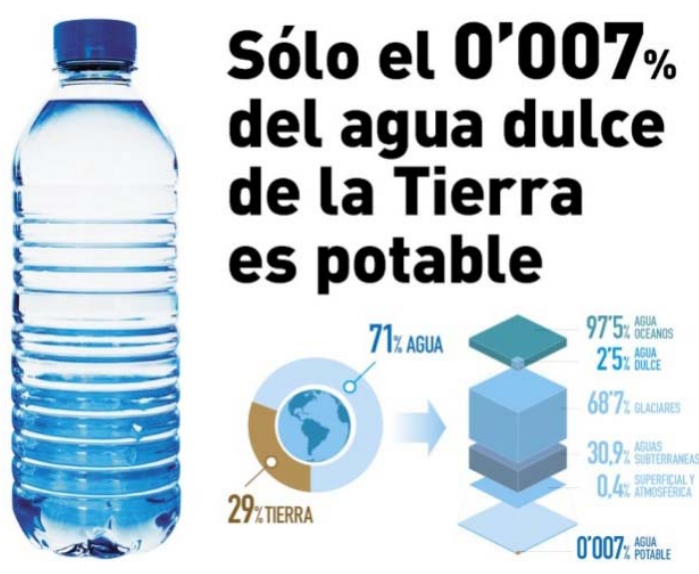

Fig.31. Distribución del agua en la Tierra [19].
Además, existe una desigual distribución entre la población y los recursos hídricos a nivel mundial.



Fig.32. Desigual distribución de los recursos Hídricos [19].

\section{3a Parte}

Los alumnos y alumnas, por parejas, tendrán que buscar información sobre los conflictos que se están produciendo en el mundo a consecuencia de la falta de agua potable, sobre sus causas, consecuencias y las principales dificultades para su obtención en esos países. Se deben de apoyar de gráficas, tablas y datos que corroboren la situación actual en el mundo sobre este recurso. Para ello, utilizarán diferentes fuentes incluidas las tecnologías de la información y comunicación.

\section{4a Parte}

Se les presenta la siguiente noticia de prensa [20] (noticia completa en el anexo II: Recursos del Banco de Actividades):

\section{"Niños de Níger faltan a la escuela para buscar agua"}

"Como la baja precipitación pluvial ha secado al campo, la búsqueda de agua se ha vuelto cada vez más difícil. La tarea de conseguir agua frecuentemente recae en los niños de Níger, algunos de apenas 10 u 11 años de edad. A lomos de burros se alejan hasta ocho kilómetros de la localidad, con gigantescas garrafas de plástico de la mitad de su altura atadas a los costados de los animales".

"Oumaraou Lawali, de 11 años de edad, abrió mucho los ojos y explicó cómo se había despertado a las 4:30 de la mañana para caminar cinco kilómetros en busca de agua; posteriormente, después de clases, repetiría el viaje. "En las noches, estoy cansado", dijo. "Agotado". 
Después se les planteará la siguiente hipótesis: con motivo de la situación que se esta viviendo, el gobierno de Níger ha decretado el estado de emergencia y hace un llamamiento, solicitando a los países desarrollados ayuda para solventar el problema. Es por ello que pide a los gobiernos, ciudadanos, estudiantes, etc. que presenten proyectos para abastecer a esos niños de agua a través de la utilización de fuentes de energía renovables. Se les preguntará:

¿se os ocurre alguna solución? ¿créis que se podrían utilizar algunas fuentes de energía?

\section{5a Parte}

Se dividirán en grupos de 4 o 5 personas dependiendo del número de alumnado en el grupo-clase y tendrán que presentar un proyecto en forma de maqueta. En éste tendrá que quedar reflejado: las distintas fuentes de energía que se utilizarían, tanto para la obtención del agua, como para el transporte, potabilización y distribución a las viviendas. Presentarán un informe explicando cómo se afrontarían cada uno de estos pasos, e incluirán cuales son las ventajes e inconvenientes de las fuentes de energía renovables que han utilizado. Una vez terminado, cada grupo tendrá que defender su proyecto en la clase.

\section{DURACIÓN DE LA ACTIVIDAD}

Esta actividad se hará en un total de 5 sesiones. Unos 275 minutos aproximadamente.

La primera sesión se dedicará completamente para realizar la primera parte de la actividad. La segunda sesión se dividirá en 30 minutos para la segunda parte, donde se presentarán las imágenes, se realizará la lluvia de ideas, y se verán el video y los datos presentados por el profesor o profesora; y los 25 minutos restantes se dedicarán a la tercera parte. Si no terminan, seguirán buscando la información en casa como tarea. En la tercera sesión se presentarán la noticia, la hipótesis y las preguntas de la cuarta parte en los primeros 35 minutos, y el resto de la sesión comenzarán a buscar información necesaria para su maqueta, divididos en pequeños grupos. En la cuarta sesión realizarán la maqueta. En casa tendrán que terminarla en caso de que no les dé 
tiempo y realizar el informe. En la quinta sesión los alumnos y alumnas presentarán sus maquetas al resto de los compañeros.

\subsubsection{ALTERNATIVAS}

\section{ALTERNATIVA 1}

El desarrollo de la actividad será como viene indicado anteriormente pero se añadirá una parte más en la que los alumnos y alumnas tendrán que presentar sus proyectos/maquetas durante la semana de la ciencia a los profesores y el alumnado del centro. El profesorado del departamento de Biología y Geología elegirá el mejor de los proyectos.

\section{ALTERNATIVA 2}

Las actividad se desarrollará tal cual está explicada pero en la cuarta parte se añadirá un documental titulado "Por un trago de agua" ([12]) que nos ofrece una visión de la grave situación que se está viviendo en algunos lugares por la falta de agua, y que previsiblemente se extenderá por todo el planeta en años venideros. Los alumnos y alumnas tendrán que presentar las ideas principales que han ido obteniendo, tras visualizar el documental. 


\section{5. ¿CUÁNTA ENERGÍA HAY EN LA COMIDAD DE MARTA?}

\subsubsection{FUNDAMENTACIÓN}

Según el último informe titulado La Energía de España 2012 [21], los indicadores de consumo energético a nivel global continúan manteniendo una tendencia al alza. En lo que respecta al consumo de los combustibles fósiles, el carbón es el que más rápido está creciendo, siendo China el mayor consumidor mundial. El consumo de gas natural sigue creciendo, y aun así, ha seguido siendo el petróleo la energía primaria más utilizada en el mundo durante el 2012. Este mismo año, por otra parte, se produjo la mayor caída en la producción de energía nuclear.

En cuanto a las energías renovables, la demanda mundial continuó aumentado durante el 2012. "En la generación de electricidad contribuyeron al mix en un 4,7\% de la generación eléctrica mundial y el total de la potencia instalada de energía renovable en todo el mundo superó los 1.270 GW en 2012" [21].

En el 2012, el consumo de energía total en España fue de 89.9349 Ktep (tep: tonelada equivalente de petróleo). La demanda de energía eléctrica disminuido con respecto al año anterior. En lo que respecta a los combustibles fósiles, hay que destacar que el consumo de productos petrolíferos ha disminuido, mientras que se ha producido un aumento en el consumo de gas. Las aportaciones de las energías renovables han tenido un notable crecimiento durante este año, sin contar con la energía hidroeléctrica que ha decrecido debido años secos.

\subsubsection{ELEMENTOS CURRICULARES}

\section{OBJETIVOS, CONTENIDOS Y CRITERIOS DE EVALUACIÓN}

Los objetivos, contenidos y criterios de evaluación que se trabajan en esta actividad quedan recogidos en la tabla que se muestra a continuación:

\begin{tabular}{|c|c|c|}
\hline OBJETIVOS & CONTENIDOS & CRITERIOS DE EVALUACIÓN \\
\hline $\begin{array}{l}\text { 1. Identificar distintas } \\
\text { fuentes de energía, y }\end{array}$ & $\begin{array}{l}\text { 1. Las fuentes de } \\
\text { energía: renovables y }\end{array}$ & $\begin{array}{l}\text { 1. Identifica distintas } \\
\text { fuentes de energía, y las }\end{array}$ \\
\hline
\end{tabular}




\begin{tabular}{|c|c|c|c|}
\hline 6. & 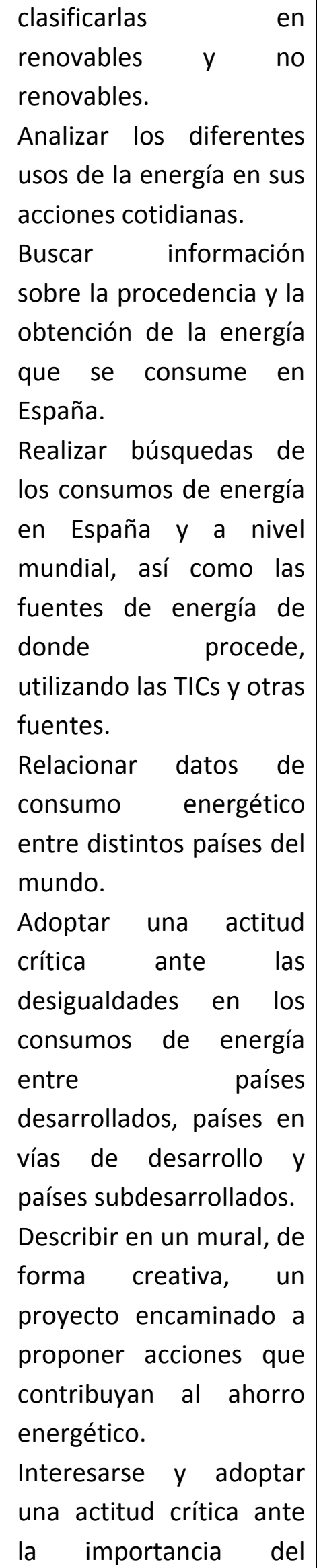 & 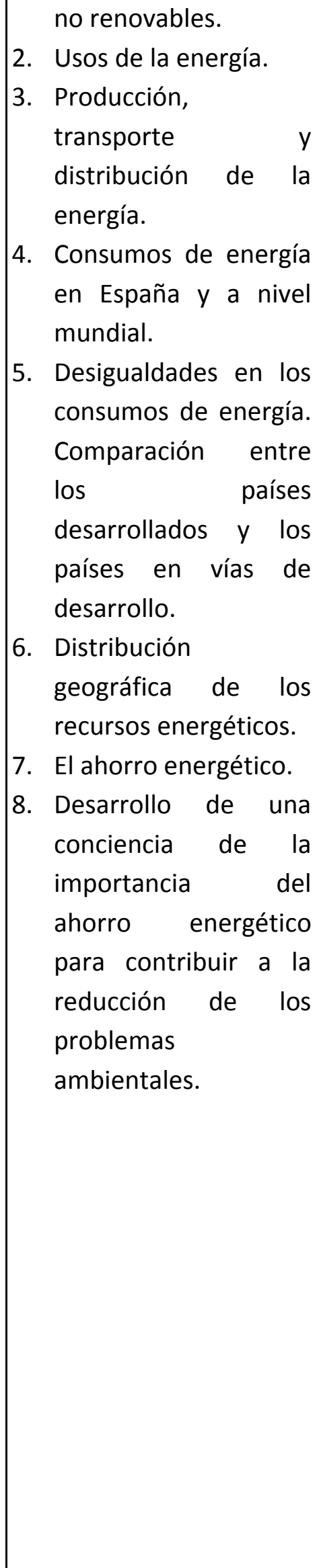 & 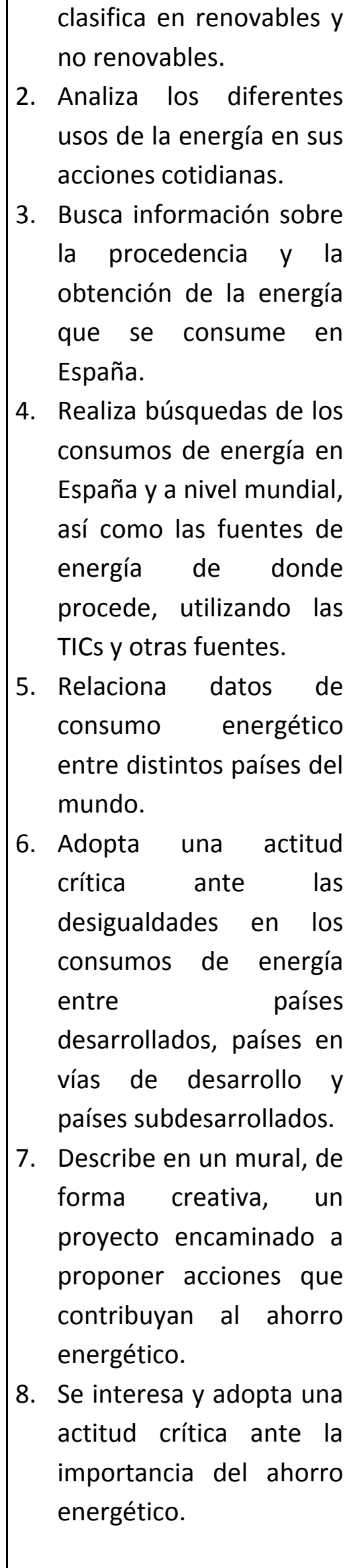 \\
\hline
\end{tabular}


ahorro energético.

\section{COMPETENCIAS BÁSICAS}

Con esta actividad se contribuye al desarrollo de las siguientes competencias básicas establecidas en el Real Decreto 1631/2006:

CB1. Competencia en comunicación lingüística .Esta competencia se desarrolla porque deben comunicar los resultados de sus búsquedas de información acerca de las fuentes de energía y su uso. Además de saber comunicarse y dialogar durante la lluvia de ideas.

CB2. Competencia matemática. Los alumnos y alumnas deben utilizar y relacionar los números para calcular la energía que consume Marta y su emisión equivalente total de $\mathrm{CO}_{2}$. También deben interpretar y representar la realidad sobre los consumos a nivel mundial de energía y las diferencias entre países a partir de la información incluida en las tablas y gráficas.

CB3. Competencia en el conocimiento y la interacción con el mundo físico. Deben identificar los problemas con respecto al consumo de energía y plantear soluciones. Además deben ser conscientes de la influencia que tienen sus acciones en el Medio Ambiente perseguir la conservación de los recursos energéticos.

CB4. Tratamiento de la información y competencia digital. Deben buscar, obtener, procesar y comunicar información sobre la cantidad de energía que se usa en España y de donde proviene y los consumos de energía a nivel mundial.

CB5. Competencia social y ciudadana. El alumnado debe tomar decisiones cuando estén trabajando en grupo y elegir cómo comportarse tanto en las intervenciones en clase como durante el trabajo grupal.

CB6. Competencia cultural y artística. Deben ser imaginativos y creativos a la hora de elaborar el mural con las acciones que realizarían para ahorrar energía utilizando slogan, imágenes, dibujos, etc.

CB8. Autonomía e iniciativa personal. Deben cooperar y trabajar en equipo elaborando el mural y la presentación, así como dialogar y negociar la organización en la realización del trabajo. 


\subsubsection{MATERIALES Y RECURSOS}

- Aula de informática.

- Ordenador, proyector.

- Fotocopias de la noticia de prensa.

- Cartulinas.

- Rotuladores de colores.

7.5.4. DESCRIPCIÓN DE LA ACTIVIDAD (planteada según propuesta de García et al., (2007))

\section{1a Parte}

Para comenzar el profesor o la profesora preguntará a los alumnos y alumnas:

¿Qué energía estamos usando ahora mismo en nuestra clase? después se presentará la imagen que se muestra a continuación y se les preguntará, ¿qué fuentes de energía reconocéis en la siguiente imagen? Se pretende que los alumnos y alumnas realicen una lluvia de ideas.

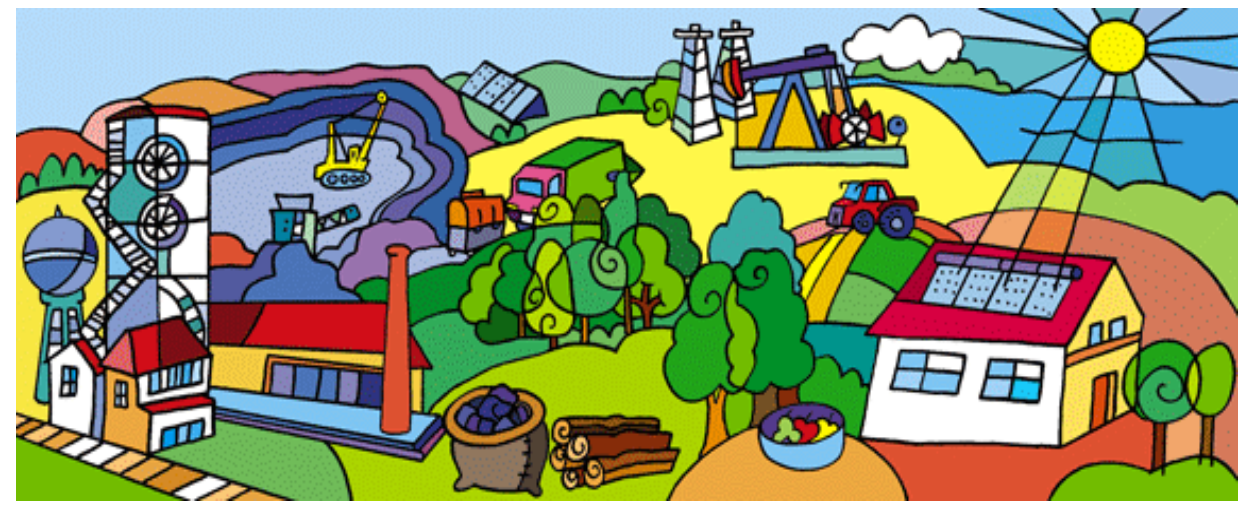

Fig.33.Dibujo representativo de diversas fuentes de energía [22].

\section{2a Parte}

Se planteará la siguiente situación:

Marta por la mañana se prepara un zumo de naranja con unas tostadas y un vaso de leche caliente antes de ir al instituto. Cuando vuelve hambrienta de clase se cocina unos filetes con unas patatas fritas. Por la noche para ver su serie favorita, se prepara una pizza y después de todo el día pone el lavavajillas para recoger la cocina. 
Se les pedirá que contesten a las siguientes preguntas: ¿Cuánta energía consume Marta en sus tres comidas?, ¿Cuál es su emisión equivalente total de $\mathrm{CO}_{2}$ ?. Cada alumno o alumna rellenará la columna del tiempo según considere.

Tabla I. Ejercicio para rellenar por el alumnado.

\begin{tabular}{|c|c|c|c|}
\hline Tiempo(Horas) & Electrodoméstico & Potencia (W) & $\begin{array}{l}\text { Consumo por } \\
\text { aparato }(\mathbf{W} \cdot h)\end{array}$ \\
\hline & Exprimidor & $25 \mathrm{~W}$ & \\
\hline & Tostadora & $500 \mathrm{~W}$ & \\
\hline & Microondas & $1200 \mathrm{w}$ & \\
\hline & Fogón de inducción & $2200 \mathrm{~W}$ & \\
\hline & Freidora & $1000 \mathrm{~W}$ & \\
\hline & Horno eléctrico & $1200 \mathrm{~W}$ & \\
\hline & Lavavajillas & $800 \mathrm{~W}$ & \\
\hline \multicolumn{4}{|c|}{ Total del consumo } \\
\hline \multicolumn{3}{|c|}{ Factor de emisión } & $0,385 \mathrm{Kg} / \mathrm{Kw} \cdot \mathrm{h}[23]$ \\
\hline \multicolumn{3}{|c|}{ EMISIONES DE $\mathrm{CO}_{2}$ DE MARTA } & \\
\hline
\end{tabular}

\section{3a Parte}

Los alumnos y alumnas tendrán que recapitular todas las acciones que realizan a lo largo del día y que requieran energía. Para mostrar esta información se van a dividir en varios grupos de 4 o 5 alumnos y alumnas y van a elaborar una presentación (por ejemplo en Power Point o el programa que consideren oportuno). Por un lado van a poner las acciones que realizan a lo largo del día que tiene gasto de energía y las van a relacionar con las fuentes de energía de donde proceden. Además tendrán que buscar información, utilizando diferentes fuentes incluidas las tecnologías de la información y comunicación, sobre la cantidad de energía que usamos en España, cuáles son las principales fuentes de energía que se utilizan, cómo se obtiene, es decir, producción, transporte y distribución y de dónde proceden esos recursos energéticos. Deberán aportar gráficas, tablas, datos, etc. Toda esta información debe quedar plasmada en la presentación, y cada grupo lo expondrá en la clase. 


\section{4a Parte}

Se mostrarán las siguientes imágenes y se comentará que en la primera imagen aparece Keyah, una niña de Mozambique preparando la comida para su familia y en la segunda imagen se muestra la cocina de Marta. Se les plantearán las siguientes cuestiones para que debatan en la clase:

- ¿Qué diferencias existen entre ambas imágenes?

- ¿Creéis que consumen la misma energía Marta y Keyah?

- ¿De qué fuentes de energía proviene la energía que utiliza cada una para cocinar?

- ¿Son necesarios todos los electrodomésticos que usa Marta?

- ¿Cuáles son las consecuencias del despilfarro de energía?

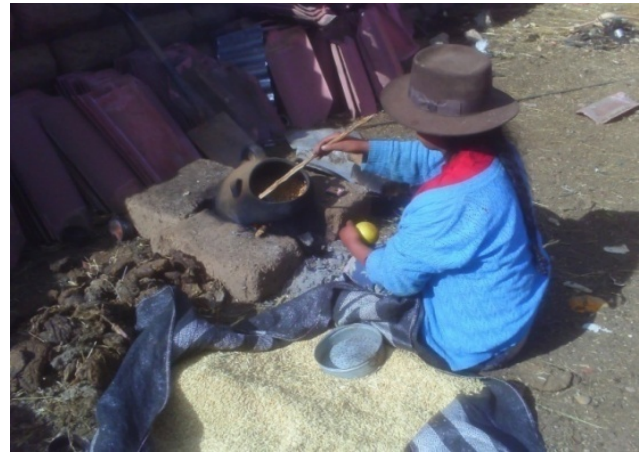

Fig.34. Keyah cocinando [24].

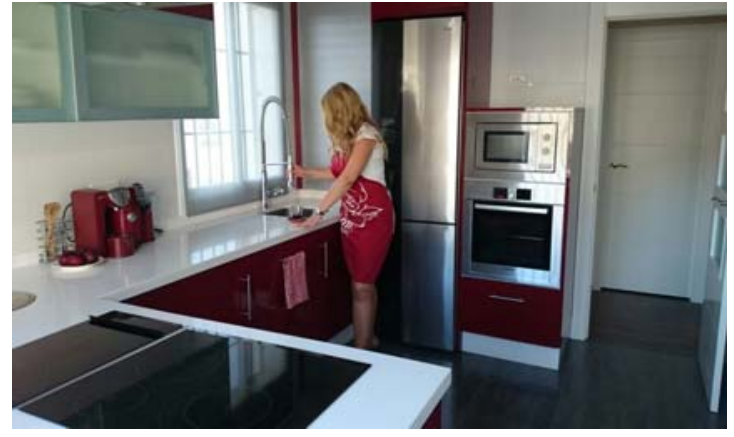

Fig.35. Marta cocinando.

Cada grupo tendrá que buscar información sobre los consumos de energía de varios países del mundo (desarrollados, en vías de desarrollo y subdesarrollados) incluyendo las fuentes de energía más utilizadas. Tendrán que presentar una tabla donde se compare el consumo de energía en los países desarrollados y en los países en vías de desarrollo y aportar gráficas, planos o tablas que podrán obtener del Google Data Public Explorer (ejemplo en el Anexo II). Además presentarán un mapa del mundo con la distribución de los recursos energéticos.

\section{5a Parte}

Por último, cada grupo tendrá que elaborar un mural en el que aparezcan las acciones que pueden realizar a lo largo del día para ahorrar energía. Se tendrá en cuenta la creatividad a la hora de realizarlo, que incluya imágenes, dibujos, un slogan, 
etc., y un diseño visual atractivo que centre la atención del resto del alumnado, puesto que se van a exponer en distintas dependencias del centro.

\section{DURACIÓN DE LA ACTIVIDAD}

Esta actividad se hará en un total de 4 sesiones. Unos 220 minutos aproximadamente.

De la primera sesión se dedicará 25 minutos a la primera parte y 30 minutos a la segunda parte. Las presentaciones de la tercera parte tendrán que traerlas elaborados como tarea. De esta forma, en la segunda sesión se realizarán las exposiciones. La tercera sesión se dividirá en 25 minutos para presentar las imágenes, debatir y contestar a las preguntas que se plantean en la cuarta parte y 30 minutos para investigar los consumos de energía a nivel mundial, en caso de que no les dé tiempo, lo terminaran en casa. La cuarta sesión se dejará completa para realizar la quinta parte.

\subsubsection{ALTERNATIVAS}

\section{ALTERNATIVA 1}

El desarrollo de la 1a $, 3 \underline{a}, 4$ y $5^{a}$ partes se mantiene igual y la segunda parte se podría complementar haciendo un cálculo de la cantidad equivalente de $\mathrm{CO}^{2}$ que consumen cada alumno y alumna en un año. Para ello tendrán que buscar todas las facturas de energía eléctrica que tengan en sus casa de un año y hacer un cálculo de lo que consumen dividiendo por el número de personas de la vivienda. Después aplicarán el factor de emisión aportado anteriormente. 


\section{6. "TU PROGRAMA DE ENERGÍA"}

\subsubsection{FUNDAMENTACIÓN}

Un podcast es un archivo de audio o de video al que podemos acceder mediante suscripción RSS y que se puede escuchar o visualizar on-line o bien descargarlo para tenerlo en el mp3, en el móvil o en el ordenador. De esta forma los alumnos y alumnas podrán estudiar o trabajar a través de los podcast en cualquier momento. Y también permitirá al resto del alumnado del centro disponer de ellos.

De acuerdo con Solano y Sánchez (2009), "el diseño de archivos de audio o video por parte de los alumnos permite que éstos se conviertan en fuente activa del proceso de enseñanza-aprendizaje publicando y editando contenidos en diferentes formatos, $y$ lo más importante de forma colaborativa, utilizando estrategias como el estudio de casos, el aprendizaje basado en problemas y proyectos, etc." (p. 136).

\subsubsection{ELEMENTOS CURRICULARES}

\section{OBJETIVOS, CONTENIDOS Y CRITERIOS DE EVALUACIÓN}

Los objetivos, contenidos y criterios de evaluación que se trabajan en esta actividad quedan recogidos en la tabla que se muestra a continuación:

\begin{tabular}{|c|c|c|}
\hline OBJETIVOS & CONTENIDOS & $\begin{array}{l}\text { CRITERIOS DE } \\
\text { EVALUACIÓN }\end{array}$ \\
\hline $\begin{array}{l}\text { 1. Describir las fuentes de } \\
\text { energía no renovables: } \\
\text { carbón, petróleo, gas } \\
\text { natural y nuclear. } \\
\text { 2. Describir las fuentes de } \\
\text { energía renovables: solar, } \\
\text { eólica, geotérmica, } \\
\text { biomasa, hidráulica, } \\
\text { marítima y el vector } \\
\text { energético del hidrógeno. } \\
\text { 3. Enumerar los distintos } \\
\text { usos de cada una de las }\end{array}$ & $\begin{array}{l}\text { 1. Las fuentes de energía } \\
\text { no renovables } \\
\text { 2. Las fuentes de energía } \\
\text { renovables. } \\
\text { 3. Usos de la energía. } \\
\text { 4. Producción, transporte y } \\
\text { distribución de la energía. } \\
\text { 5. Límite de las fuentes de } \\
\text { energías no renovables. } \\
\text { 6. Ventajas }\end{array}$ & $\begin{array}{l}\text { 1. Describe las fuentes de } \\
\text { energía no renovables: } \\
\text { carbón, petróleo, gas } \\
\text { natural y nuclear. } \\
\text { 2. Describe las fuentes de } \\
\text { energía renovables: solar, } \\
\text { eólica, geotérmica, } \\
\text { biomasa, hidráulica, } \\
\text { marítima y el vector } \\
\text { energético del hidrógeno. } \\
\text { 3. Enumera los distintos } \\
\text { usos de cada una de las }\end{array}$ \\
\hline
\end{tabular}




\begin{tabular}{|c|c|c|}
\hline 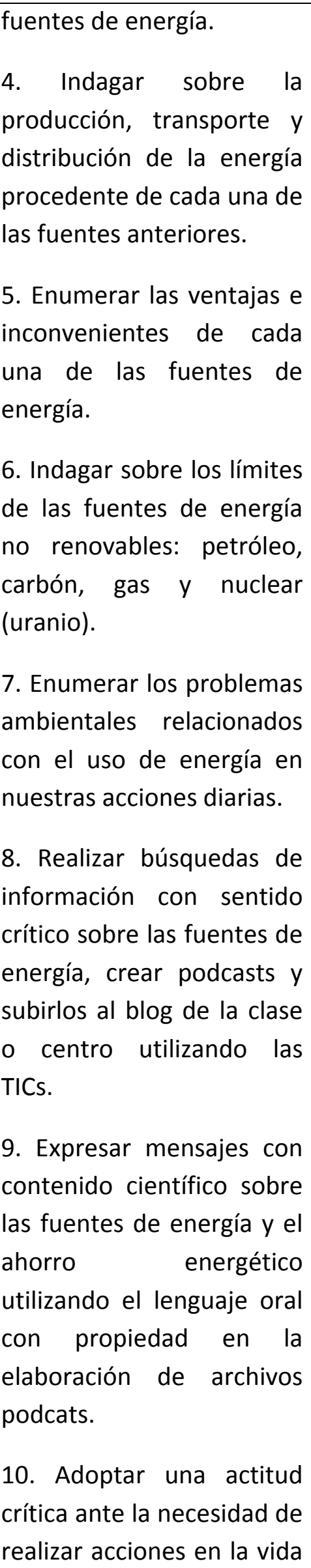 & $\begin{array}{l}\text { inconvenientes de las } \\
\text { fuentes de energía. } \\
\text { 7. Problemas ambientales } \\
\text { relacionados con el uso de } \\
\text { energía. } \\
\text { 8. Edición de podcasts con } \\
\text { contenido sobre las } \\
\text { fuentes de energía y el } \\
\text { ahorro energético. } \\
\text { 9. Elaboración de un } \\
\text { apartado en el blog de la } \\
\text { clase o centro para subir } \\
\text { archivos podcast. } \\
\text { 10. El ahorro energético. }\end{array}$ & 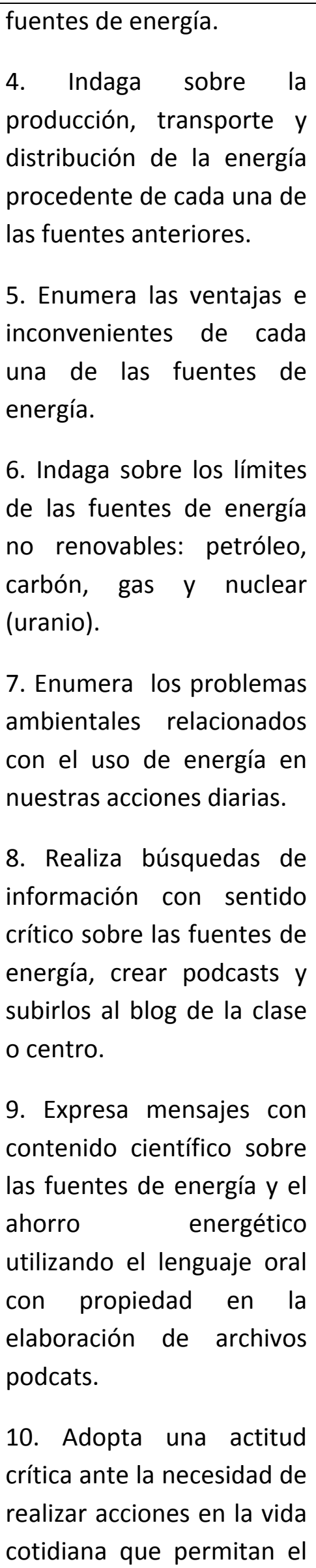 \\
\hline
\end{tabular}


cotidiana que permitan el ahorro energético.

\section{COMPETENCIAS BÁSICAS}

Con esta actividad se contribuye al desarrollo de las siguientes competencias básicas establecidas en el Real Decreto 1631/2006:

CB1. Competencia en comunicación lingüística. Esta competencia se desarrolla porque deben describir las fuentes de energía y realizar entrevistas utilizando un lenguaje adecuado en la edición de los podcasts.

CB3. Competencia en el conocimiento y la interacción con el mundo físico. Los alumnos y alumnas deben identificar los problemas ambientales relacionados con el uso de la energía, así como los límites de las fuentes de energía no renovables y plantear soluciones. Además de ser conscientes en la influencia que tiene la presencia de las personas en el Medio Ambiente con el agotamiento de los recursos energéticos.

CB4. Tratamiento de la información y competencia digital. Deben buscar, obtener, procesar y comunicar información sobre las fuentes de energía y el ahorro energético. CB5. Competencia social y ciudadana. El alumnado debe tomar decisiones cuando estén trabajando en grupo y elegir cómo comportarse tanto en las intervenciones en clase como durante el trabajo en grupo.

CB8. Autonomía e iniciativa personal. Deben cooperar y trabajar en equipo en la búsqueda de información y edición de los archivos podcasts. Así como dialogar y negociar la organización en la realización del trabajo en parejas.

\subsubsection{MATERIALES Y RECURSOS}

- Aula de informática.

- Ordenador, proyector, altavoces.

\subsubsection{DESCRIPCIÓN DE LA ACTIVIDAD}

\section{Parte}


Para comenzar el profesor o profesora reproducirá varias podcast sobre las fuentes de energía en clase de la siguiente web [25], en la que aparecen numerosos podcast en inglés, tanto de audio como de video, sobre la temática de Energía en general.

Se explicará a los alumnos y alumnas cómo sería el proceso para editar podcasts utilizando el programa Audacity [26], que es un editor de grabación y edición de sonido libre, de código abierto y multiplataforma.

\section{2a Parte}

Los alumnos y alumnas van a crear un programa sobre las fuentes de energía y el ahorro energético utilizando podcasts, las cuales van a ir subiendo al blog de la clase o centro, con un apartado denominado "Tu programa de Energía". Para ello, se van a dividir en grupos de dos o tres en caso de que el número de alumnos y alumnas del grupo/clase fuera impar.

Cada grupo va a editar al menos dos podcasts con entrevistas a sus familiares, vecinos, profesorados, alumnado del centro, etc. donde tienen que indagar sobre lo que saben de energía y la concienciación que existe sobre el ahorro energético. Por tanto tendrán que realizar preguntas como: ¿en qué acciones del día consumes energía? ¿Para qué usamos la energía?, ¿conoces alguna fuente de energía?, ¿de dónde proviene esa energía?, ¿quién controla la energía que consumimos?, ¿crees que podemos quedarnos algún día sin energía?, ¿qué acciones realizas en tu vida cotidiana para ahorrar energía? (preguntas planteadas según propuesta de García et al., 2007).

\section{3a Parte}

Después cada pareja va a investigar sobre un tipo de fuente de energía y vector energético y podrán elegir entre las siguientes:

- Fuentes de energía no renovables: carbón, petróleo, gas(natural y procedente del fracking), Nuclear (fusión y fisión)

- Fuentes de energía renovables: solar (térmica y fotovoltaica), eólica, biomasa, geotérmica, hidráulica y marítima (mareomotriz u otras).

- Vector energético: hidrógeno. 
Sobre cada una de las fuentes tendrán que buscar: definición, producción, transporte y distribución de la energía, usos, ventajas, inconvenientes, límites de las fuentes de energía no renovables y problemas ambientales relacionados con cada una. Tendrán que encontrar respuesta a todas las preguntas planteadas en la primera parte. Una vez tengan toda la información, van a editar el podcast. Para ello cada miembro de la pareja va a adquirir un rol, uno va a ser el entrevistador y el otro el entrevistado. Tendrán que crear algunas nuevas preguntas donde se incluya toda la información anteriormente mencionada.

\section{4a Parte}

Entre toda la clase van a crear una lista con acciones a lo largo del día que se pueden realizar para contribuir al ahorro energético. Tendrá que ser, al menos, una acción por alumno y alumna. Después van a elaborar un podcast entre todos y cuando lo estén editando cada alumno y alumna tendrá que decir su acción.

\section{DURACIÓN DE LA ACTIVIDAD}

En esta actividad no se puede decir una duración exacta en cuanto a sesiones excepto la primera parte que se realizaría en una sesión de 50 minutos. El resto de las partes se realizarían a lo largo del trimestre intentando escuchar los podcasts creados por los alumnos y alumnas en una sesión por semana. De esta forma cada semana dos o tres parejas tienen que tener preparados sus podcasts.

\subsubsection{ALTERNATIVAS}

\section{ALTERNATIVA 1}

La primera, tercera y cuarta parte se mantendría igual y se modificaría la segunda parte. En la que los alumnos y alumnas se van a dividir en grupos de 4 o 5 dependiendo del número de alumnado del grupo/clase. Van a entrevistar a varios expertos en energía utilizando podcats. Unos grupos entrevistarán a personal investigador de la universidad y otra parte de los grupos a personal de la Agencia Provincial de la Energía que se dedique al Plan Energético Provincial. Los alumnos y alumnas elaborarán un cuestionario en el que tendrán que indagar sobre las acciones 
que se han realizado o se deberían realizar para fomentar el ahorro energético de la ciudad. Después en clase se comentarán y compararán las respuestas de unos y otros. 


\section{CONCLUSIONES Y REFLEXIÓN FINAL}

En conclusión, con respecto a la parte del análisis de libros de texto he podido comprobar que, aunque en algún libro los contenidos son muy reducidos, la mayoría sí proporcionan información de casi todas las fuentes de energía, exceptuando el gas procedente del fracking (que no aparece en ninguno). Quizás esto se deba a que en España se está empezando a escuchar recientemente acerca de este tipo de fuente, y la mayoría de los libros datan del 2008. Algo parecido sucede con la energía del mar, que en casi todos los casos se limita a tratar la energía mareomotriz sin hacer mención alguna a otros tipos (undimotriz, de gradiente térmico, de salinidad, corrientes marinas o eólica marina). Esto me ha sorprendido, e incluso al contrario de lo que pensaba, no se limitan a dar una breve definición, sino que aportan más datos, como las aplicaciones, ventajas e inconvenientes, etc. Hay que destacar que en todos los libros aparecen uno o varios apartados dedicados a concienciar al alumnado en cuanto al ahorro energético.

Por otra parte, el resultado del análisis de las actividades concluye que en todos los libros predominan principalmente, los ejercicios, es decir, las respuestas se encuentran en el propio libro. Esto no facilita que el alumnado adquiera competencias (científica en este caso), ya que muy posiblemente se limite solo a copiar lo que está incluido en el libro, sin llevar a cabo tareas cognitivas que requieran una mayor demanda cognitiva (reflexión, transferencia o argumentación, Yus et al., 2013)

Por ello, en lo que respecta a la propuesta didáctica incluida en este TFM, se han planteado actividades de tipo experimental, creativo y de indagación, que puedan ser más útiles en el desarrollo de las competencias básicas, en especial de la de interacción y conocimiento del medio físico (o competencia científica).

Durante el diseño de éstas, he podido comprobar la dificultad que ello conlleva puesto que no se trataba solo de tener "buena imaginación" como a veces pensamos e inventar cada actividad. Sino que esta tenía que tener en cuenta los distintos elementos curriculares: ir acorde con los contenidos establecidos por la legislación, plantear los objetivos que se querían alcanzar y los criterios de evaluación con los que evaluar, así como, sobre todo intentar desarrollar competencias básicas. 
Otra de las dificultades que he tenido ha sido la de establecer la secuenciación de tareas dentro de cada actividad. Se tenían que desarrollar con una coherencia entre contenidos para que el aprendizaje del alumnado fuera lo más completo posible en cuanto a la temática de las fuentes energía y el ahorro energético.

Se ha intentado reflexionar y testar indirectamente si era factible la realización de las actividades propuestas, dado que desafortunadamente por razones de tiempo no se han podido implementar en el periodo de prácticas del Máster como era mi deseo original. Así, por ejemplo, en lo que se refiere a la búsqueda de información utilizando las TICs, he desarrollado la búsqueda personalmente para determinar si podrían existir dificultades en su realización. Esto ha tenido como consecuencia que en varias ocasiones tuviera que cambiar el desarrollo que había planteado inicialmente. En lo que se refiere a las experimentales he realizado dos de ellas, la chimenea solar y la destilación solar, siendo de mayor dificultad la primera por todo el proceso de elaboración que conlleva. El único inconveniente que he podido encontrar es el manejo de los materiales, ya que los alumnos y alumnas se encuentran en una edad en la que cualquier instrumento puede ser motivo de juego y en ocasiones esto pueda resultar peligroso. Por ello, he hecho hincapié y ha quedado reflejado como objetivo respetar las normas de seguridad en el aula.

Tengo que dejar constancia de que todo el planteamiento y desarrollo de las actividades requiere mucho tiempo para su elaboración. Al igual que también lo requiere para su realización en el aula.

Como pensamiento final tras la realización del TFM, puedo afirmar que considero que he aprendido bastante, ya que me ha permitido ponerme en situación de lo que voy a realizar como futura docente. Además, de ya disponer de un banco de actividades como recurso didáctico para mis clases en un futuro. 


\section{BIBLIOGRAFÍA}

Bañas, C., Mellado, V., y Ruiz, C. (2004). Los libros de texto y las ideas alternativas sobre la energía del alumnado de primer ciclo de educación secundaria obligatoria. Caderno Brasileiro de Ensino de Física, 21(3), 296-312.

Bolaño, J. J. (1997). Ingenios solares: Manual práctico para la construcción de aparatos sencillos relacionados con la energía solar Pamiela.

Çoker, B., Çatlıoğlu, H., y Birgin, O. (2010). Conceptions of students about renewable energy sources: A need to teach based on contextual approaches. Procedia-Social and Behavioral Sciences, 2(2), 1488-1492.

Consejería de Educación, Cultura y Deporte de la Junta de Andalucía (2007) Orden de 10 de agosto de 2007, por la que se desarrolla el currículo correspondiente a la Educación Secundaria Obligatoria en Andalucía. BOJA de 30 de agosto de 2007. Sevilla.

Doménech, J. L., Gil-Pérez, D., Gras, A., Guisasola, J., Martínez-Torregrosa, J., Salinas, J., Valdés, P. (2003). La enseñanza de la energía: Una propuesta de debate para un replanteamiento global. Caderno Brasileiro de Ensino de Física, 20(3), 285-311.

Fernández, I. M. S., y Vera, M. M. S. (2010). Aprendiendo en cualquier lugar: El podcast educativo. Pixel-Bit. Revista de Medios y Educación, (36), 125-139.

García, J. E., Rodríguez, F., Solís, M. C., y Ballenilla, F. (2007). Investigando el problema del uso de la energía. Investigación en la Escuela, 63, 29-45.

Gómez, J. M. B. (2006). Las energías renovables y el ahorro energético, desde el área de tecnología a la transversalidad e interdisciplinariedad. Sumuntán, (23), 185-206.

Herbel, M., Siracusa, P., y Raviolo, A. (2000). Desarrollo de actitudes hacia el cuidado de la energía: Experiencia en la formación de maestros. Enseñanza 
De Las Ciencias: Revista de Investigación y Experiencias Didácticas, 18(1), 7986.

Howarth, R. W., Ingraffea, A., y Engelder, T. (2011). Natural gas: Should fracking stop? Nature, 477(7364), 271-275.

Kishore, P., y Kisiel, J. (2013). Exploring high school students' perceptions of solar energy and solar cells. International Journal of Environmental \& Science Education, 8(3), 521-534.

Ministerio de Educación y Ciencia (2006) Ley Orgánica 2/2006, de 3 de mayo, de Educación. BOE de 4 de mayo de 2006. Madrid.

Ministerio de Educación y Ciencia (2007) Real Decreto 1631/2006 de 29 de diciembre, por el que se establecen las enseñanzas mínimas correspondientes a la Educación Secundaria Obligatoria. BOE del 5 de Enero de 2007. Madrid

Pedrinaci, E. (2011). El funcionamiento del planeta y la alfabetización en ciencias de la tierra. Alambique: Didáctica de las Ciencias Experimentales, 17(67), 10-19.

Perales Palacios, F. J., y Vílchez González, J. M. (2012). Libros de texto: Ni contigo ni sin ti tienen mis males remedio. Alambique: Didáctica de las Ciencias Experimentales, 18(70), 75-82.

Rodríguez, F. y García, J.E. (2007). ¿Qué dificultades encuentran los docentes para trabajar la energía en el ámbito de la educación ambiental formal? II Congreso Internacional de Educación, Energía y Desarrollo Sostenible. As Pontes de García Rodríguez 27, 28 y 29 de junio de 2007.

Sabariego, J. M. y Manzanares, M. (2006). Alfabetización científica. I congreso iberoamericano de ciencia tecnología, sociedad e innovación CTS+I. México D. F. 
Vázquez, A. (1998). Ideas del profesorado sobre la energía: uso, aplicaciones y tecnologías. Revista interuniversitaria de formación del profesorado, 32, 145158.

Yus Ramos, R., Gallardo Gil, M., Barquín Ruiz, J., Sepúlveda Ruiz, M. D. P., y Fernández Navas, M. (2013). La competencia científica y su evaluación. análisis de las pruebas estandarizadas de PISA. Revista de Educación, 360, 557-576.

Zyadin, A., Puhakka, A., Ahponen, P., Cronberg, T., y Pelkonen, P. (2012). School students' knowledge, perceptions, and attitudes toward renewable energy in Jordan. Renewable Energy, 45, 78-85. 


\section{WEBGRAFÍA}

[1] http://energy.gov/eere/education/energy-literacy-essential-principles-andfundamental-concepts-energy-education

[2] http://es.wikipedia.org/wiki/Torre_solar

[3]

http://www.consumer.es/web/es/medio_ambiente/energia_y_ciencia/2009/04/12/18 4638.php

[4] http://www.consumer.es/web/es/medio_ambiente/energia_y_ciencia/2009/04/12/18 4638.php

[5] http://www.terra.org/sites/default/files/bd_imagenes/0001535.gif

[6] http://www.terra.org/categorias/comunidad-guerrilla/chimenea-solar

[7] http://www.enviromission.com.au/EVM/content/home.html

[8] http://www.agenergia.org/index.php?section=65

[9] http://solarcooking.org/images/min7-flipped.jpg

[10] http://www.need.org/Files/curriculum/sciencefair/SolarDistillation.pdf

[11] http://espaciosustentable.com/wp-

content/uploads/2011/12/3190656535_b4ebb67a13.jpg

[12] https://www.youtube.com/watch?v=9dIVSYxtoZ8

[13]

http://www.who.int/mediacentre/news/notes/2013/sanitation_mdg_20130513/es/

[14] http://www.tendencias21.net/Mas-de-750-millones-de-personas-sin-acceso-alagua-potable-en-el-mundo_a32133.html

[15] http://www.zaragoza.es/ciudad/medioambiente/onu/es/detallePer_Onu?id=71

[16] http://info.elcorreo.com/suplemento-v/mirada-al-dia/?p=1251

[17] http://www.teorema.com.mx/wp-content/uploads/paises-desaconsuagu.jpg

[18] https://www.youtube.com/watch?v=LC8y8i2P1y0

[19] http://conflictosporrecursos.es/

[20] http://elmundo.com.sv/ninos-de-niger-faltan-a-la-escuela-para-buscar-agua 
[21] http://www.minetur.gob.es/energia/es-ES/Documents/Energia_en_Espana.pdf

[22] http://www.larutadelaenergia.org/fuentes/v2_home.asp?v=1\&b=100

[23]

http://www20.gencat.cat/docs/canviclimatic/Home/Politiques/Politiques\%20catalane s/La\%20mitigacio\%20del\%20canvi\%20climatic/Guia\%20de\%20calcul\%20demissions\%2 Ode\%20CO2/100916_Guia\%20practica\%20calcul\%20emissions_rev\%20ling_CA_ES.pdf

[24] http://alternativarenovable.blogspot.com.es/2010/10/fogon-mejorado.html

[25] http://sciencefriday.com/topics/energy.html\#page/bytopic/1

[26] http://audacity.sourceforge.net/?lang=es

[27] http://apps.who.int/iris/bitstream/10665/81245/1/9789241505390_eng.pdf [28]

https://www.google.com/publicdata/explore?ds=d5bncppjof8f9_\&ctype=I\&met_y=eg _use_pcap_kg_oe 
ANEXOS 


\section{ANEXO I: INSTRUMENTO DE ANÁLISIS Y RESULTADOS OBTENIDOS}

\section{Análisis de los Contenidos}

Tabla II. Datos generales de los libros de texto analizados.

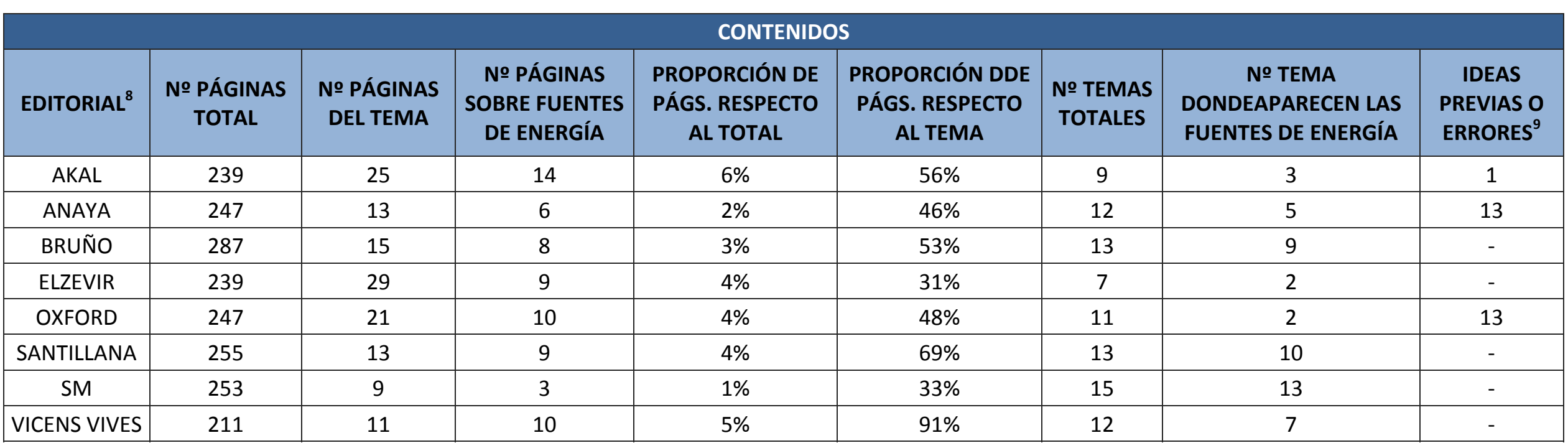

${ }^{8}$ Ver datos completos en el anexo III.

${ }^{9}$ Ver pp. 18-19. 
Tabla III. Análisis de contenidos - Valoración para fuentes de energía no renovables.

\begin{tabular}{|c|c|c|c|c|c|c|}
\hline \multirow{2}{*}{ EDITORIAL } & \multicolumn{3}{|c|}{ TIPOS FUENTES DE ENERGÍA NO RENOVABLESY VECTORES ENERGÉTICOS } \\
\cline { 2 - 7 } & \multirow{2}{*}{ CARBÓN } & \multirow{2}{*}{ PETRÓLEO } & \multicolumn{2}{c|}{ GAS } & \multicolumn{2}{c|}{ NUCLEAR } \\
\cline { 3 - 8 } & & & NATURAL CONVENCIONAL & PROCEDENTE FRACKING & FISIÓN & FUSIÓN \\
\hline AKAL & 2 & 2 & 2 & 0 & 2 & 1 \\
\hline ANAYA & 2 & 2 & 1 & 0 & 2 & 0 \\
\hline BRUÑO & 2 & 2 & 2 & 0 & 2 & 2 \\
\hline ELZEVIR & 2 & 2 & 2 & 0 & 2 & 0 \\
\hline OXFORD & 2 & 2 & 2 & 0 & 2 & 0 \\
\hline SANTILLANA & 2 & 2 & 2 & 0 & 2 & 0 \\
\hline SM & 2 & 2 & 2 & 0 & 2 & 0 \\
\hline VICENS VIVES & 2 & 2 & 2 & 0 & 2 & 0 \\
\hline
\end{tabular}

Tabla IV. Análisis de contenidos - Valoración para fuentes de energía renovables y vectores energéticos.

\begin{tabular}{|c|c|c|c|c|c|c|c|c|c|}
\hline \multicolumn{10}{|c|}{ CONTENIDOS } \\
\hline \multirow{3}{*}{ EDITORIAL } & \multicolumn{9}{|c|}{ TIPOS FUENTES DE ENERGÍARENOVABLES Y VECTORES ENERGÉTICOS } \\
\hline & \multicolumn{2}{|r|}{ SOLAR } & \multirow{2}{*}{ EÓLICA } & \multirow{2}{*}{ BIOMASA } & \multirow{2}{*}{ GEOTÉRMICA } & \multirow{2}{*}{ HIDRÁULICA } & \multicolumn{2}{|c|}{ MARÍTIMA } & \multirow{2}{*}{ HIDROGENO } \\
\hline & TÉRMICA & FOTOVOLTAICA & & & & & MAREOMOTRIZ & OTRAS & \\
\hline AKAL & 2 & 2 & 2 & 2 & 1 & 2 & 2 & 0 & 1 \\
\hline ANAYA & 1 & 1 & 2 & 1 & 1 & 2 & 1 & 1 & 1 \\
\hline BRUÑO & 1 & 1 & 1 & 1 & 1 & 1 & 1 & 0 & 0 \\
\hline ELZEVIR & 2 & 2 & 2 & 2 & 2 & 2 & 1 & 0 & 1 \\
\hline OXFORD & 2 & 2 & 2 & 2 & 2 & 2 & 2 & 1 & 0 \\
\hline SANTILLANA & 2 & 2 & 2 & 2 & 2 & 2 & 2 & 0 & 0 \\
\hline SM & 2 & 2 & 2 & 0 & 0 & 2 & 0 & 0 & 1 \\
\hline VICENS VIVES & 2 & 2 & 2 & 2 & 2 & 2 & 1 & 0 & 0 \\
\hline
\end{tabular}

${ }^{10}$ Valores: "0" No aparece, "1" Aparece (breve definición), "2" Aparece (aporta más datos). 
Tabla V. Análisis de contenidos - Crítica a los combustibles fósiles, límite del petróleo y concienciación.

\begin{tabular}{|c|c|c|c|c|c|c|c|}
\hline \multirow[b]{3}{*}{ EDITORIAL } & \multicolumn{6}{|c|}{ CONTENIDOS } & \multirow[b]{3}{*}{$\begin{array}{c}\text { APARTADO } \\
\text { DEDICADO A } \\
\text { CONCIENCIAR }^{14}\end{array}$} \\
\hline & \multirow{2}{*}{$\begin{array}{c}\text { ALUSIÓN AL } \\
\text { AHORRO } \\
\text { ENERGÉTICO }^{11}\end{array}$} & \multicolumn{3}{|c|}{ CRÍTICA A LOS COMBUSTIBLES FÓSILES ${ }^{12}$} & \multicolumn{2}{|c|}{ LÍMITE DEL PETRÓLEO ${ }^{13}$} & \\
\hline & & $\begin{array}{l}\text { "SE VAN A } \\
\text { AGOTAR" }\end{array}$ & "CONTAMINAN" & "EMITEN CO 2 " & $\begin{array}{c}\text { SE ESTABLECE FECHA } \\
\text { PARA EL AGOTAMIENTO } \\
\text { DELPETRÓLEO }\end{array}$ & $\begin{array}{l}\text { AÑOS QUE LE QUEDAN (En } \\
\text { caso } 1 \text { y } 2 \text { ) }\end{array}$ & \\
\hline AKAL & 1 & 1 & 1 & 1 & 0 & & 1 \\
\hline ANAYA & 1 & 1 & 1 & 1 & 1 & Se agota en 2200 & 1 \\
\hline BRUÑO & 1 & 1 & 1 & 1 & 1 & 5 décadas & 1 \\
\hline ELZEVIR & 1 & 1 & 1 & 1 & 0 & & 1 \\
\hline OXFORD & 1 & 1 & 1 & 1 & 0 & & 1 \\
\hline SANTILLANA & 1 & 1 & 1 & 1 & 0 & & 1 \\
\hline SM & 1 & 0 & 1 & 1 & 0 & & 1 \\
\hline VICENS VIVES & 1 & 1 & 1 & 1 & 2 & 100 años & 1 \\
\hline
\end{tabular}

\footnotetext{
${ }^{11}$ Valores:"0" No aparece, "1" Aparece.

${ }^{12}$ Valores:"0" No aparece, "1" Aparece. Ítems a considerar: "se van a agotar"; "contaminan"; "emiten CO a la atmósfera, que contribuye al calentamiento global".

${ }^{13}$ Valores:"0" No se establece, "1" Se establece de una manera absoluta, "2" Se establece de una manera condicionada, considerando las reservas actuales que puedan ser ampliadas.

${ }^{14}$ Valores: "0" No aparece, "1" Aparece.".
} 
Tabla VI. Análisis de contenidos - Resultados.

\begin{tabular}{|c|c|c|c|}
\hline \multicolumn{4}{|c|}{ CONTENIDOS } \\
\hline \multirow{2}{*}{ EDITORIAL } & $\begin{array}{l}\text { ÍNDICE SOBRE TIPOS DE } \\
\text { FUENTES (I1) }\end{array}$ & $\begin{array}{l}\text { ÍNDICE INFORMACIÓN } \\
\text { ADICIONAL(I2) }\end{array}$ & ÍNDICE GLOBAL CONTENIDOS (IGC) \\
\hline & $\begin{array}{c}\Sigma \text { (Valores tipos fuentes de } \\
\text { energía)/MAX. }{ }^{15}\end{array}$ & $\begin{array}{c}\sum \text { (Valores información } \\
\text { adicional)/MAX. }\end{array}$ & $I G C=(I 1+\mid 12) / 2$ \\
\hline AKAL & 0,79 & 0,71 & 0,75 \\
\hline ANAYA & 0,61 & 0,86 & 0,73 \\
\hline BRUÑO & 0,61 & 0,86 & 0,73 \\
\hline ELZEVIR & 0,75 & 0,71 & 0,73 \\
\hline OXFORD & 0,82 & 0,71 & 0,77 \\
\hline SANTILLANA & 0,79 & 0,71 & 0,75 \\
\hline SM & 0,57 & 0,57 & 0,57 \\
\hline VICENS VIVES & 0,75 & 1,00 & 0,88 \\
\hline
\end{tabular}

\footnotetext{
${ }^{15}$ Max. $=28$

${ }^{16}$ Max. $=7$
} 


\section{Análisis de las Imágenes}

Tabla VII. Análisis de imágenes - Proporción de imágenes sobre fuentes de energía.

\begin{tabular}{|c|c|c|c|c|c|}
\hline \multicolumn{6}{|c|}{ IMÁGENES } \\
\hline \multirow[t]{2}{*}{ EDITORIAL } & \multirow{2}{*}{$\begin{array}{l}\text { № IMÁGENES } \\
\text { TOTALES }\end{array}$} & \multicolumn{2}{|c|}{$\begin{array}{c}\text { IMÁGENESDEFUENTES DE ENERGÍA NO } \\
\text { RENOVABLES }\end{array}$} & \multicolumn{2}{|c|}{$\begin{array}{l}\text { IMÁGENESDEFUENTE DE ENERGÍA } \\
\text { RENOVABLES Y VECTORES ENERGÉTICO }\end{array}$} \\
\hline & & NÚMERO & PROPORCIÓN ${ }^{17}$ & NÚMERO & PROPORCIÓN \\
\hline AKAL & 13 & 5 & $38 \%$ & 8 & $62 \%$ \\
\hline ANAYA & 5 & 1 & $20 \%$ & 4 & $80 \%$ \\
\hline BRUÑO & 16 & 7 & $44 \%$ & 9 & $56 \%$ \\
\hline ELZEVIR & 23 & 2 & $9 \%$ & 21 & $91 \%$ \\
\hline OXFORD & 8 & 2 & $25 \%$ & 6 & $75 \%$ \\
\hline SANTILLANA & 11 & 3 & $27 \%$ & 8 & $73 \%$ \\
\hline SM & 4 & 1 & $25 \%$ & 3 & $75 \%$ \\
\hline VICENS VIVES & 11 & 5 & $45 \%$ & 6 & $55 \%$ \\
\hline
\end{tabular}

${ }^{17}$ Respecto al número de imágenes del tema. 
Tabla VIII. Análisis de imágenes - Valoración para fuentes de energía no renovables.

\begin{tabular}{|c|c|c|c|c|c|c|}
\hline \multirow{2}{*}{ EDITORIAL } & \multicolumn{9}{|c|}{ TIPOS DE FUENTES DE ENERGÍA Y VECTORES ENERGÉTICOS } \\
\cline { 2 - 8 } & \multirow{2}{*}{ CARBÓN } & \multirow{2}{*}{ PETRÓLEO } & \multicolumn{2}{c|}{ GAS } & \multicolumn{2}{c|}{ NUCLEAR } \\
\cline { 4 - 8 } & & & NATURAL CONVENCIONAL & PROCEDENTE FRAKING & FISIÓN & FUSIÓN \\
\hline AKAL & 1,1 & 1 & 0 & 0 & 2 & 2 \\
\hline ANAYA & 0 & 1 & 0 & 0 & 0 & 0 \\
\hline BRUÑO & 1,2 & 2,2 & 0 & 0 & 2 & 2,2 \\
\hline ELZEVIR & 0 & 1 & 0 & 0 & 1 & 0 \\
\hline SANTILLANA & 1 & 0 & 1 & 0 & 2 & 0 \\
\hline SM & 0 & 0 & 2 & 0 & 0 & 0 \\
\hline VICENS VIVES & 1 & 1 & 1,1 & 0 & 1 & 0 \\
\hline OXFORD & 0 & 0 & 0 & 0 & 1,1 & 0 \\
\hline
\end{tabular}

Tabla IX. Análisis de imágenes - Valoración para fuentes de energía renovables y vectores energéticos.

\begin{tabular}{|c|c|c|c|c|c|c|c|c|c|}
\hline \multicolumn{10}{|c|}{ IMÁGENES } \\
\hline \multirow{3}{*}{ EDITORIAL } & \multicolumn{9}{|c|}{ TIPOS DE FUENTES DE ENERGÍA Y VECTORES ENERGÉTICOS } \\
\hline & \multicolumn{2}{|r|}{ SOLAR } & \multirow{2}{*}{ EÓLICA } & \multirow{2}{*}{ BIOMASA } & \multirow{2}{*}{ GEOTÉRMICA } & \multirow{2}{*}{ HIDRÁULICA } & \multicolumn{2}{|c|}{ MARÍTIMA } & \multirow{2}{*}{ HIDRÓGENO } \\
\hline & TÉRMICA & FOTOVOTÁICA & & & & & MAREOMOTRÍZ & OTRAS & \\
\hline AKAL & 1,2 & 1 & 1 & 1,1 & 0 & 1 & 2 & 0 & 0 \\
\hline ANAYA & 2 & 1 & 0 & 0 & 0 & 1 & 0 & 0 & 2 \\
\hline BRUÑO & 1,2 & 2 & 1 & 1,2 & 1 & 2 & 2 & 0 & 0 \\
\hline ELZEVIR & $1,2,1,1,1$ & $1,1,1,1$ & $1,1,1$ & $1,1,1,1,1$ & 1 & 1 & 0 & 0 & 1,1 \\
\hline OXFORD & 1 & 1 & 1 & 1 & 1 & 1 & 0 & 0 & 0 \\
\hline SANTILLANA & 0 & 1,1 & 2,1 & 1 & 1 & 2 & 2 & 0 & 0 \\
\hline SM & 2 & 1 & 0 & 0 & 0 & 0 & 0 & 0 & 1 \\
\hline VICENS VIVES & 1 & 1 & 1 & 1,1 & 1 & 0 & 0 & 0 & 0 \\
\hline
\end{tabular}

${ }^{18}$ Valores: "0" No aparece, "1", Aparece (ilustrativa), "2" Aparece (explicativa). 
Tabla X. Análisis de imágenes - Índices intermedios.

\begin{tabular}{|c|c|c|c|c|c|c|c|c|c|c|}
\hline \multicolumn{11}{|c|}{ IMÁGENES } \\
\hline \multirow{2}{*}{ EDITORIAL } & \multicolumn{5}{|c|}{ IMÁGENES FUENTES DE ENERGÍA NO RENOVABLES } & \multicolumn{5}{|c|}{$\begin{array}{l}\text { IMÁGENES FUESTES DE ENERGÍA RENOVABLES Y VECTORES } \\
\text { ENERGÉTICOS }\end{array}$} \\
\hline & $\begin{array}{l}\text { NÚMERO } \\
\text { TOTAL }\end{array}$ & "1" & $\begin{array}{l}\text { PROPORCIÓN } \\
\text { "1" }\end{array}$ & "2" & $\begin{array}{l}\text { PROPORCIÓN } \\
\text { "2" }\end{array}$ & NÚMERO TOTAL & "1" & PROPORCIÓN "1" & "2" & PROPORCIÓN "2" \\
\hline AKAL & 5 & 3 & 0,60 & 2 & 0,40 & 8 & 6 & 0,75 & 2 & 0,25 \\
\hline ANAYA & 1 & 1 & 1,00 & 0 & 0,00 & 4 & 2 & 0,50 & 2 & 0,50 \\
\hline BRUÑO & 7 & 1 & 0,14 & 6 & 0,86 & 9 & 4 & 0,44 & 5 & 0,56 \\
\hline ELZEVIR & 2 & 2 & 1,00 & 0 & 0,00 & 21 & 20 & 0,95 & 1 & 0,05 \\
\hline OXFORD & 2 & 2 & 1,00 & 0 & 0,00 & 6 & 6 & 1,00 & 0 & 0,00 \\
\hline SANTILLANA & 3 & 2 & 0,67 & 1 & 0,33 & 8 & 5 & 0,63 & 3 & 0,38 \\
\hline SM & 1 & 0 & 0,00 & 1 & 1,00 & 3 & 2 & 0,67 & 1 & 0,33 \\
\hline VICENS VIVES & 5 & 5 & 1,00 & 0 & 0,00 & 6 & 6 & 1,00 & 0 & 0,00 \\
\hline
\end{tabular}


Tabla XI. Análisis de imágenes - Resultados.

\begin{tabular}{|c|c|c|c|c|c|c|c|}
\hline \multicolumn{8}{|c|}{ IMÁGENES } \\
\hline \multirow[b]{3}{*}{ EDITORIAL } & \multirow{2}{*}{\multicolumn{3}{|c|}{$\begin{array}{l}\text { ÍNDICE NO RENOVABLES } \\
\text { Índice intermedio } 1 \text { (J1) }\end{array}$}} & \multirow{2}{*}{\multicolumn{3}{|c|}{$\begin{array}{l}\text { ÍNDICE RENOVABLES } \\
\text { Índice intermedio 2(J2) }\end{array}$}} & \multirow{3}{*}{$\begin{array}{l}\text { ÍNDICE GLOBAL } \\
\text { IMÁGENES (IGI) } \\
\begin{array}{c}\text { IGI }=\mathrm{J} 1 * 0,4+ \\
\mathrm{J} 2 * 0,6\end{array}\end{array}$} \\
\hline & & & & & & & \\
\hline & $A=\left\{\begin{aligned} N / 20 ; & N \leq 20 \\
1 ; & N>20\end{aligned}\right.$ & $\begin{array}{c}B= \\
\text { Proporción } \\
\text { valor "2" }\end{array}$ & $\begin{array}{c}\mathrm{J} 1=\mathrm{A} * 0,7+ \\
\mathrm{B} * 0,3\end{array}$ & $A=\left\{\begin{aligned} N / 20 ; & N \leq 20 \\
1 ; & N>20\end{aligned}\right.$ & $\begin{array}{c}\text { B }= \\
\text { Proporción } \\
\text { valor "2" }\end{array}$ & $\mathrm{J} 2=\mathrm{A} * 0,7+\mathrm{B}^{*} 0,3$ & \\
\hline AKAL & 0,25 & 0,40 & 0,30 & 0,40 & 0,25 & 0,36 & 0,33 \\
\hline ANAYA & 0,05 & 0,00 & 0,04 & 0,20 & 0,50 & 0,29 & 0,19 \\
\hline BRUÑO & 0,35 & 0,86 & 0,50 & 0,45 & 0,56 & 0,48 & 0,49 \\
\hline ELZEVIR & 0,10 & 0,00 & 0,07 & 1,00 & 0,05 & 0,71 & 0,46 \\
\hline OXFORD & 0,10 & 0,00 & 0,07 & 0,30 & 0,00 & 0,21 & 0,15 \\
\hline SANTILLANA & 0,15 & 0,33 & 0,21 & 0,40 & 0,38 & 0,39 & 0,32 \\
\hline SM & 0,05 & 1,00 & 0,34 & 0,15 & 0,33 & 0,21 & 0,26 \\
\hline VICENS VIVES & 0,25 & 0,00 & 0,18 & 0,30 & 0,00 & 0,21 & 0,20 \\
\hline
\end{tabular}

${ }^{1} \mathrm{~N}=$ Número de imágenes del tema. 


\section{Análisis de las Actividades}

Tabla XII. Análisis de actividades - Proporción de actividades sobre fuentes de energía.

\begin{tabular}{|c|c|c|c|}
\hline \multicolumn{5}{|c|}{ ACTIVIDADES } \\
\hline EDITORIAL & $\begin{array}{c}\text { No ACTIVIDADES } \\
\text { TOTALES DEL TEMA }\end{array}$ & $\begin{array}{c}\text { No ACTIVIDADES SOBRE } \\
\text { FUENTES DE ENERGÍA Y } \\
\text { AHORRO ENERGÉTICO }\end{array}$ & $\begin{array}{c}\text { PROPORCIÓN DE ACTIVIDADES } \\
\text { SOBRE FUENTES DE ENERGÍA Y } \\
\text { AHORRO ENERGÉTICO }\end{array}$ \\
\hline AKAL & 69 & 38 & 0,55 \\
\hline ANAYA & 71 & 40 & 0,56 \\
\hline BRUÑO & 46 & 28 & 0,61 \\
\hline ELZEVIR & 61 & 19 & 0,31 \\
\hline OXFORD & 55 & 10 & 0,18 \\
\hline SANTILLANA & 72 & 51 & 0,71 \\
\hline SM & 51 & 16 & 0,31 \\
\hline VICENS VIVES & 36 & 36 & 1,00 \\
\hline
\end{tabular}


Tabla XIII. Análisis de actividades - Proporción de actividades de tipo lápiz/papel vs. experimentales.

\begin{tabular}{|c|c|c|c|c|c|}
\hline \multirow{2}{*}{ EDITORIAL } & \multirow{2}{*}{$\begin{array}{c}\text { No ACTIVIDADES SOBRE } \\
\text { FUENTES DE ENERGÍA Y } \\
\text { AHORRO ENERGÉTICO }\end{array}$} & \multicolumn{3}{|c|}{ TIPO DE ACTIVIDADES } \\
\cline { 3 - 6 } & & NÚMERO & PROPORCIÓN & NÚMERO & PROPORCIÓN \\
\cline { 3 - 6 } & 38 & 38 & 1,00 & 0 & 0,00 \\
\hline AKAL & 40 & 40 & 1,00 & 0 & 0,00 \\
\hline ANAYA & 28 & 27 & 0,96 & 1 & 0,04 \\
\hline BRUÑO & 19 & 18 & 0,95 & 1 & 0,05 \\
\hline ELZEVIR & 10 & 10 & 1,00 & 0 & 0,00 \\
\hline OXFORD & 51 & 50 & 0,98 & 1 & 0,02 \\
\hline SANTILLANA & 16 & 16 & 1,00 & 0 & 0,00 \\
\hline SM & 36 & 36 & 1,00 & 0 & 0,00 \\
\hline
\end{tabular}

Tabla XIV. Análisis de actividades - Proporción de actividades de tipo abierto vs. cerrado.

\begin{tabular}{|c|c|c|c|c|c|}
\hline \multirow{2}{*}{ EDITORIAL } & \multirow{2}{*}{\begin{tabular}{c} 
No ACTIVIDADES SOBRE \\
FUENTES DE ENERGÍA Y \\
\cline { 3 - 6 }
\end{tabular}} & \multicolumn{5}{|c|}{ TIPO DE ACTIVIDADES } \\
\cline { 3 - 6 } & AHORRO ENERGÉTICO & SOLUCIÓN ABIERTA & \multicolumn{2}{|c|}{ SOLUCIÓN CERRADA } \\
\cline { 3 - 6 } & 38 & 18 & 0,47 & 20 & 0,53 \\
\hline AKAL & 40 & 12 & 0,30 & 28 & 0,70 \\
\hline ANAYA & 28 & 0 & 0,00 & 28 & 1,00 \\
\hline BRUÑO & 19 & 10 & 0,53 & 9 & 0,47 \\
\hline ELZEVIR & 10 & 4 & 0,40 & 6 & 0,60 \\
\hline OXFORD & 51 & 10 & 0,20 & 41 & 0,80 \\
\hline SANTILLANA & 16 & 7 & 0,44 & 9 & 0,56 \\
\hline SMM & 36 & 13 & 0,36 & 23 & 0,64 \\
\hline VICENS VIVES & & & PROPORCIÓN & NÚMERO & PROPORCIÓN \\
\hline
\end{tabular}


Tabla XV. Análisis de actividades - Proporción de actividades de tipo ejercicio, indagación y creativas.

\begin{tabular}{|c|c|c|c|c|c|c|c|}
\hline \multicolumn{8}{|c|}{ ACTIVIDADES } \\
\hline \multirow{3}{*}{ EDITORIAL } & \multirow{3}{*}{$\begin{array}{l}\text { № ACTIVIDADES SOBRE } \\
\text { FUENTES DE ENERGÍA Y } \\
\text { AHORRO ENERGÉTICO }\end{array}$} & \multicolumn{6}{|c|}{ TIPO DE ACTIVIDADES } \\
\hline & & \multicolumn{2}{|c|}{ EJERCICIOS (RESPUESTA LIBRO) } & \multicolumn{2}{|c|}{ INDAGACIÓN } & \multicolumn{2}{|c|}{ CREATIVAS } \\
\hline & & NÚMERO & PROPORCIÓN & NÚMERO & PROPORCIÓN & NÚMERO & PROPORCIÓN \\
\hline AKAL & 38 & 24 & 0,63 & 11 & 0,29 & 3 & 0,08 \\
\hline ANAYA & 40 & 28 & 0,70 & 12 & 0,30 & 0 & 0,00 \\
\hline BRUÑO & 28 & 24 & 0,86 & 2 & 0,07 & 2 & 0,07 \\
\hline ELZEVIR & 19 & 9 & 0,47 & 8 & 0,42 & 2 & 0,11 \\
\hline OXFORD & 10 & 5 & 0,50 & 4 & 0,40 & 1 & 0,10 \\
\hline SANTILLANA & 51 & 33 & 0,65 & 14 & 0,27 & 4 & 0,08 \\
\hline SM & 16 & 7 & 0,44 & 6 & 0,38 & 3 & 0,19 \\
\hline VICENS VIVES & 36 & 22 & 0,61 & 10 & 0,28 & 4 & 0,11 \\
\hline
\end{tabular}


Tabla XVI. Análisis de actividades - Resultados.

\begin{tabular}{|c|c|c|c|c|c|}
\hline \multirow[b]{2}{*}{ EDITORIAL } & EXPERIMENTALES & SOLUCIÓN ABIERTA & INDAGACIÓN Y CREATIVOS & ÍNDICE NÚMERO DE & ÍNDICE GLOBAL \\
\hline & K1= proporción & K2 = proporción & 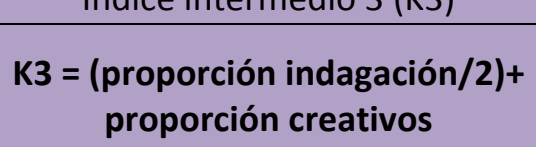 & $K=\left\{\begin{aligned} \boldsymbol{N} / \mathbf{5 0} ; & N \leq 50 \\
\mathbf{1} ; & N>50\end{aligned}\right.$ & $I G A=(K+K 1+K 2+K 3) / 4$ \\
\hline AKAL & 0,00 & 0,47 & 0,22 & 0,76 & 0,36 \\
\hline ANAYA & 0,00 & 0,30 & 0,15 & 0,80 & 0,31 \\
\hline BRUÑO & 0,04 & 0,00 & 0,11 & 0,56 & 0,18 \\
\hline ELZEVIR & 0,05 & 0,53 & 0,32 & 0,38 & 0,32 \\
\hline OXFORD & 0,00 & 0,40 & 0,30 & 0,20 & 0,23 \\
\hline SANTILLANA & 0,02 & 0,20 & 0,22 & 1,00 & 0,36 \\
\hline SM & 0,00 & 0,44 & 0,38 & 0,32 & 0,28 \\
\hline VICENS VIVES & 0,00 & 0,36 & 0,25 & 0,72 & 0,33 \\
\hline
\end{tabular}

${ }^{2} \mathrm{~N}=$ Número de actividades del tema. 


\section{Análisis Global}

Tabla XVII. Análisis de libros de texto - Índice global.

\begin{tabular}{|c|c|c|c|c|}
\hline \multirow{2}{*}{ EDITORIAL } & $\begin{array}{c}\text { ÍNDICE GLOBAL } \\
\text { CONTENIDOS (IGC) }\end{array}$ & $\begin{array}{c}\text { ÍNDICE GLOBAL } \\
\text { IMÁGENES (IGI) }\end{array}$ & $\begin{array}{c}\text { ÍNDICE GLOBAL } \\
\text { ACTIVIDADES (IGA) }\end{array}$ & $\begin{array}{c}\text { ÍNDICE GLOBAL } \\
\text { IGC*O,4 + IGI*0,1 + } \\
\text { IGA*0,5 }\end{array}$ \\
\hline AKAL & 0,75 & 0,33 & 0,36 & $\mathbf{0 , 5 1}$ \\
\hline ANAYA & 0,73 & 0,19 & 0,31 & $\mathbf{0 , 4 7}$ \\
\hline BRUÑO & 0,73 & 0,49 & 0,18 & $\mathbf{0 , 4 3}$ \\
\hline ELZEVIR & 0,73 & 0,46 & 0,32 & $\mathbf{0 , 5 0}$ \\
\hline OXFORD & 0,77 & 0,15 & 0,23 & $\mathbf{0 , 4 4}$ \\
\hline SANTILLANA & 0,75 & 0,32 & 0,36 & $\mathbf{0 , 5 1}$ \\
\hline SMM & 0,57 & 0,26 & 0,28 & $\mathbf{0 , 3 9}$ \\
\hline VICENS VIVES & 0,88 & 0,2 & 0,33 & $\mathbf{0 , 5 4}$ \\
\hline
\end{tabular}




\title{
ANEXO II: RECURSOS DEL BANCO DE ACTIVIDADES
}

\section{RECURSOS ACTIVIDAD 7.4. ¿RECURSO ENERGÉTICO ES IGUAL A CONFLICTO?}

Para realizar la primera parte de la actividad sobre los conflictos por recursos energéticos y la tercera parte sobre los conflictos hídricos podrán obtener información de la web [17].

Además, para la búsqueda de información de la tercera parte sobre la situación actual del agua en el mundo, una de las fuentes que pueden utilizar es el informe titulado "Progress on Sanitation and Drinking-Water 2013" [27].

Noticia completa que se presenta en la cuarta parte de esta actividad, procedente de [20].

\section{"Niños de Níger faltan a la escuela para buscar agua"}

\author{
Martes 5, junio 2012 | 8:13 pm
}

"Níger es el penúltimo país en el Índice de Desarrollo Humano de Naciones Unidas, y está sujeto a sequías y casi hambrunas.

Níger.- Las guerras impiden que los niños vayan a la escuela. También las enfermedades. Pero en Níger, un país calcinado por el sol donde las sequías ocurren con alarmante frecuencia, un impedimento importante para la educación es la sed y el largo trecho que se tiene que recorrer para saciarla.

La jornada escolar ya había empezado en una mañana reciente mientras una procesión de niños pequeños en burros, todos de edad escolar, se abrían camino sobre un campo arenoso, uniéndose a otros jovencitos reunidos con sus animales en torno a hoyos profundos en el suelo.

Como la baja precipitación pluvial ha secado al campo, la búsqueda de agua se ha vuelto cada vez más difícil. La tarea de conseguir agua frecuentemente recae en los niños de Níger, algunos de apenas 10 u 11 años de edad. A lomos de burros se alejan hasta ocho kilómetros de la localidad, con gigantescas garrafas de plástico de la mitad de su altura atadas a los costados de los animales. Entre más trabajan, más se vacían las aulas del este de Níger.

"Mis padres me enviaron", dijo Sani Abdu, de 11 años, un niño con una playera azul, entornando un ojo bajo el brillante sol matutino. La hinchazón había cerrado el otro. Serían las 10 de la mañana antes de que regresara de los lodosos pozos en Baban Tapki, a orillas de Zinder, a su escuela rural, con dos horas de retraso. Envidiaba a los que no tenían que lidiar con el "deber del agua", o "corvee de l'eau", como se le llama aquí: el recorrido, y luego hacer descender los tazones o cubetas, con cuerdas, en los pozos profundos. Es una tarea laboriosa y traicionera, pues en ocasiones los niños pierden pisada y caen al interior. 
"Los otros están más avanzados que yo, pero tengo que conseguir el agua", dijo Sani de sus compañeros de clases que escapan de la tarea y llegan a la escuela a tiempo.

Níger es el penúltimo país en el Índice de Desarrollo Humano de Naciones Unidas, y está sujeto a sequías y casi hambrunas. En la última década, ha habido tres graves periodos de escasez de alimentos relacionados con la baja precipitación pluvial y ataques de insectos, y este año quizá un tercio de la población está enfrentando la inanición.

Un déficit en la precipitación pluvial el año pasado -la corta temporada de lluvias terminó antes, y las lluvias fueron raras e irregulares-dejó a la tierra sin los estanques superficiales de los que dependen muchos de los 17 millones de habitantes de Níger, la mayoría agricultores de subsistencia. Casi un tercio de la población enfrenta ahora un déficit de alimentos. Pero más inmediatamente, el pueblo debe tener agua, y como los buenos pozos son cada vez más difíciles de encontrar, la búsqueda de los mismos recae en la siguiente generación.

En los distritos rurales alrededor de Zinder, la segunda ciudad más grande de Níger, dicen funcionarios, entre un tercio y la mitad de los estudiantes han abandonado las aulas, que no son más que sencillas chozas de carrizos secos plantados en la arena. "Es el agua lo que los mantiene alejados de la escuela", dijo Salissou Sahirou, un funcionario de educación en Baban Tapki. "Todas las escuelas aquí están paralizadas", dijo Sylvain Musafiri, un destacado funcionario de Naciones Unidas en Zinder.

En aulas improvisadas que se alzan sobre los matorrales del desierto en Garin Gona, casi todos los niños levantaron la mano cuando su maestro preguntó cuántos habían llegado tarde debido al deber del agua.

Oumaraou Lawali, de 11 años de edad, abrió mucho los ojos y explicó cómo se había despertado a las 4:30 de la mañana para caminar cinco kilómetros en busca de agua; posteriormente, después de clases, repetiría el viaje. "En las noches, estoy cansado", dijo. "Agotado".

A menudo, dijo el maestro, Maman Boukari, los niños se duermen ante sus ojos.

La búsqueda de agua es una constante, en años buenos y malos, ya que $80 \%$ de la población no tiene agua corriente. Pero este año, "es peor, y no está mejorando", dijo otro maestro, Barki Hima. "Es el sol, siempre el sol. Este año, realmente, es difícil. Los niños están llegando dos horas tarde".

En Zinder, una polvorienta metrópoli de unos 350,000 habitantes cerca de la frontera con Nigeria, hubo disturbios esta primavera por la falta de agua. Residentes enojados han quemado neumáticos y erigido barricadas de piedras en las calles arenosas de esta ciudad histórica, anteriormente la capital de un poderoso sultanato Hausa y posteriormente de la colonia francesa que se convirtió en Níger. A fines de marzo, las oficinas de la centímetro estatal del agua fueron atacadas. 
En las esquinas con fuentes públicas, el agua es embotellada y vendida, causando que las fuentes se sequen como todo lo demás. En una tarde reciente, hombres y niños estaban recolectando agua de un sucio lago de agua de lluvia a orillas de la ciudad.

A todos les preocupa la falta de agua, pero son los niños, principalmente las niñas, las encargadas de buscarla. Los más pobres de los pobres envían a sus hijos. También sus líderes, que están igual de sedientos y desesperados por el agua todos los días.

"Son mis hijos quienes consiguen el agua", dijo Titi Malla Adamou, el jefe de la aldea de Tsoungounia, donde camellos que cargan garrafas vagan por la orilla de la aldea en medio de grupos de burros montados por niños. "Este es un problema para todos, desde los más pequeños hasta los más grandes".

Pocos cuestionan este sistema en un país con una de las tasas de natalidad más altas del mundo y una de las tasas de crecimiento poblacional más rápidas, donde las mujeres tienen alrededor de siete hijos en promedio.

Con tanta escasez en Níger, que se asienta mayormente en el Sahara, hay una abundancia de niños. "Tuve que mandar a mis propios hijos a buscar agua", dijo Ado Louche, un destacado funcionario escolar para la región de Zinder.

Con cada vez más niños en busca de agua, su futuro se vuelve más precario. Después de un año de escolaridad en una aldea en las afueras de Zinder, Zuero Mutari, una jovencita de 13 años de edad, tuvo que desertar hace nueve años durante una sequía anterior para buscar agua. La escuela "me interesa, porque veo a otros ir", dijo Zuero, quien conduce un vagón de ganado cargado de garradas y pasa su día buscando agua.

En los pozos de Baban Tapki, tres niñitas, que son hermanas, dijeron que ninguna de ellas había asistido a la escuela. "Estamos inscritas, pero no vamos", dijo Maria Bugagi, de 12 años de edad, junto a sus hermanas menores Balik y Rahila. "Tenemos que buscar agua". Las largas búsquedas de agua incluyen el temor de una agresión sexual.

"Para tener agua, debemos movilizar a nuestros hijos", dijo Yunfa Adaga, lamentando la práctica. "Nuestros hijos llegan tarde a la escuela. Por ello, no están aprendiendo". Adaga administraba una fuente pública en Zinder, pero se ha secado. "Vivimos y dormimos con este problema del agua", dijo. "Nos atormenta". 


\section{RECURSOS ACTIVIDAD 7.5. ¿CUÁNTA ENERGÍA HAY EN LA COMIDAD DE MARTA?}

La presentación de la tercera parte puede seguir este guión:

- ¿Qué acciones realizas a lo largo del día que requieren energía?

- ¿De qué fuentes procede la energía que consumes? Relaciónalo con el apartado anterior.

- ¿Conoces la cantidad de energía que usamos en España? Realiza una búsqueda en Internet, y representa los datos.

- ¿Cuáles son las principales fuentes que se utilizan en España? Antes de buscar la pregunta, intenta responder dando tu opinión.

- ¿Cómo se obtiene esa energía? Busca información sobre la producción, transporte y distribución.

- ¿Crees que todos los recursos energéticos que se utilizan para producir la energía que tú consume provienen de España? Realiza una búsqueda en Internet.

\section{- Nota: aporta datos, gráficos y tablas.}

Para buscar la información que se les pide en la tercera y cuarta partes de la actividad, una de las fuentes que podrían utilizar es el informe titulado "La Energía en España 2012" [21].

Estos son ejemplos de gráficas procedentes del Banco Mundial en el Google Data Public Explorer [28], las cuales pueden presentar para realizar la cuarta parte de esta actividad. En esta misma página pueden encontrar más información.

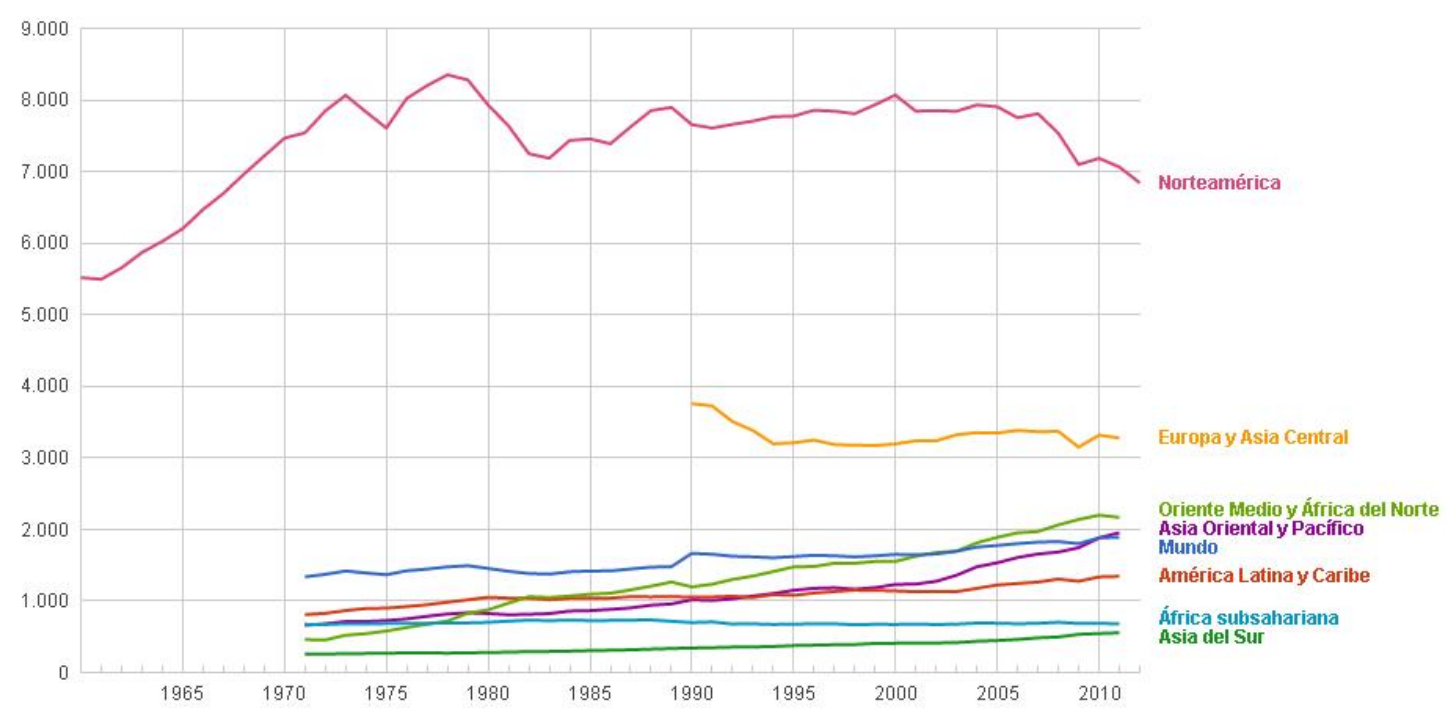

Fig.36. Uso energético per cápita. 




Fig.37. Consumo de energía de combustibles fósiles (\% del total).

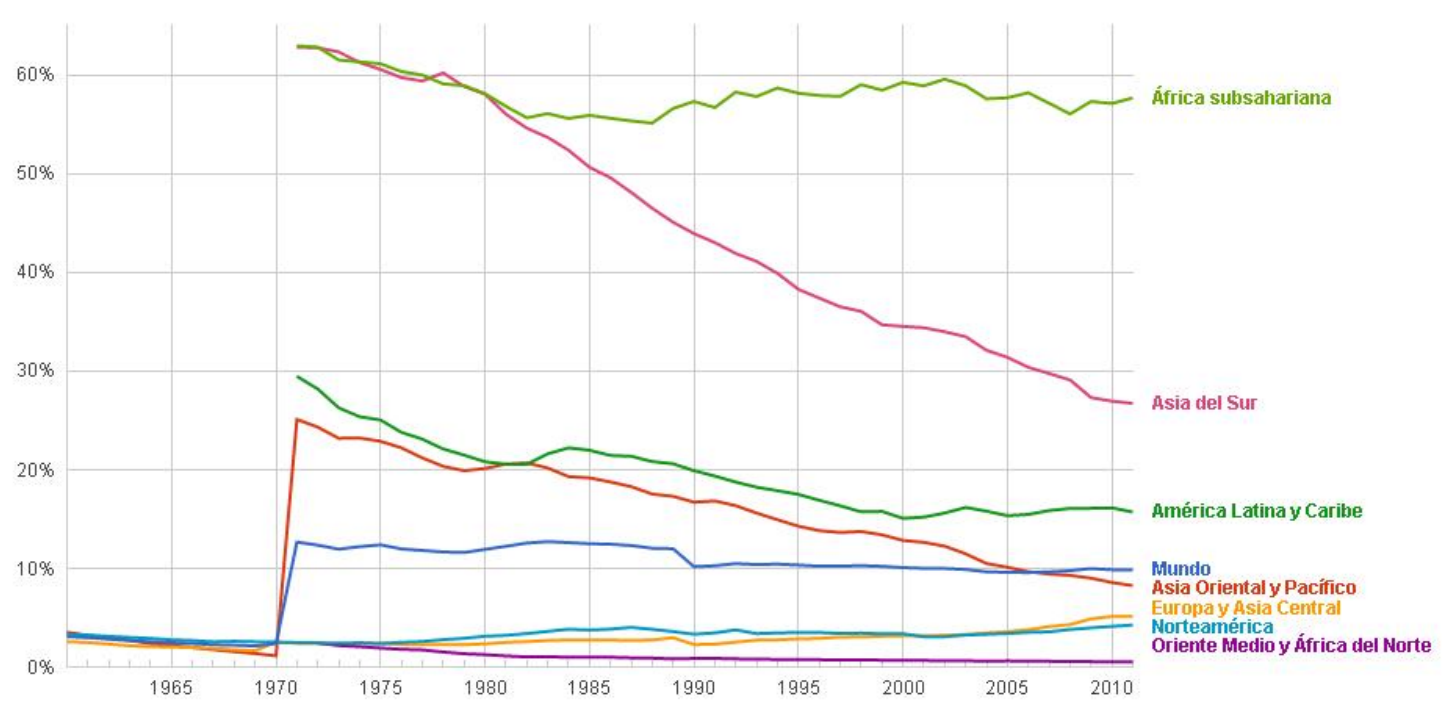

Fig.38. Combustibles renovables y residuos (\% del total de la energía). 


\section{ANEXO III: REFERENCIAS DE LOS LIBROS DE TEXTO}

Balibrea López, S., Reyes Camacho, M., Álvarez Alcántara, A., Sáez Fernández, A., Vílchez González, J.M. (2008). Ciencias de la naturaleza. 2eSO. Madrid: Anaya.

Barrio Gómez de Agüero, J., Bermúdez Menese, M.L., Faure López, A., Gómez Esteban, M.F., Bárcena Rodríguez, J. (2012). Ciencias de la naturaleza. 2ํESO Andalucía. Madrid: Oxford.

Fernández Esteban, M.A., Martínez de Murguía Larrechi, M.J., Mingo Zapatero, B., Rodríguez Bernabé, R., Torres Lobejón, M.D. (2008). Natura 2: Ciencias de la Naturaleza. Barcelona: Vicens Vives.

Gil, C., Pedrinaci, E., Carrión, F., Jiménez, J.D. (2008). Ciencias de la naturaleza, Entorno, 2 ESO. Madrid: Sm.

Hierrezuelo Moreno, J., Bullejos de la Higuera, J., Carmona García-Galán, A., Molina González, E., Montero Moreno, A. Mozas Arroyo, T., Ruiz Rodríguez, G., Sampedro Villasán, C., del Valle Nuñez, V., Yus Ramos, R. (2008). Ciencias de la naturaleza. 2을 ESO Torre del Mar Málaga: Elzevir.

Madrid Rangel, M.A., Brandi Fernández, A. (2008). Ciencias de la naturaleza. 2o ESO Andalucía. Madrid: Santillana.

Panadero Cuartero, J.E., Lozano Montero, A., Argüello González, J.A., Olazábal Flórez, A., Bayón Fernández, A.M., Bayón Fernández, A., Fuente Flórez, M.R. (2008). Ciencias de la Naturaleza. 2ํㅗ. Andalucía. Madrid: Bruño.

Villarán Adánez, A., Codes Valcarce, R., Callejo Fernández, S. (2008). Ciencias de la naturaleza: 2o ESO. Madrid: Akal. 